\title{
REFERENCE MATERIAL SYSTEMS: A SOURCEBOOK FOR MATERIAL ASSESSMENT
}

\author{
N. BhaGat, Editor
}

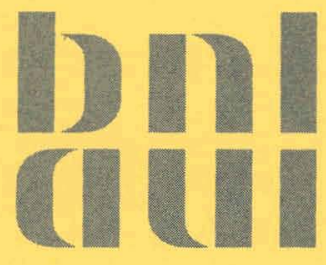

December 1976

Prepared for the

OFFICE OF THE ASSISTANT ADMINISTRATOR FOR PLANNING, ANALYSIS, AND EVALUATION UNITED STATES ENERGY RESEARCH AND DEVELOPMENT ADMINISTRATION

By the

TECHNOLOGY ASSESSMENT GROUP

NATIONAL CENTER FOR ANALYSIS OF ENERGY SYSTEMS

BROOKHAVEN NATIONAL LABORATORY ASSOCIATED UNIVERSITIES, INC.

UNDER CONTRACT NO. EY-76-C-02-0016 WITH THE

UNITED STATES ENERGY RESEARCH AND DEVELOPMENT ADMINISTRATION 


\section{DISCLAIMER}

This report was prepared as an account of work sponsored by an agency of the United States Government. Neither the United States Government nor any agency Thereof, nor any of their employees, makes any warranty, express or implied, or assumes any legal liability or responsibility for the accuracy, completeness, or usefulness of any information, apparatus, product, or process disclosed, or represents that its use would not infringe privately owned rights. Reference herein to any specific commercial product, process, or service by trade name, trademark, manufacturer, or otherwise does not necessarily constitute or imply its endorsement, recommendation, or favoring by the United States Government or any agency thereof. The views and opinions of authors expressed herein do not necessarily state or reflect those of the United States Government or any agency thereof. 


\section{DISCLAIMER}

Portions of this document may be illegible in electronic image products. Images are produced from the best available original document. 
BNL 50609

(Materials - TID-4500)

\title{
REFERENCE MATERIAL SYSTEMS: A SOURCEBOOK FOR MATERIAL ASSESSMENT
}

\author{
N. BHAGat, Editor
}

Contributors:

N. Bhagat

K.C. Hoffman

L. Briggs*

S. Saneski

F. Drysdale

R. Tessmer

D. Hartman*

\section{December 1976}

*College of Forest Resources, University of Washington, Seattle.

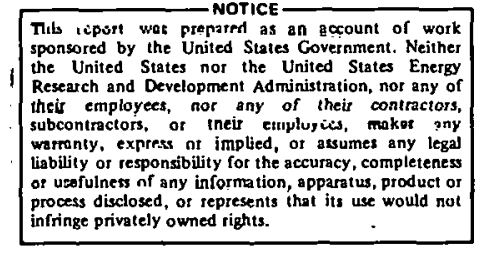

$\longrightarrow$

BROOKHAVEN NATIONAL LABORATORY UPTON, NEW YORK 11973 
NOT I C E

This report was prepared as an account of work sponsored by the United States Government. Neither the. IInited States nor thc United States Energy Research and Development Administration, nor any of their employees, nor any of their rnntrartors, sul numl arings, or their employces, makes any warranty, express or implied, or assumes any legal liability or responsibility for the accuracy, completeness or usefulness of any information, apparatus, pruduct or process disclosed, or represents that its use would not infringe privately owned rights.

Printed in the United States of America Available from

National Technical Information Service

U.S. Department of Commerce

5285 Port Royal Road

Springfield, VA 22161

Price: Printed Copy $\$ 5.00$; Microfiche $\$ 3.00$

February 1977

925 copies 


\section{FOREWORD}

This set of reference information on renewable resources and certain selected nonrenewables has been assembled for the assessment of material technologies, i.e., identification of significant new RED opportunities in the materials field, and for the analysis of renewable materials as substitutes for energy intensive nonrenewables.

In creating this assessment tool, it became abundantly clear along the way that while strong specialization exists in forest sciences and wood products on the one hand, and agricultural sciences on the other, a broader systems perspective of the renewable resources is lacking. Correspondingly, integrated statistical information on resources, material flows, and utilization including associated energy, cost and environmental aspects, is not readily available in the case of renewables. The situation is somewhat better, but still not satisfactory in the case of nonrenewables. In view of this consideration and somewhat stringent time and resource constraints, some glaring gaps in the information could not be avoided and one purpose of this report has been to identify such gaps. The most significant need is for improved information on the installation and maintenance of materials in their end use. This information is needed for the analysis of substitution and conservation options. This report should, therefore, be considered only a first approximation to what should ultimately be desirable in this sort of work. It is hoped that the experience gained in employing this tool will be used to develop this instrument further as a consistent framework for materials policy analysis.

Most of the information on renewable materials was obtained in consultation with the members of the Committee on Renewable Resources for Industrial Materials (CORRIM) which was set up under the auspices of the National Academy of Sciences to examine the role of renewable resources in meeting the nation's future. needs for materials. Informalion on nonrenewables was based on various published reports and existing compilation of original data. Our specific debts to such sources are clear throughout the report. 
THIS PAGE

\section{WAS INTENTIONALLY LEFT BLANK}




\section{Abstract}

This report presents a reference set of data related to material systems and a framework for carrying out the material technologies assessment.

While the bulk of renewables have been considered in this report, the nonrenewable materials dealt with here include structural materials only, such as steel, aluminum, cement and concrete, and bricks. The complete data set is supposed to include material flows, energy requirements, capital and labor inputs, and environmental effects for each process that a resource must go through to become a useful material for an end use. Although effort has been made to obtain as much information as possible, considerable gaps in data, apparent throughout this report, could not be avoided.

A new material technology can be evaluated by substituting that technology for appropriate elements of the reference materials system and calculating the net change in material resource, energy, capital and labor requirements, and environmental impacts. This combination of information thus serves as a means of evaluating the potential benefits to be gained by research in various material technologies. 


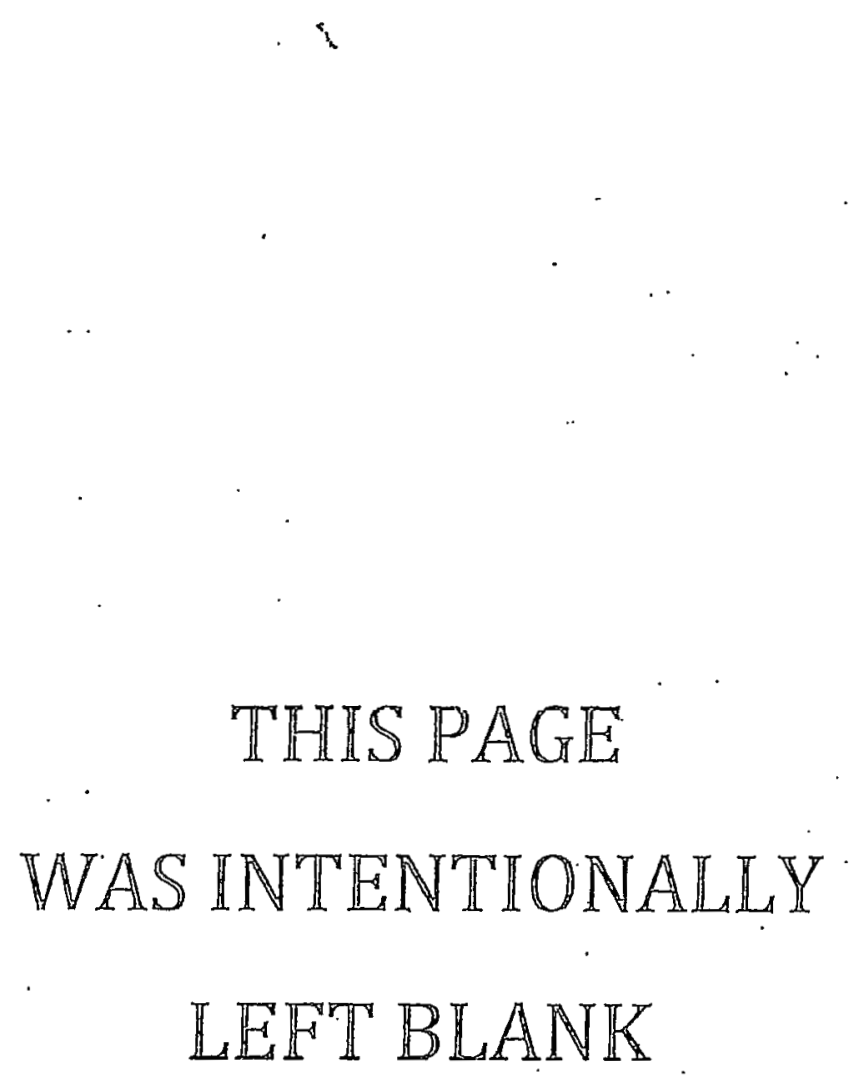


Page No.

I. INTRODUCTION AND SUMMARY........................ I

II. ECONOMIC GUIDELINES AND ASSUMPTIONS................. 5

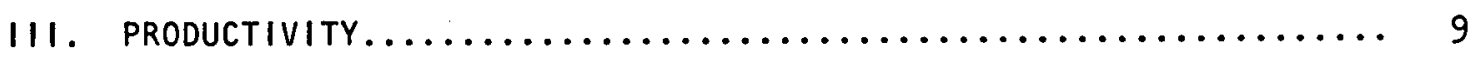

IV. MAJOR SECTORS OF THE MATERIALS SYSTEM................ 17

a. Productivity 17

b. Structural Materials 18

c. Fibers 19

d. Extractives 20

e. Lignocellulosic Materials 20

f. Fuels 21

g. Nonrenewables 24

$\forall$. MATERIALS SUBSTITUTION ANALYSIS................... 29

Case Study In Containers and Packaging Sector......... 30

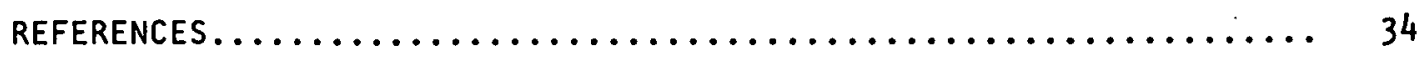


Table No. Title

Page No.

\begin{tabular}{|c|c|}
\hline $\mid 1-1$ & Population-Economic Projections \\
\hline||$-2$ & $\begin{array}{l}\text { Increase in Demand for Lumber, Plywood and } \\
\text { Board Products }\end{array}$ \\
\hline $11-3$ & $\begin{array}{l}\text { Increase in Demand for Paper and Paperboard } \\
\text { Products }\end{array}$ \\
\hline $111-1$ & $\begin{array}{l}\text { Commercial Timberland Arreage, Softwood Volume, } \\
\text { Huldwuod Volume, and the Katio of Sof twood } \\
\text { to Hardwood Volume }\end{array}$ \\
\hline$|1|-2$ & $\begin{array}{l}\text { Millions of Acres in Each Class of Forest in } \\
\text { Each Region }\end{array}$ \\
\hline $111-3$ & $\begin{array}{l}\text { Millions of Cubic Feet of Potentially Merchantable } \\
\text { Timber Produced Annually in Each Forest Region } \\
\text { and Class }\end{array}$ \\
\hline $111-4$ & $\begin{array}{l}\text { Millions of Cubic Feet of Timber Harvested from } \\
\text { Each Forest Class to Supply Specified Demands }\end{array}$ \\
\hline $111-5$ & Cost of Forest Management Practices in 1971 \\
\hline $111-6$ & $\begin{array}{l}\text { Forest Harvest Labor, Fuel, and Capital Inputs } \\
\text { for } 1972\end{array}$ \\
\hline $111-7$ & $\begin{array}{l}\text { Estimated Inputs of Labor, Fuel, and Capital } \\
\text { for National Annual Timber Harvest }\end{array}$ \\
\hline $111-8$ & $\begin{array}{l}\text { Estimated Cost of Forest Harvest Labor, Fuel, and } \\
\text { Capital Inputs for National Annual Timber Harvest }\end{array}$ \\
\hline IV-I & $\begin{array}{l}\text { Energy from Biomass Conversion -- Costs and } \\
\text { Efficiencies }\end{array}$ \\
\hline IV-2 & RMS Data for Aluminum, 1972 \\
\hline $1 V-3$ & RMS Data for Stuel, 1972 \\
\hline $1 V-4$ & RMS Data for Cement and Concrete, 1972 \\
\hline IV -5 & RMS Data for Building Brick, 1972 \\
\hline IV -6 & $\begin{array}{l}\text { Energy Requirement for Typical Containers and } \\
\text { Packaging }\end{array}$ \\
\hline
\end{tabular}


Scope of Reference Material System and Associated Data Elements

Master Reference Material System

Aggregate Reference Material System -- Mass Flows

Aggregate Reference Material System -- Energy

Requi rements

Productivity Sector I -- Material Flows

Productivity Sector $\mid 1$-- Material Flows

Productivity Sector III-- Material Flows

Productivity Sector 111 -- Labor Requirement

Structural Sector 1 -- Material Flows

Structural Sector I -- Labor Requirement

Structural Sector I -- Capital Requirement

Structural Sector $\mid 1$-- Material Flows

Structural Sector II -- Energy Requirement

Fibers (Pulp and Paper) Sector I -- Energy Requi rement

$8 \mathrm{C}$

Fibers (Pulp and Paper) Sector 1 -- Labor

* Arrangement and designation of figure numbers has been explained on p. 17. 
10A Fibers (Textiles and Apparel) Sector 111 -Material Flows

Fibers (Textiles and Apparel) Sector III -Energy Requirement

$10 \mathrm{C}$

Fibers (Textiles and Apparel) Sector III -Labor Requirement

Fibers (Textiles and Apparel) Sector IV -Material Flows

Fibers (Textiles and Apparel) Sector IV -Energy Requirement

$11 C$

Fibers (Textiles and Apparel) Sector IV -Labor Requirement

13A Fibers Sector $V$ and Lignocellulosic Sector -Material Flows

Aluminum 


\section{INTRODUCTION AND SUMMARY}

\section{Background}

A comprehensive systems approach to materials policy and analysis, the Reference Materials System (RMS), has been used in this report to assemble information on renewable resources and certain selected non renewables. The RMS methodology was initially developed at Brookhaven National Laboratory in connection with research underway at this institution, supported by the U.S. Energy Research and Development Administration (ERDA), for the assessment of the materials for the energy system. This methodology is similar to that used by Brookhaven in support of energy planning and analysis for ERDA. The background of application of RMS methodology for the assessment of the material technologies considered in this report is as follows.

At the request of the Science and Technology Cffice of the National Science Foundation, a study was carried out, under the auspices of the National Academy of Sciences, on the role of renewable resources in meeting the nation's future needs for materials. The intent was to identify the most promising areas for substituting nonrenewables by renewables, which in turn will highlight the RED programs needed to overcome the barriers to production and use of renewable resources. In other words, the objective was to make an essessment of new renewable material technologies so that the nation's renewable resources could be put to a greater use in meeting future needs for materials.

The concern of this study was with the long-term effects of the material system on the environment, on human welfare, and on the nation's natural resources. Thus, resource and environmental considerations, as well as internal costs, provide the basic criteria in evaluating new material technologies. All aspects of the material system were open for consideration, from growing and harvesting of resources through conversion technologies to the various means of using the materials.

One of the drawbacks of dealing with the renewable resources lies in the nearly complete absence of coherent statistical information on resources and technologies--those presently in use and others with potential for future applications. In view of this, a task force called Committee on Renewable Resources for Industrial Materials (CORRIM) was formed and was divided into several panels to evaluate particular technical areas in connection with renewable resources. Coordination and interaction between panels was accomplished 
through a systems panel. The final overall assessment was made by the executive committee, which was responsible for drawing conclusions from the study and for developing recommendations.

The major technological areas considered in relation to renewable resources by various panels were

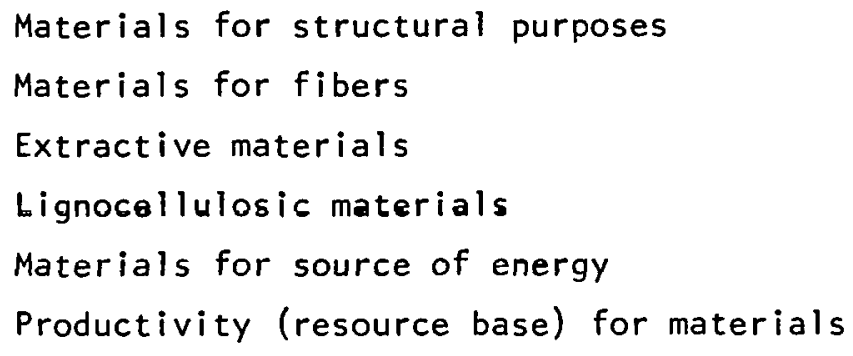

The first task before CORRIM, in order to make the required materials assessment, was to assemble coherent and integrated information on resources and technologies. In doing so, it was important that the various panels operated within the same framework. They had to use a common set of assumptions regarding the future of the materials system and the characteristics of the existing technologies. They also had to address the same basic questions, insofar as applicable, and use common economic ground rules. Apart from being just a data base format, the materials systems framework also had to be used for the purpose of technology assessment, i.e., the identification of significant new RED opportunities in the renewable materials field. In this context again, it had to be made sure that the assessments done by various panels were consistent so as to facilitate intercomparison of the benefits that would accrue from the RED under consideration. The above requirements along with the diversity and complexity of the materials system, placed a premium on integration and simplification as the two features of the materials framework. In view of these considerations, RMS was adopted by CORRIM as the data base format and material assessment tool at an early stage of its study.

RMS Methodology

The RMS facilitates the integration of diverse information on the technical, economic, and environmental aspects of the materials system in a consistent manner. It also provides a technique for the rapid assessment of a materials substitution strategy or a new technology.

The concept of an RMS is straightforward. It is a description of the major components of the material system, specifying the processes ranging from extraction of resources through their refinement, transportation, 
fabrication, and installation at the point of end use. The scope of the RMS is outlined in Figure 1. At the left hand side is a listing of resources corresponding to the materials to be considered, while the products and end uses are listed on the right hand side. The series of "activities", e.g., growing, harvesting, transportation, and fabrication, that a typical resource must go through to become a useful material for an end use are listed at the top of the figure. A completed RMS is a network representation of the flow of materials from the resource side through all the "activities" to the end uses. A path from a specific resource to a specific end use is called a trajectory. Each activity in the trajectory represents a technical process or production step that is characterized both by a flow element and by several data elements (e.g., land use, energy requirements, fertilizer and chemicals, labor, and cost).

To use the RMS in evaluating the impact of a new technology, the characteristics of the technology must first be defined in terms of resource consumption, environmental effects, energy consumption, and economics. Taking into consideration its rate of implementation, the new technology can then be inserted into the RMS to produce a Perturbed Material System (PMS). The impact of the new technology may then be evaluated by comparing the resource consumption, cost, environmental effects, etc. for the PMS with those of the RMS.

Summary

A complete RMS based on panel inputs, developed for the historical year 1972, is shown in Figure 2. The purpose of this representation is to provide an overview of the system and illustrate the interfacing between the panels' work. As an example, productivity and structural panels show logging and mill residue respectively, as outflows, while these residues are shown as inflows in the fiber trajectory. Similarly, dissolving pulp and spent liquor produced in the pulping process in the fiber trajectory are shown as inputs to lignocellulosic and extractive trajectories, respectively. This system serves to match such intertrajectory flows and thus acts as a guide to how the various trajectories, described in detail in section IV, fit together. In addition, a highly aggregated view of the Materials System is shown in tigure 2A, which displays material flows in aggregate form, as they existed in 1972. Energy requirements corresponding to these material flows, at the same level of detail, are presented in Figure 2B. These requirements may be converted to 
unit requirements on the basis of either a pound of material throughput for an activity or some unit of the final material product delivered to an end use.

In section 11 , economic guidelines useful for compiling information on future RMS's are described. Section 111 deals with productivity information that cuts across the work of all other panels. Major sectors of the renewable material system and substitutable nonrenewables have been presented in RMS format under separate chapter headings in Section IV. RMS trajectories corresponding to these sectors are shown in figures at the end of the text. Arrangement of these figures is described at the beginning of section IV. Substitution (nonrenewables by renewables) analyses have been included wherever possible, and the deficiency of the system's data is also discussed in this section. 


\section{ECONOMIC GUIDELINES AND ASSUMPTIONS}

This section outlines the economic projection guidelines developed for use by the panels. These projections provided a guide for estimating renewable resource usage in the years 1985 and 2000 under three sets of assumptions :

a. A base case representing lowest use of renewable versus nonrenewable resources under the assumption of "business-asusual"

b. A medium perturbation case representing increased potential for substituting renewable for non renewable resources

c. A high perturbation case representing the greatest foreseeable potential for substitution.

Basic population-economic projections are presented below, followed by relative price assumptions to be used for each of the three cases.

\section{Population-Economic Projections}

Basic assumptions for the year 2000 scenarios are as follows:

Population of 264 million

Modest prosperity

High environmental concern

Increasing competition for land

This population projection is consistent with the 1972 OBER's Projection, (1) Series E. Estimates of population, households, and per capita income to the year 2000 are presented in Table 11-1. These estimates were used for material flow projections for all three cases.

\begin{tabular}{|c|c|c|c|c|}
\hline \multicolumn{5}{|c|}{$\begin{array}{c}\text { TABLE } 11-1 \\
\text { POPULATION-ECONOMIC PROJECTIONS }\end{array}$} \\
\hline Year & $\begin{array}{l}\text { Population } \\
\text { (millions) }\end{array}$ & $\begin{array}{l}\text { Number of } \\
\text { Households }(2) \\
\text { (millions) }\end{array}$ & $\begin{array}{l}\text { Per capita income } \\
\text { (1972 dollars) }\end{array}$ & (1) \\
\hline 1970 & 204 & 63 & 3599 & \\
\hline 1972 & 209 & 65 & 3843 & \\
\hline 1980 & 224 & 77 & 5700 & . \\
\hline 1985 & 235 & 84 & 6500 & \\
\hline 1990 & 246 & 90 & 7400 & \\
\hline 2000 & 264 & 100 & 9800 & \\
\hline
\end{tabular}


Institutional Framework

The major feature of this assumption is that the nation will retain a private market economy through the year 2000 , i.e., the renewable resource sectors will be constituted primarily of private business and private consumption.

Relative Price Projections

Three sets of future price relationships are presented below for the three cases analyzed. Relative prices are an unknown parameter with regard to the future, and this uncertainty is handled by making the best possible estimate of the range over which relative prices may change. The worst relative price projection for renewable versus nonrenewable resources is then assumed for the base case, and the best relative price advantage is assumed for the high case. Relative prices half-way between these assumptions are used for the medium case.

Under all these price scenarios it is assumed that, by and large, there will be ample supply of renewable and nonrenewable materials at the prices projected.

1. $0 i 1$ prices:

$$
\begin{array}{ll}
\text { Base case } & \text { ca. } 1972 \text { (pre-cartel). } \\
\text { Medium case } & 1975 \text { oil prices. } \\
\text { High case } & \text { higher than } 1975 \text { oil prices; } \\
& \text { much higher than } 1975 \text { oil priccs. }
\end{array}
$$

2. Prices of structural nonrenewable resources (iron, aluminum, nonmetallic materials) vs. structural renewable resources (lumber, plywood, board products):

$$
\begin{aligned}
& \text { Base case - constant relative prices, NRR/RR } *=1.0 \\
& \text { Medium case }-N R R / R R=1.2 . \\
& \text { High case }-N R R / R R=1.4 \text {. }
\end{aligned}
$$
are shown in Table $11-2$. Taken from The Outlook for Timber in the 11.S. (p. 150), change in demand resulting from a sustained annual $1 \%$ decrease in relative prices of renewables is shown (corresponding to an $\sim 30 \%$ decrease

* NRR $=$ prices of nonrenewable resources; RR = prices of corresponding renewable resources. 
in relative prices by 2000 or halfway between the medium and high case assumptions). An approximation to the medium and high cases for structural materials can thus be made by taking two-thirds of the increase in demand shown in the table for the medium case and four-thirds of the increase shown for the high case.

\begin{tabular}{lcc} 
TABLE $11-2$ & \\
& Increase in Demand (\%) & \\
\hline No. of years after & & \\
$\frac{\text { relative price decrease }}{1}$ & $\frac{\text { Lumber, Plywood }}{0.1}$ & 0.05 \\
5 & 0.3 & 0.1 \\
10 & 0.5 & 0.2 \\
15 (extrapolated) & 0.8 & 0.3 \\
30 (extrapolated) & 1.5 & 0.5 \\
\hline
\end{tabular}

3. Prices of nonrenewable construction materials (aluminum, steel, cement, glass, etc.) vs. renewable construction materials (wood):

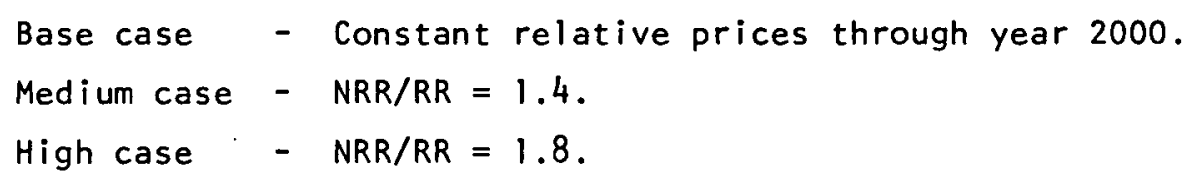

The demand elasticities used for structural resources can also be used here in projecting 1985 and 2000 material flows for the medium and high cases.

4. Prices of nonrenewable fiber materials vs. renewable wood fiber materials:

$$
\begin{aligned}
& \text { Base case - Constant relative prices. } \\
& \text { Medium case - NRR/RR }=1.3 . \\
& \text { High case - NRR/RR }=1.6 .
\end{aligned}
$$

Long-run demand elasticities for paper and paperboard products are shown in Table 11-3. Taken again from The Outlook for Timber in the U.S. (3) (p. 150), the figures show change in demand resulting from a sustained annual 1\% decrease in relative prices for renewable materials (corresponding to an $30 \%$ decrease in relative price by 2000 ). These values are used directly for medium case projections and are doubled for high case projections. 
TABLE $11-3$

\begin{tabular}{lc} 
Nu. ur years afier & $\begin{array}{c}\text { Increase In delland fur } \\
\text { relative price decrease }\end{array}$ \\
\hline 1 & $\begin{array}{c}\text { Paper and Paperboard } \\
\text { Products (\%) }\end{array}$ \\
\hline 5 & 0.05 \\
10 & 0.1 \\
15 (extrapolated) & 0.2 \\
30 (extrapolated) & 0.3 \\
\hline
\end{tabular}




\section{I1. PRODUCTIVITY}

The productivity of natural ecosystems represents a wealth of resources, with forests the major contributors to the renewable resource material flows." Forest products ultimately supplied include lumber, veneer, plywood, paper products, and chemicals. The Department of Commerce (1974) expects that, this year, lumber production will exceed $37 \times 10^{9}$ board feet valued at $\$ 8.8 \times 10^{9}$, plywood production will be $18.1 \times 10^{9}$ square feet with a value of $\$ 1.85 \times 10^{9}$, and paper production will be $69.8 \times 10^{6}$ tons (650 lb/capita) with a value of $\$ 16.4 \times 10^{9}$.

The United States consists of about 2.2 billion acres. Of these 753 million acres are forest, with $500 \mathrm{million}$ acres of commercial timberland. This acreage can be divided into four major timber regions: Northern, Southern, Rocky Mountain, and Pacific Coast.

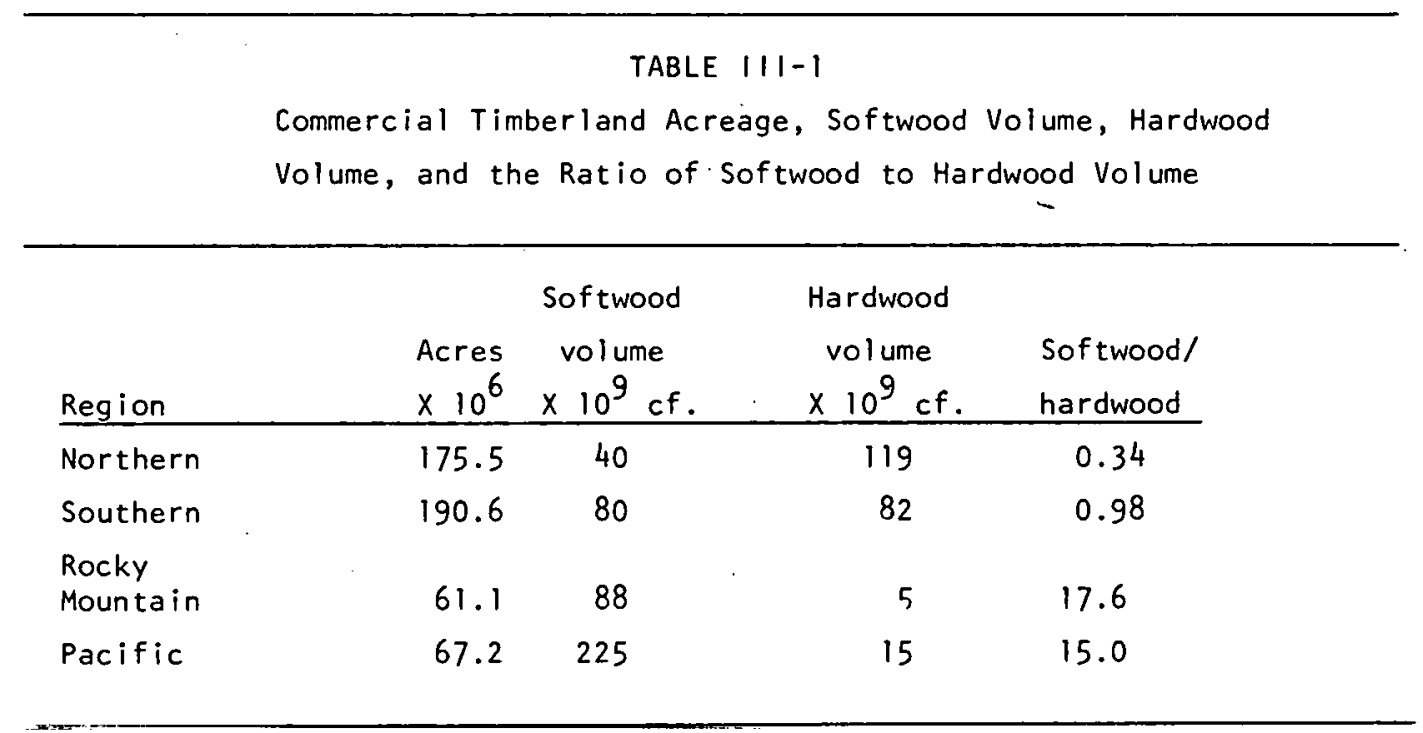

Each of these forest regions has different species compositions and volumes of timber. Table ||$|-|$ summarizes acreage, softwood volume, and the ratio of softwood to hardwood for each of the four regions.

* In the RMS for renewables, forests are the primary resource base considered. Early in the study it was estimated that about $85 \%$ of the renewable materials would come from forest resources, $10 \%$ from cotton production, and $5 \%$ from other renewables. 
Within each region there are four categories of commercial timberland: national forests, other public forests, industrial forests, and miscellaneous private forests. The national forests are administered by the U.S. Forest Service, while the other public forests are administered by local, state, and other federal agencies. Industrial forests are owned by corporations, while the miscellaneous private forests, often called the third. forest, as opposed to industrial and public forest lands, consist of forested tracts owned by individuals. Table $111-2$ summarizes the acreage by forest and region.

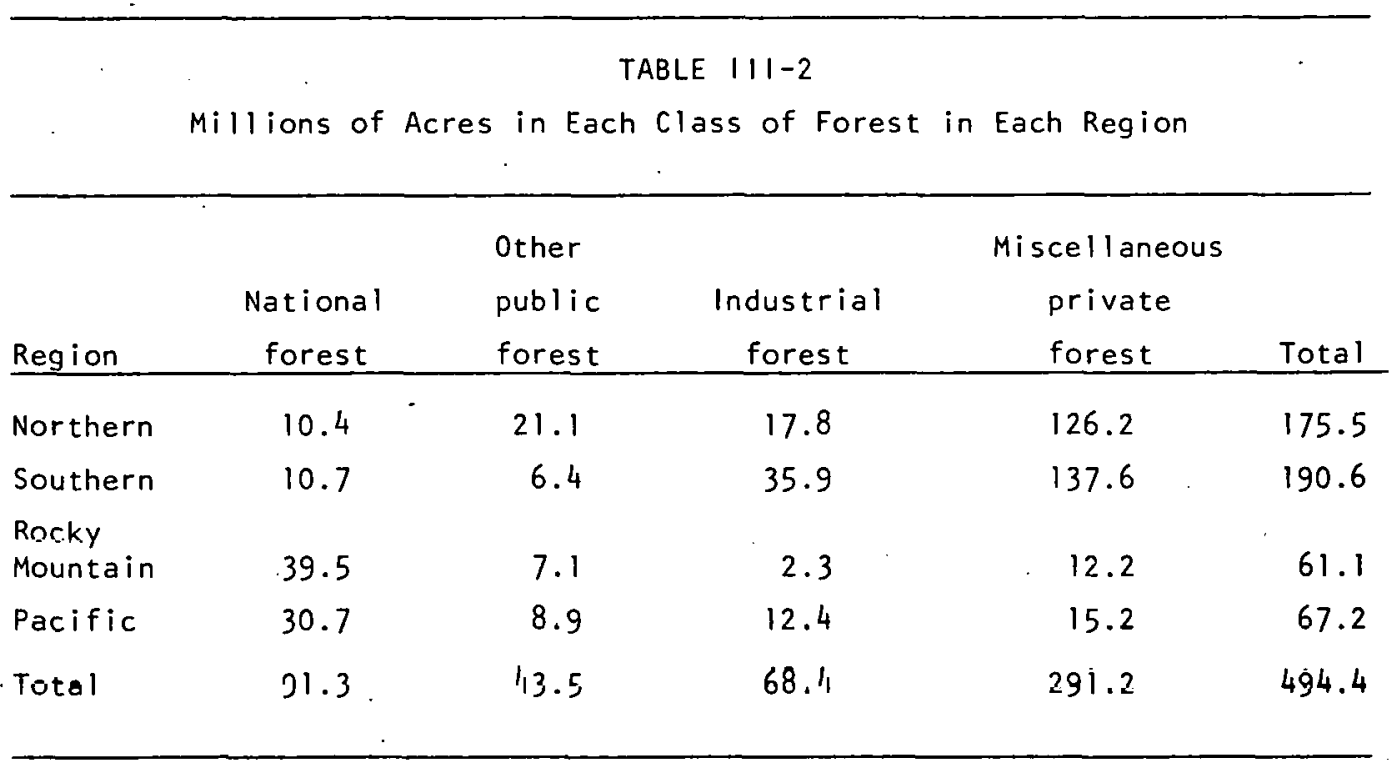

Although it is only after several years of growth that trees are harvested, it is important to know the annual rate of production of merchantable growth. Table III-3 summarizes the total volume of merchantable growth produced annually in each forest region in each class of forest. The annual rate of growth is the upper limit to the rate of removal of the forest resource. Indeed, sustained long-term harvest may be well below the annual growth rate. 
TABLE || $\mid-3$

Millions of Cubic Feet of Potentially Merchantable Timber. Produced Annually in Each Forest Region and Class

\begin{tabular}{|c|c|c|c|c|c|}
\hline Region & $\begin{array}{c}\text { National } \\
\text { forest }\end{array}$ & $\begin{array}{l}\text { Other } \\
\text { Public } \\
\text { forest }\end{array}$ & $\begin{array}{c}\text { Industrial } \\
\text { forest }\end{array}$ & $\begin{array}{c}\text { Miscellaneous } \\
\text { private } \\
\text { forest }\end{array}$ & Total \\
\hline Northern & 410 & 703 & 712 & 3,686 & 5,511 \\
\hline Southern & 594 & 299 & 1,931 & 5,846 & 8,670 \\
\hline $\begin{array}{l}\text { Rocky } \\
\text { Mountain }\end{array}$ & 892 & 168 & -- & 320 & 1,380 \\
\hline Pacific & 843 & 552 & 814 & 889 & 3,098 \\
\hline Total & 2,739 & 1,722 & 3,457 & 10,741 & 18,659 \\
\hline
\end{tabular}

Of the $18.7 \times 10^{9}$ cubic feet of merchantable timber produced in all forest classes during 1970, $\sim 14 \times 10^{9}$ cubic feet were removed. Removals supplied five major demands: pulpwood, veneer logs, saw logs, miscellaneous industrial roundwood, and fuel wood. Table $111-4$ summarizes the volume of removals from each forest class for each of the five demands.

It is extremely difficult to obtain information regarding production costs for commerclal timberlands. This is partially due to regional differences in forest productivity, differences in management activities for the four classes of forests, and in large part the unwillingness of forest products corporations to share information concerning the costs for labor, materials, fuels, fertilizer, etc. per unit of production. It is even more difficult to measure the tangible effects upon future forest productivity of present research programs (e.g., fertilization studies, genetic improvement programs, etc.). However, using the annual timber production in 1970 of 18.7 billion cubic feet, forest management costs per cubic foot of production can be estimated from information contained in The Outlook for Timber in the United States. (3)

Table 1/1-5 summarizes estimates of forest management costs. 
TABLE III -4

Millions cf Cubic Feet of Timber Harvested From Each Forest

class to Supply Specified Demands

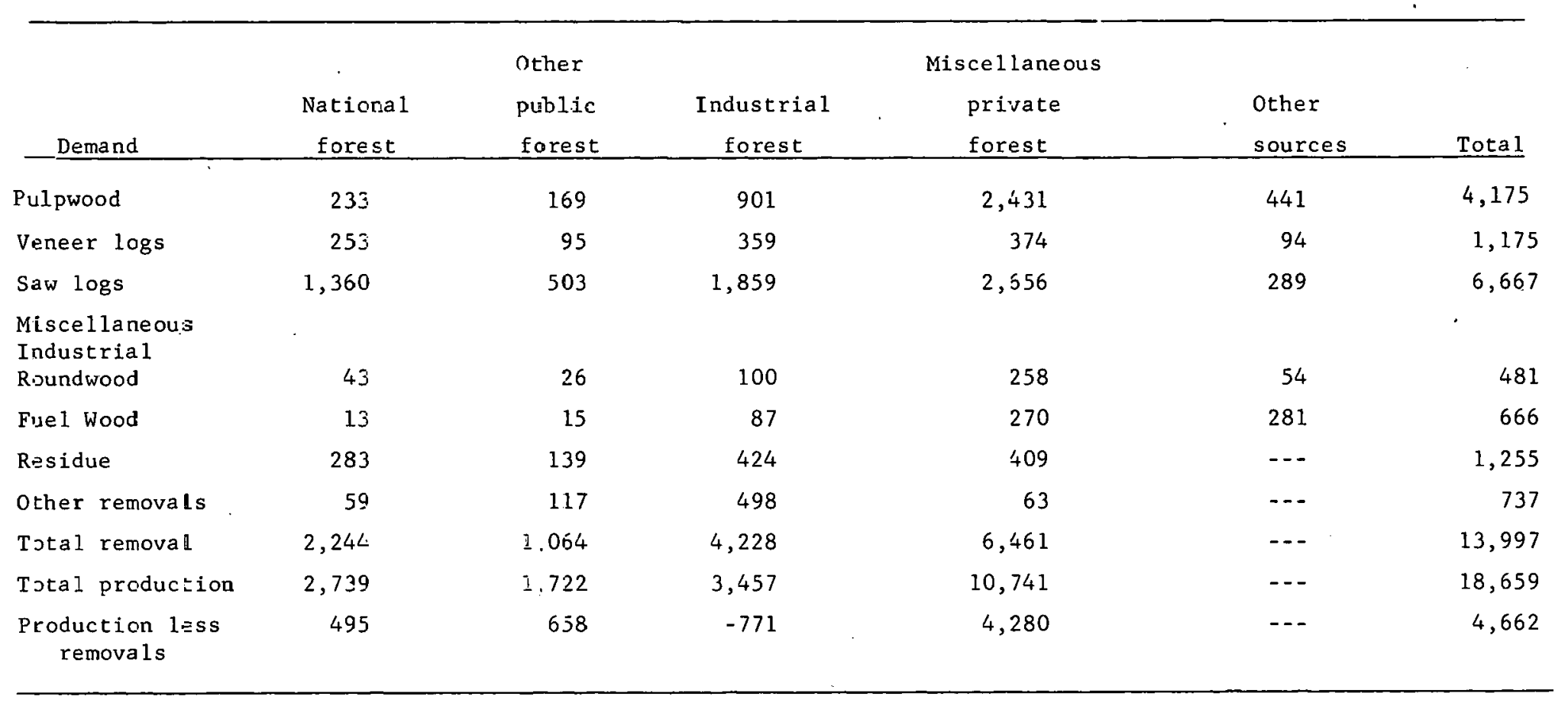




\begin{tabular}{|c|c|c|c|c|}
\hline \multicolumn{5}{|c|}{ TABLE $111-5$} \\
\hline Practice & $\begin{array}{c}\text { Total } \\
\text { cost } \\
\text { (millions } \\
\text { of dollars) }\end{array}$ & $\begin{array}{l}\text { Acreage } \\
\text { (millions } \\
\text { of acres) }\end{array}$ & $\begin{array}{l}\text { Cost per } \\
\text { acre of } \\
\text { resource } \\
\text { (dollars) }\end{array}$ & $\begin{array}{l}\text { Cost per thousand } \\
\text { cubic feet } \\
\text { of production } \\
\text { (dollars). }\end{array}$ \\
\hline Fire control & 266 & 500 & 0.53 & $\cdot 14.22$ \\
\hline Pest control & 13 & 500 & 0.03 & 0.70 \\
\hline Reforestation & 106 & 500 & 0.21 & 5.67 \\
\hline Fertilization & --- & 0.15 & -- &.- \\
\hline Research & 213 & 500 & 0.43 & 11.39 \\
\hline Total & 598 & & 1.20 & 31.98 \\
\hline
\end{tabular}

Five major activities are associated with the removal of forest production: harvest planning and layout, road construction and maintenance, stump to mill handling, equipment maintenance, and supervision. The structural materials panel has made estimates of the man-hours, energy inputs, and capital costs per unit of removal in the Pacific and Southern forest regions. Table $111-6$ summarizes labor, fuel, and capital inputs per cubic foot of timber removed in the Pacific and Southern regions. A mean value for each input is also given. Table III-7 applies the mean values to the 14 billion cubic feet of timber harvested in 1970 . Table III-8 converts the labor and fuel inputs to dollars. An average hourly wage of $\$ 4.05$ and a fuel cost of $\$ 0.30 /$ gal are assumed. The hourly wage is based on information in the 1972 Census of Manufacturers for logging camps and logging contractors. The average cost per cubic foot of timber removed is $\approx \$ 0.19$. Combining the per cubic foot production cost (Table $1 / 1-5$ ) with the removal cost (Table $111-8)$, the total cost for producing and removing one cubic foot of timber is estimated to be $\$ 0.22$. 
TABLE || $\mid-6$

Forest Harvest Labor, Fuel, and Capital Inputs for 1972

\begin{tabular}{lcll}
\hline & $\begin{array}{c}\text { Man-hours } \\
\text { per } \\
\text { cubic foot }\end{array}$ & $\begin{array}{l}\text { Gal. } \\
\text { fuel per } \\
\text { cubic foot }\end{array}$ & $\begin{array}{l}\text { Capital, } \\
\text { dollars per } \\
\text { cubic foot }\end{array}$ \\
\hline Pacific & 0.025 & 0.0548 & 0.0213 \\
Southern & 0.046 & 0.0605 & 0.0341 \\
Mian & 0.0355 & 0.05765 & 0.02635 \\
\hline
\end{tabular}

TABLE $111-7$

Estimated Inputs of Labor, Fuel, and Capital for National Annual

Timber Harvest of $14.0 \times 10^{9}$ Cubic Feet

\begin{tabular}{lccc}
\hline $\begin{array}{l}\text { Timber harvest, } \\
10^{9} \text { cubic teet }\end{array}$ & $10^{6}$ man-hours & $10^{6}$ gallons & $10^{6}$ dupilal, \\
\hline 14 & 497 & 807 & 369 \\
\hline
\end{tabular}

TABLE || $\mid-8$

Estimated Cost of Forest Harvest Labor, Fuel, and Capital Inputs

for National Annual Timber Harvest of $14.0 \times 10^{9}$ cubic feet

\begin{tabular}{ccccc}
\hline $\begin{array}{l}\text { Timber harvest, } \\
10^{9} \text { cubic feet }\end{array}$ & $\begin{array}{c}\text { Wages, } \\
10^{6} \text { dollars }\end{array}$ & $\begin{array}{c}\text { Fuel costs, } \\
10^{6} \text { dollars }\end{array}$ & $\begin{array}{l}\text { Capital, } \\
10^{6} \text { dollars }\end{array}$ & $\begin{array}{l}\text { Total } \\
10^{6} \text { dollars }\end{array}$ \\
\hline 14 & 2,012 & 242 & 369 & 2,623 \\
\hline
\end{tabular}


Energy required for the production and removal of a cubic foot of timber can also be estimated. Assuming the energy required to produce a cubic foot of timber is one-tenth the energy expended to remove a cubic foot, of timber, the total fuel input is $\approx 8000 \mathrm{Btu}$ per cubic foot. Therefore, producing and removing 14 billion cubic feet of timber annually would require about $112 \times 10^{12}$ Btu.

Major policy issues influencing forest productivity include maintenance of intensive forest management, thinning, tree improvements, fertilization and site class improvement, and withdrawal of forest acreage.

The following excerpts from the report of the productivity panel are germane to the above issues.

Any effort to estimate the total productivity of the U.S. forests must be highly tentative and based upon assumptions that greatly simplify the actual situation. However, it can be said that forest management over the past 20 years has been steadily growing more intensive, and we find that the United States, with an annual harvest of 14.0 billion cubic feet of wood in 1970, could produce 17.5 billion cubic feet in 1985 and 20.3 billion cubic feet in 2000 .

Using the following assumptions, and rounding off each category to the nearest million acres, the acreage of softwoods would be increased from 242 million to 261 million acres despite the overall loss of 20 million acres of commercial forest land, and most of this increase would be on the better sites. Assumptions:

1. The acreage of commercial land is expected to decline from 495 million to 475 million acres, the level predicted in the Outlook Study for the year 2020.

2. All Site* 1,11 , and 111 nonstocked lands, 3 million acres of Site IV lands, and 1 million of site $V$ would be reforested with sof twoods.

3. 4.9 million acres of Douglas-fir types would be raised one site class through nitrogen fertilization, and 5.8 million acres of southern pine types would also be raised one site class through drainage and phosphate fertilization.

* I through $V$ are the site quality ratings based on yields (c.f./acre/yr). These yields are: I and $11 \sim 160 ; 111 \approx 110: I V \approx 70 ; V \approx 40$. 
4. 15 million acres of pine and hardwood, and 5 million acres of upland hardwood in the South would be converted through clearcutting and planting to southern pines, with an average increase in site quality of one class due to the faster growth rate of pines on these sites.

5. Commercial forest lands would be kept well stocked with desirable species by planting and weeding as needed to produce $90 \%$ of yield table growth on Sites 1 and $11,80 \%$ on Site $111,70 \%$ on Site $1 \mathrm{~V}$, and $60 \%$ on site $V$.

The potential productivity of softwoods is $>17$ billion cubic feet per year, and that of hardwoods is >11 billion, for a total of 28 billion cubic feet. This estimated productive potential is twice the 1970 consumption of 14 billion cubic feet. Anticipated production is 67 cubic feet per acre for softwoods and 56 cubic feet per acre for hardwoods. For all species, it is 62 cubic feet per acre, compared with the present actual rate of 30 cubic feet per acre per year.

In general, normal yield table values can be increased by $25 \%$ by regular thinnings on areas clearcut and planted with softwoods, and growth would be increased by $\approx 1 \%$ per year if tree improvement programs were vigorously applied.

Applying the potential gain in growth from thinning and genetic improvement, an increase in the productive potential of $760 \mathrm{million}$ cubic feet annually in the Douglas-fir region and 1119 million from southern pine is predicted. Adding these two gains to the intensive management estimate, a total biological productive potential of 19 billion cubic feet for all softwoods and $>30$ billion cubic feet for all species is predicted.

It seems that it is entirely feasible to double the production of wood from the forests of the United States through the application of present technology while continuing to manage our forests on a sustained yield basis. 
Seven major sectors are considered here under separate headings: (a) Productivity, (b) Structural Materials, (c) Fibers, (d) Extractives, (e) Lignocellulosic Materials, ( $f$ ) Fuels, and ( $g$ ) Nonrenewables. The figures showing the RMS trajectories and subtrajectories corresponding to these sectors have been put together at the end of this report. In order to display as many data elements as available, the RMS trajectories of renewable resources used as structural materials, fibers, extractives and lignocellulosic materials were broken down into eleven subtrajectories and are shown in figures 3 through 13. The matching of these subtrajectories is facilitated by identifying these on the master RMS and by indicating for each subtrajectory, inputs from the preceding and outputs to the succeeding subtrajectories.

Four copies of each of these figures, designated $A$ through $D$, are used to display material flow, energy, labor and capital costs, respectively. The figures are arranged in serial order so that all four copies, i.e., A, B, C, and D of a figure appear before the next figure number appears. If no information on a particular data type is available for any subtrajectory, it is excluded and, therefore, the numbers do not always run consecutively. Complete trajectories and the corresponding data for other sectors, i.e., fuels, nonrenewables, and containers and packaging are confined to one figure each.

The list denoting the major sectors that the figures represent and the type of information they contain is included at the beginning of this report.

IV (a) PRODUCTIVITY

The RMS for productivity is divided into two parts, one for forest productivity (Figures 3 and 4 ) and the other for agricultural, marine, and other resources (Figure 5).

Forest Resources Productivity

Source: The information in Figures $3 A$ and $4 A$ came from The Outlook for Timber in the United States, 1970. (3) Projections for 1980 were used to interpolate 1972 estimates from the 1970 data. Acreages were taken from 1970 data. In order to display the timber inventory and growth data in a more meaningful way, many of the data from the Timber Outlook were recalculated. 
For example, the Timber Outlook does not include a breakdown of growth by class of ownership and geographical area. This was calculated with use of ratios developed from information presented in other forms.

Data Mismatches and Discrepancies: Since the 1972 growth and harvest data are interpolated by using projections made for 1980 , they are unlikely to accurately reflect the actual 1972'figures. The Census of Manufactures provides data on wood consumed in the manufacture of various wood products, and this information can be used in place of the estimated data on timber removals from the Timber Outlook, if greater accuracy is desired.

Agricultural and Other Productivity

Source: The trajectories and mass flows in Figure $5 \mathrm{~A}$ were provided by panels on fibers and extractives. In the case of agricultural and animal products, these trajectories were modified to fit the requirements of the RMS in consultation with members of the fibers panel.

Data Mismatches and Discrepancies: The mass flows of wool, provided by the USDA Economic Research Service, (4) and of cotton, provided by the National Cotton Council, (5) do not account for all of the wool and cotton used in 1972 as indicated by the 1972 Census of Manufactures ${ }^{(6)}$ for the textile industry. Acreages of available crop and range land and the amount planted in various crops could not be obtained.

IV (b) STRUCTURAL MATERIALS

The RMS for this sector is broken down into two sequential parts, shown in Figures 6 and 7 respectively.

Source: Most of the information on material flows, energy, man-hours, and capital costs displayed in the structural sector trajectories was provided by the structural materials panel. The Timber Outlook ${ }^{(3)}$ was used as the data source for materials inputs from the productivity sector to the structural sector in the year 19\%2. The mass flows for end uses were extracted from the 1972 Census of Manfactures. (6) All data on energy, capltal costs and inanhours, supplied by the structural panel, were converted to a "per pound" basis for consistency and displayed as such on the trajectories. 
Data Deficiencies: Data in the "Additional Fabrication" (or Erection) column were not available at the level of detail desired so aggregation had to be done in this part of the trajectory. Although materials flow data for 1972 is nearly complete, several other data gaps could not be avoided.

IV (c) FIBERS

The RMS for fibers is divided into two parts, one for pulp and paper (Figures 8 and 9), and the other for textiles (Figure 10 and 11 ).

\section{Pulp and Paper}

Source: The wood fibers inputs in Figure $8 \mathrm{~A}$ are from The Outlook for Timber in the United States. (3) Cubic feet volume was converted to oven-dry pounds using average weighted densities ${ }^{(7)}$ for roundwood pulpwood of 29.5 OD $1 \mathrm{bs} / \mathrm{ft}^{3}$ and for $\mathrm{mill}$ residue chips of $28.100 \mathrm{lbs} / \mathrm{ft}^{3}$. Import and export figures came from the 1972 FAO Yearbook of Forest Products (8) data converted to ovendry pounds. The remaining mass flows in Figures $8 \mathrm{~A}$ and $9 \mathrm{~A}$ were taken from the RMS prepared by the fibers panel. This data was in air-dry tons and was converted using factors of 1800 OD lbs/air-dry ton for pulp, and 1900 OD lbs/airdry ton for paper. (7) The fibers panel had obtained most of the data from the American Paper Institute, (9) and some from the 1972 Census of Manufactures. Energy and man-hours data (Figures $8 B$ and $C$ ) were taken from the 1972 Census of Manufactures ${ }^{(6)}$ and divided by the respective mass flows. Data Mismatches and Deficiencies: The pulpwood inputs were projected from 1970 data as noted in the discussion on productivity. The Census of Manufactures (6) gives pulpwood consumption figures by mill type for 1972 and this data should provide a better match with the remaining pulp and paper flows. The detailed breakdown of enverting operations and end use categories was not used in preparing this RMS because of unavailability of disaggregated data.

Textiles and Apparel

Source: The inputs in Figure $10 \mathrm{~A}$ comprise of fiber materials from productivity (Figure 5A) and lignocellulosic (Figure 13A) sectors. The remaining flows were calculated from the 1972 Census of Manufactures. (6) Up to the fabrication step, all flows could be kept in pounds; however, data on products such as carpets are available in traditional units of square yards, and no satisfactory conversion factor was available. Therefore, the traditional units are used in Figure llA. Energy and man-hour data (Figures $10 B$ and $10 C, 11 B$ and $11 C$ ) were extracted from the Census of Manufactures. 
Data Mismatches and Deficiencies: The mass flow inputs in Figure 10A do not match those in the transportation column, which were taken from the "materials consumed" tables in the Census of Manufactures. "6) No satisfactory explanation was found for the inconsistency in the two sets of data, and therefore this mismatch remained unresolved. Some of the links do not have mass flows in the "additional fabrication" and "end use" columns of the trajectory because several diverse products combine along such links.

\section{IV (d) EXTRACTIVES}

Source: Most of the quantities on mass flow, energy, man-hours and capital cost displayed in the trajectories on extractives were provided by the extractives panel. The RMS for this sector is shown in Figure 12.

Data Deficiencies: Several mass flow data are missing and the information on energy, labor, and capital requirements is extremely sparse. In addition, projections for the years 1985 and 2000 are not available.

\section{IV (e) LIGNOCELLULOSIC MATERIALS}

The RMS for lignocellulosic materials sector is shown in Figure 13. The major material inputs to this trajectory are dissolving pulp and pulping coproducts and by-products from the fibers' sector (Figure 8). Agricultural residues (oat hulls and corncobs) from the productivity sector (Figure 5) constitute other input materials. The outputs of this sector are chemicals, and fibers that are used as inputs to weaving mills for production of fabrics (Figure 10 and 11 ).

Source: The trajectory and the data in Figure 13 were developed in conjunction with the lignocellulosic panel.

Data Mismatches and Deficiencies: Several contradictions were noted with respect to the total amount of dissolving pulp and chemical cellulose produced in 1972, as reported by the 1972 Census of Manufactures,

(6) the Daily News Record of June 16, 1975, the Stanford Research Institute's Chemical Economics Handbook, (10) and the American Paper institute. (9) In this report, the Daily News Record data were used at the suggestion of the lignocellulosic panel. Data on energy consumption and man-hours are available on an aggregate basis in the 1972 Census of Manufactures, (6) but transformation to conform to the activities' classification shown on the RMS trajectory was not possible. 
IV (f) FUELS $(11-16)$

Biomass is a renewable resource that has significant potential as a source of energy. Several potential sources of biomass are available. Formal plantation entailing the cultivation of selected, high-yield plant species, e.g., red alder, for the sole purpose of biomass production constitutes one source. Reported growth for red alder stands in the Pacific Coast area ranges from 4 to 33 tons/acre-year. Marine plantations are another source of biomass that require further exploration. Other biomass sources include natural land vegetation produced under natural conditions and agricultural/forest wastes and residues. Environmental implications of harvesting wild vegetation warrant close inspection of exploitation of this resource. Agricultural/ forest wastes and residues constitute an impressive tonnage of biomass when viewed on the national scale. According to a Bureau of Mines (13) study, $650 \mathrm{million}$ dry tons of such residues are generated in the United States each year. Still another source of biomass is provided by municipal waste. One estimate ${ }^{(14)}$ of collected or collectible municipal waste biomass in the U.S. is $170 \mathrm{million}$ tons/year.

The following conversion schemes provide the most feasible alternatives to obtaining fuels from biomass:

- Electric power generation by direct combustion or low Btu gas/combined cycle

- Production of methanol

- Production of substitute natural gas (SNG)

In Figure 14 the RMS trajectory incorporating the above conversion technologies is shown. For the purpose of comparison, the trajectory for coal conversion to the same end-use fuel forms is included. Numbers in parentheses below the activity links are the process efficiencies, and those just above the product names are their heating values. No mass flows are shown, since commercial biomass-to-energy conversion did not exist in 1972. Table IV-1 includes various conversion costs (capital plus $0 \& M$ ) in aggregated form.

Assuming the price of coal to be $\$ 10 /$ ton or $50 \xi / 10^{6} \mathrm{Btu}$, the cost of electricity by direct combustion of coal is $\$ 3.49 / 10^{6}$ Btu, obtained by summing the conversion and fuel cost. For biomass to be competitive with coal for power generation, its price should be no more than $57 c / 10^{6}$ Btu which is the difference between coal-to-electric total cost and biomass-to-electric conversion cost (from Table IV-I). This is equivalent to $\$ 9.12$ per ton of agricultural/forest waste assuming biomass to have an average heating value 
Table IV -1

Energy from Biomass Conversion--Costs and Efficiencies

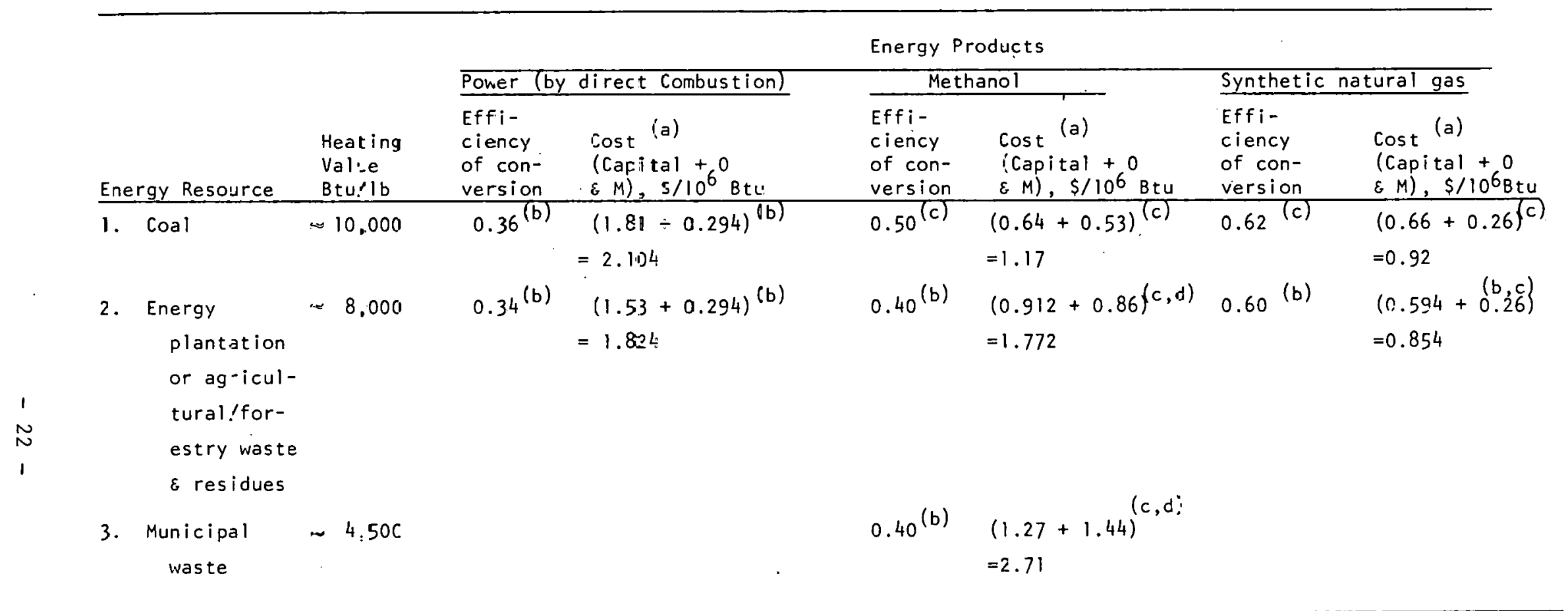

(a) Costs are tased on an approximate plant size of $250 \times 10^{9} \mathrm{Btu} /$ day.

(b) From Ref. 15

(c) From Ref. 16

(d) From Ref. 14

Notes: 1. Total collezted or collectible municipal waste is $170 \times 10^{6}$ dry tons annually.

2. Logging anc mill residues amount to 23.3 \& $24.3 \mathrm{million}$ tons, respectively, per year.

3. Total agricultural/forestry wastes and residues equal $650 \mathrm{million}$ dry tons each year. 
of $8000 \mathrm{Btu} / \mathrm{lb}$. Similarly, maximum competitive prices of biomass can be computed for other conversions, as tabulated below.

\section{Maximum Competitive Price}

Agric./forest

Assumed coal

price (\$/ton)

End-use fuel form

1. Electricity (by direct combustion)

2. Methanol

3. SNG

\section{residue \& waste}

$(\$ /$ ton)

10
10
10

9.12

2.56

8.41
Municipal

waste

$(\$ /$ ton $)$

From the above results it is clear that direct combustion of biomass for generation of power is the most attractive alternative for biomass to be used as a source of energy. Conversion to methanol turns out to be least attractive because of the high capital expenditures involved. The cost disadvantage for municipal waste is not surprising, given its low heating value. Municipal waste would not be attractive as a fuel unless new environmental regulations required much greater expenditures for its disposal than is now the case in incineration or in sanitary landfills.

For a biomass conversion scheme to be economically feasible, the "competitive price" of biomass given above would have to be as high as Its prevailing market value, which, of course, depends on the other uses of biomass. Alternative uses of biomass are numerous -- crop residues are used for livestock feed, field mulch and improvement of soil tilth; and some forest residues are used for soil amendment and manufacture of wood products. With the continued depletion of fossil fuels, it seems likely that future energy prices will put biomass in a more favorable position as an energy feedstock. The present lack of commercial methods for removing sulfur from coal or sulfur oxide compounds from the combustion products makes the low sulfur content of biomass even more important. On the cost front, one of the most significant factors is transportation. This factor can lead to highly attractive localized situations for biomass conversion to energy when supply and demand centers are located in close proximity. 
IV. (g) NONRENEWABLES

The RMS trajectories for aluminum, steel, and cement and concrete; shown in Figures 15, 16, \& 17 respectively, display the mass flow and energy data. Capital and labor costs, available only on a more aggregate basis, have been tabulated along with the energy data in Table IV-2 through IV-5.

Source: Most of the energy data were obtained from the Conference Board's book, Energy Consumption in Manufacturing, (17) while the Census of Manufactures $^{(6)}$ was used for capital and labor costs for processing and manufacturing. Energy data associated with mining, refining, etc. was taken from Energy Expenditures Associated with the Production and Recycling of Metals. (18) Capital and labor data for mining and related activities were obtained from the 1972 Census of Minerals (19) and the Minerals Yearbook. (20) 
Table IV - 2

RMS Data for Aluminum, 1972

\begin{tabular}{|c|c|c|c|c|c|c|c|}
\hline \multirow[t]{2}{*}{ Activity } & \multicolumn{2}{|c|}{ Energy Input } & \multicolumn{3}{|c|}{ Labor } & \multicolumn{2}{|c|}{ Capital } \\
\hline & $\begin{array}{r}\text { Nonelectric } \\
(B t u / 1 b)\end{array}$ & $\begin{array}{l}\text { Electric } \\
(\text { Btu/1b) }\end{array}$ & $\begin{array}{l}\text { Scientific } \\
(\text { Man-hr/lb) }\end{array}$ & $\begin{array}{r}\text { Production } \\
\text { (man-hr } / 10^{3}\end{array}$ & 1b) & $\begin{array}{l}\left(\$ / 10^{3}\right. \\
1 \mathrm{~b} / \mathrm{yr})\end{array}$ & $\begin{array}{r}\left(\$ / 10^{3}\right. \\
1 b) \\
\end{array}$ \\
\hline $\begin{array}{l}\text { Production / } \\
\text { growing } \\
\text { (mining) }\end{array}$ & 0 & 305 & N.A. & & & & \\
\hline $\begin{array}{l}\text { Harvesting/ } \\
\text { extraction } \\
\text { (ore treat- } \\
\text { ment) }\end{array}$ & 7,643 & 1,843 & $\mathrm{~N} . \mathrm{A}$. & & & & \\
\hline Processing & 606 & 67,059 & N.A. & & & & \\
\hline $\begin{array}{l}\text { Transporta- } \\
\text { tion } \\
\text { (aggregate) }\end{array}$ & 801 & 0 & $N_{0} A$. & & & $?$ & \\
\hline Fabrication & $>10,675$ & 9,466 & N.A. & & & & \\
\hline $\begin{array}{l}\text { Additional } \\
\quad \text { fabrication }\end{array}$ & & & N.A. & & & & \\
\hline Total & 19,725 & $82 ; 673$ & & 26.9 & & 268.9 & 40.3 \\
\hline
\end{tabular}

Notes :

a. Current stock (reserve): $4.2 \times 10^{10} 1 \mathrm{~b}$ (metal content in high-grade ore)

b. Usage/yr: $9.6 \times 10^{9} 1 \mathrm{~b}$

c. N.A. stands fur "not available".

d. Mass units in the above data elements refer to pounds of aluminum ingots. 
Table IV - 3

RMS data for Steel, 1972

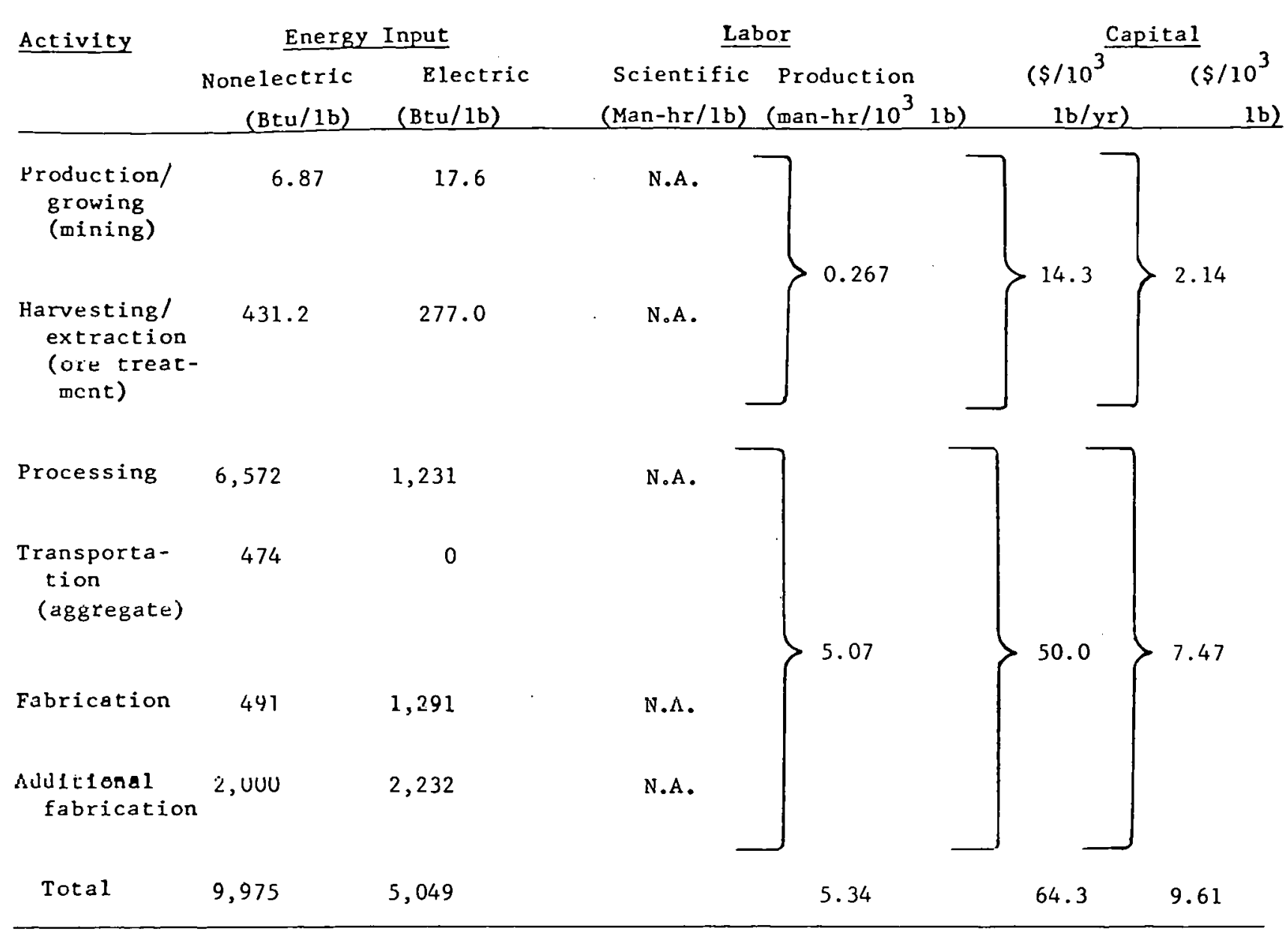

Notes:

a. Current stock (reserve): $6.4 \times 10^{13}$ lb (metal content of ore)

u. Usage/yr: $1.75 \times 10^{11} 1 \mathrm{~b}$ (metal content of ore)

c. N.A. slands for "not available"

d. Mass units in the above data elements refer to pounds of raw (ingot) steel. 
Table IV - 4

RMS Data for Cement and Concrete, 1972

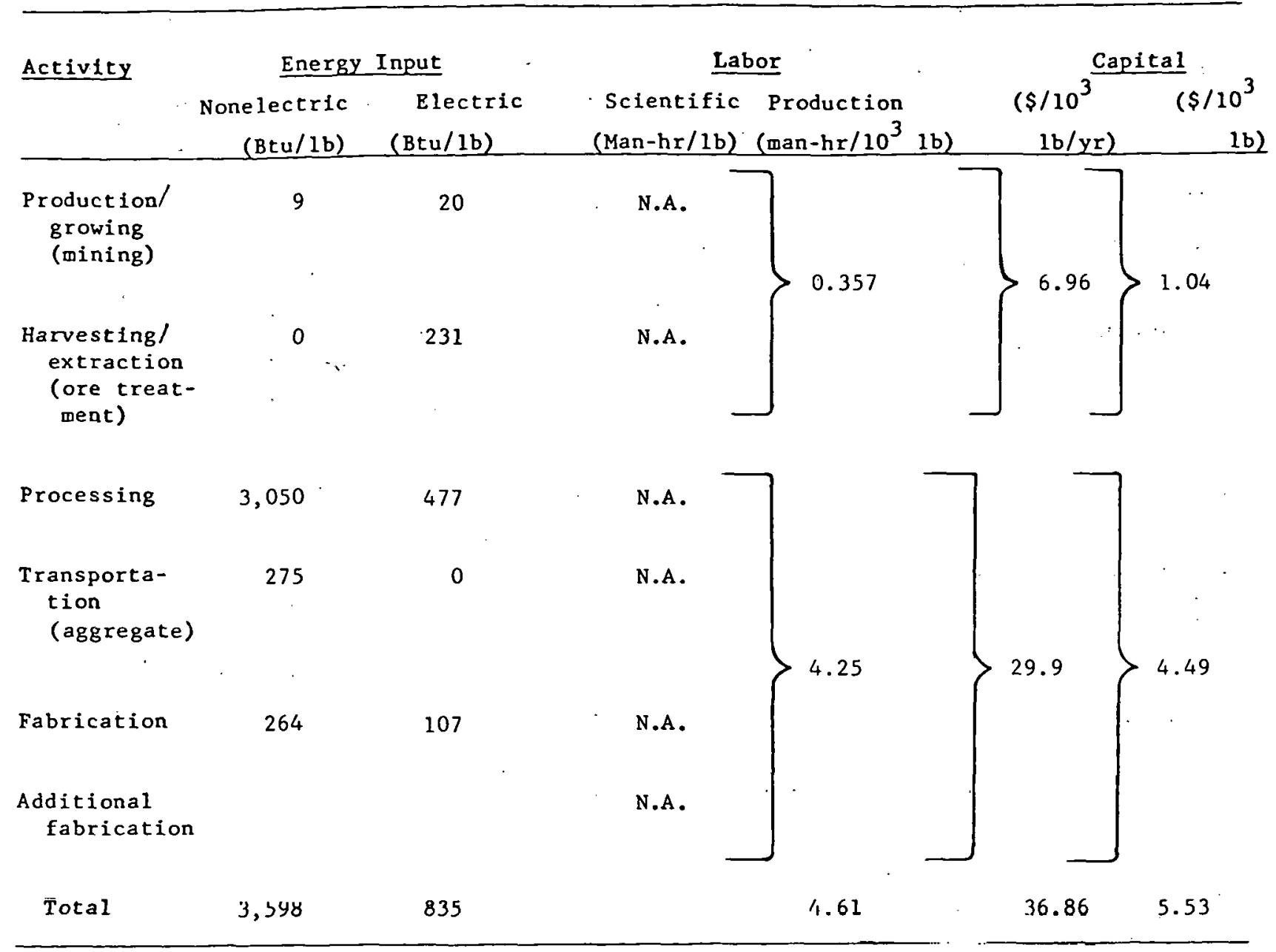

Notes:

a. Current stock (reserve): Unknown. 15-20\% of the surface of the U.S. is estimated to be underlaid with limestone.

b. Usage/yr: $1.29 \times 10^{11}$ lb limestone; $3.23 \times 10^{10} \mathrm{lb}$ clay.

c. N.A. sțands for "not available"

d. Mass units in the ahnve data elements refer to pounds of cement. 
Table IV - 5

RMS Data for Building Brick, 1972

\begin{tabular}{|c|c|c|c|c|c|c|c|}
\hline \multirow{2}{*}{ Activity } & \multicolumn{2}{|c|}{ Energy Input } & \multicolumn{2}{|c|}{ Labor } & & \multicolumn{2}{|c|}{ Capital } \\
\hline & $\begin{array}{r}\text { Nonelectric } \\
(B t u / 1 b)\end{array}$ & $\begin{array}{l}\text { Electric } \\
(\mathrm{Btu} / \mathrm{lb})\end{array}$ & $\begin{array}{l}\text { Scientific } \\
(\text { Man-hr/lb) }\end{array}$ & $\begin{array}{r}\text { Production } \\
\left(\operatorname{man}-\mathrm{hr} / 10^{3}\right.\end{array}$ & 1b) & $\begin{array}{r}\left(\$ / 10^{3}\right. \\
1 \mathrm{~b} / \mathrm{yr}) \\
\end{array}$ & $\begin{array}{r}\left(\$ / 10^{3}\right. \\
1 \mathrm{~b}) \\
\end{array}$ \\
\hline $\begin{array}{l}\text { Productiun/ } \\
\text { growing } \\
\text { (mining) }\end{array}$ & 9 & 20 & N.A. & N.A. & & & \\
\hline $\begin{array}{l}\text { Harvesting/ } \\
\text { extraction } \\
\text { (ore treat- } \\
\text { ment) }\end{array}$ & 0 & 254 & N.A. & N.A. & & & \\
\hline Processing & 3,580 & 0 & N.A. & & & & \\
\hline $\begin{array}{l}\text { Transporta- } \\
\text { tion } \\
\text { (aggregate) }\end{array}$ & 146 & & N.A. & 1.46 & & 29.9 & $4.1 ?$ \\
\hline Fabrication & 0 & 0 & N.A. & & & & \\
\hline $\begin{array}{l}\text { Additional } \\
\text { fabrication }\end{array}$ & 226 & 36.8 & M.A. & & & & \\
\hline Total & 3,961 & 331 & & 1.46 & & 30.83 & 4.63 \\
\hline
\end{tabular}

Notes:

a. Current stock (reserve): Clay is plentiful on a nationwide basis.

b. Usage/yr: $3.31 \times 10^{10} \mathrm{lb}$ for 1967 .

c. N.A. slmtuls for "not available"

d. Mass units in the abnve data elements refer to pounds of brick produced. 


\section{MATERIALS SUBSTITUTION ANALYSIS}

The Reference Materials System is used for the analysis of materials use and substitution by the technique of perturbation analysis. Depending on the details of the analysis to be performed, RMS may be used at the level of aggregation presented in a previous section or at the more detailed level. Regardless of the level of detail used in the analysis, however, the results may be presented for overview or policy purposes in RMS format used in the previous section of this report.

The technique of perturbation analysis involves the following basic steps:

1. Analysis of the specific end use involved in a use or substitution problem.

2. Definition of any new processes to be used in the affected trajectory from the resources to the specific end use (definition of losses; energy, labor, and capital requirements; and environmental effects).

3. Revision of flows through the affected trajectories in RMS to reflect the revised use or substitution of materials and/or new processes.

4. Accumulation and tabulation of resources, energy, labor, capital, and environmental consequences of the use or substitution.

In analyzing the specific nature of the substitution, it is necessary to address the specific application. The mass ratio of substitution (e.g., pounds of paper that would replace a pound of plactic) depends on the specific application and the nature of the material. One would thus have to focus, for example, on paper bags as a substitute for polyethylene bags. The determination of these substitution ratios must be done exogenousily to RMS and the results reflected in the revised or perturbed RMS. In rertain instances, material preferences and substitution may be constrained or influenced by such factors as esthetics and codes or standards. The parameters of the technical characterIstics of new processes must also be estimated exogenously to RMS by people with a processing background. The intent of RMS format is to capture those characteristics of the technology that are important to materials policy. Such technical detail, or reality, is often overlooked in policy formulation because it is not available in a consistent and comprehensive format. 
Following these steps, the perturbation of the appropriate trajectories and the accumulation of information on detailed consequences is straightforward using RMS. In the case of an analysis of the substitution of paper bags for polyethylene bags, for example, the flows through the wood to paper trajectory would increase by the appropriate amount, while the flow of crude oil and natural gas through the petrochemical trajectory would be decreased. The full materials system implications may then be traced all the way back to the forest and the source of the oil, imported or domestic. The results of the analysis may then be used as a basis of support or revisinn of the original use or substitution measure.

When used in this fashion, RMS can be a useful technique for the analysis of materials policy: It must be recognized that the technique focuses on the physical struccure of the system and its requirements. Thus, al though substitution analysis may be performed in a rather direct manner; in cases of more general policy analysis, the effects of a policy action on the supply or demand for materials used, and on the physical structure of the system, must be developed or estimated prior to use of RMS.

\section{Case Study In Containers and Packaging Sector}

The Reference Materials System provides a basis for analysis of the consequences of materials substitution. The RMS data on mass flow, energy, labor, and capital requirements allows these factors to be addressed in some detail. In order lu demonstrate the application of RMS to materials substitution analysis, two illustrative case studies have been developed. These deal with the area of containers and packaging where paper products compete with plastics.

These case studies illustrate the use of RMS to analyze energy requirements of alternative materials used in the same end use. It should be remembered that, before economic analysis can be performed, similar RMS analyses should be performed on labor requirements, capital cost requirements, and other aspects important to the situation. These case studies are therefore illustrotions of the use of RMS and insights gained, rather than a complete economic analysis among the alternatives presented. 
Because numerous possibilities of material substitution exist in the field of containers and packaging, this particular area was chosen to be the subject of our case study. Packaging and containers are.also important because they consume significantly larger amounts of energy than other consumer services such as transportation, storage and marketing, etc.

Packaging is used for three major classes of goods, durables, nondurables, and foodstuffs. The overwhelming fraction of durable goods are packaged in corrugated cardboard. Corrugated cardboard is also most commonly used as a packing material in case of durables. Nondurables consist of clothing, textiles, and chemicals and require a variety of packaging characteristics. Foodstuffs, the third major area for packaging, represent about $15 \%$ of the production activity of the U.S. economy and account for $60 \%$ of the total shipment value of the entire range of goods that are packaged. This sector involves the widest variety and largest amount of packaging materials, apart from corrugated cardboard (produced from renewable resources). In the following discussion, specific examples are given for which the technology for substitution already exists, i.e., packaging cases in which both nonrenewables and renewables can be interchangeably used to meet certain packaging requirements. Such examples are:

Sanitary food containers, used for milk, butter, margarine, frozen foods, ice cream, shortening, etc.

Trays for packaging meats, eggs, and produce.

Flexible containers, e.g., bags and sacks.

Although labor requirements and capital costs are also important considerations in the comparison of alternative materials, attention is focused exclusively on energy implications in this case study of materials for containers and. packaging.

In connection with sanitary food containers, shown in Figure 18. These correspond to the special case of half-gallon containers made of plastic and of paper. Mass flows and energy values shown in the figure under each activity link refer to requirements for manufacture of one container of each type. Energy data (21) are in terms of the "gross" 
value of energy requirement. Summing all the energy components along the two trajectories, one can see that a plastic bottle weighing $0.12 \mathrm{lb}$ needs about 8495 Btu's, whereas an equivalent paper carton weighing $0.14 \mathrm{lb}$ needs 6053 Btu's. Also, the plastic bottle requires $0.038 \mathrm{lb}$ and $0.107 \mathrm{lb}$ of natural gas and crude oil, respectively, as chemical feedstock, while an equivalent paper carton needs 0.28 ib of groundwood. Adding the energy content of raw materials, the total energy inputs to a plastic bottle and an equivalent paper carton work out to 11,310 and 7453 Btu's respectively. In Figure 19 two trajectories for the manufacture of size 6 meat trays from styrofoam and from molded wood pulp are shown. The energy requirements in the two cases add up to about the same value, 875 Btu's each. Here again, taking into account that $0.0047 \mathrm{lb}$ of natural gas and $0.013 \mathrm{lb}$ of crude oil are needed as chemical feedstocks in the case of the polystyrene tray and $0.064 \mathrm{lb}$ of groundwood is needed as raw material for one pulp tray, the total energy values increase to 1219 and 1195 Btu's respectively. In the case of flexible containers, polyethylene is used for plastic bags and Kraft paper for paper bags. The energy cost of Kraft paper (21) is $\approx 20,500$ $\mathrm{Btu} / \mathrm{Ib}$, and that of polyethylene, $(22) \approx 68,250 \mathrm{Btu} / \mathrm{lb} .$, or 3.3 times as much. But, because medium-weight polyethylene bags weigh only half as much as an equivalent paper bag, the ratio of energy consumption of plastic and paper bags is $\approx 1.65: 1$.

The above comparison is not entirely fair to plastics if there is the possibility of reusing the plastic containers. As an example, to make and fill a half-gallon plastic milk container a single time requires about 8500 Btu of energy. If it were reused, and the washing and filling costs remained the same with each use $(\approx 3070 \mathrm{Btu})$, then the cost would drop to $5785 \mathrm{Btu}$ with one reuse, to 4880 with two reuses, and to 4427 with three reuses. Similarly, although a single use of plastic bags requires more energy than paper bags, the two become comparable if more durable polyethylene bags are reused once. Despite significant energy savings as a result of reuse, it is not certain that the creation of commerclal facilities to make such reuse possible is economical. These results are summarized in Table IV-6. 
Table IV-6

Energy Requirement for Typical Containers and Packaging

\begin{tabular}{|c|c|c|c|c|c|c|c|c|}
\hline \multirow[b]{2}{*}{$\begin{array}{l}\text { Container/packag- } \\
\text { ing (product) } \\
\text { type }\end{array}$} & \multirow[b]{2}{*}{$\begin{array}{r}\text { Unit } \\
\text { weight } \\
\text { (1b) } \\
\end{array}$} & \multicolumn{3}{|c|}{$\begin{array}{l}\text { Raw material requirements } \\
\text { Per unit product }\end{array}$} & \multicolumn{2}{|c|}{ Energy of manufacture } & \multirow{2}{*}{$\begin{array}{l}\text { Energy con- } \\
\text { tent of raw } \\
\text { materials } \\
\text { per unit } \\
\text { product } \\
\text { (Btu) }\end{array}$} & \multirow{2}{*}{$\begin{array}{c}\text { Total Energy } \\
\text { per unit } \\
\text { product } \\
(\text { Btu })\end{array}$} \\
\hline & & $\begin{array}{c}\text { Natural } \\
\text { gas } \\
(1 \mathrm{~b}) \\
\end{array}$ & $\begin{array}{l}\text { Crude } \\
\text { oil } \\
\text { (1b) } \\
\end{array}$ & $\begin{array}{l}\text { Wood } \\
(1 \mathrm{~b})\end{array}$ & $\begin{array}{c}\text { per unit } \\
\text { product } \\
(B t u)\end{array}$ & $\begin{array}{c}\text { (Btu/1b of } \\
\text { product) }\end{array}$ & & \\
\hline $\begin{array}{l}\text { 1. Half-gallon } \\
\text { Milk Container }\end{array}$ & & & & . & & & & \\
\hline $\begin{array}{l}\text { Polyethylene } \\
\text { Plastic }\end{array}$ & 0.12 & 0.038 & 0.107 & $\cdots$ & $\left\{\begin{array}{l}8,495 \\
5,445 *\end{array}\right.$ & $\left\{\begin{array}{l}70,790 \\
45,370 *\end{array}\right.$ & 2,814 & 11,310 \\
\hline Paper & 0.14 & $\cdots$ & $\cdots$ & 0.28 & $\left\{\begin{array}{l}6,053 \\
2,840 *\end{array}\right.$ & $\left\{\begin{array}{l}43,230 \\
20,280 *\end{array}\right.$ & 1,400 & 7,453 \\
\hline $\begin{array}{l}\text { 2. Size } 6 \text { Meat } \\
\text { Tray } \\
\end{array}$ & & & & & & & & \\
\hline $\begin{array}{c}\text { Polystyrene } \\
\text { plastic }\end{array}$ & 0.0148 & 0.0047 & 0.013 & $-\cdots$ & 875 & 59,120 & 344 & 1,219 \\
\hline Wood pulp & 0.045 & $\cdots$ & $\cdots$ & 0.064 & 875 & 19,440 & 320 & 1,195 \\
\hline $\begin{array}{l}\text { 3. Flexible } \\
\text { Container (bag } \\
\text { or sack) } \\
\end{array}$ & & $\cdot$ & & & . & & & \\
\hline $\begin{array}{l}\text { Polyethylene } \\
\text { plastic }\end{array}$ & 0.04 & 0.013 & 0.036 & $\cdots-$ & 2,730 & 68,250 & 951 & 3,681 \\
\hline Kraft paper & 0.08 & $\ldots-$ & $\cdots$ & 0.16 & 1,640 & 20,500 & 800 & 2,440 \\
\hline
\end{tabular}

*These values exclude the energy required for filling the containers. 


\section{REFERENCES}

1. OBER's Projections, U.S. Water Resources Council: Series E, Population, 1972.

2. U.S. Department of Commerce/Bureau of the Census: Population Estimates and Projections (Current Population Reports), 1975.

3. U.S. Department of Agriculture, Forest Service: The Outlook for Timber in the United States, July 1974.

4. Glade, E., and Evans, S., USDA Economic Research Service: Private communication, 1975.

5. Bowling, A., National Cotton Council: Private communication, 1975.

6. U.S. Department of Commerce: 1972 Census of Manufactures, April 1975.

7. Forest Products Laboratory, Forest Science, U.S. Department of Agrieulture: Wood Handbook, August 1974.

8. Food and Agriculture Organization of the United Nations: 1972 Yearbook of Forest Products, 1974.

9. American Paper Institute: Private communication, 1975.

10. Stanford Research Institute: Chemical Economics Handbook.

11. University of Washington, Seattle: Discussion Meeting on Energy from Forest Residues, June 24 and 25, 1975.

12. Corlett, R. F., Mathematical Sciences Northwest, Inc.: Conversion of Seattle's Solid Waste to Methanol or Ammonia, The Trend in Engineering, April 1975.

13. Jaffe, H., et al: Methanol from Coal for the Automotive Market, Atomic Energy Commission, Washington, D.C., February 1974, Wash. No. 1337-2.

14. Anderson, L. L., : Energy Potential from Organic Wastes - A Review of the Quantities and Sources, Bureau of Mines Information Circular 8549 . U.S. Dept. of the Interior, Washington, D.C. (1972).

15. Alrich, J. A., and Inman, R. E., Stanford Research Institute: Effective Utilization of Solar Energy to Produce Clean Fuel, NSF/RANN/SE/GI/38723/ $F R / 74 / 2$, June 1974 .

16. Beller, M., Brookhaven National Laboratory, National Center for Analysis of Energy Systems: Energy Cost Data, Internal Memorandum, March 1975.

17. The Conference Board: Energy Consumption in Manufacturing, Ballinger Publishing Co., Cambridge, Massachusetts, 1974.

18. Bravard, J. C. et al., Oak Ridge National Laboratory: Energy Expenditures Associated with the Production and Recycle of Metals, ORNL-NSF-EP-24, November 1972. 
19. U.S. Department of Commerce, Bureau of the Census, 1972 Census of Mineral Industries.

20. U.S. Department of the Interior, Bureau of Mines: Minerals Yearbook Volume I, 1970.

21. Makino, H. and Berry, R. S., 111 inois Institute for Environmental Quality: Consumer Goods--A Thermodynamic Analysis of Packaging, Transport, and Storage, June 1973.

22. Teasley, L. N., Washington University, St. Louis, Missouri: Energy Implications of Polymer Production and Use, M.S. Thesis, December 1974. 


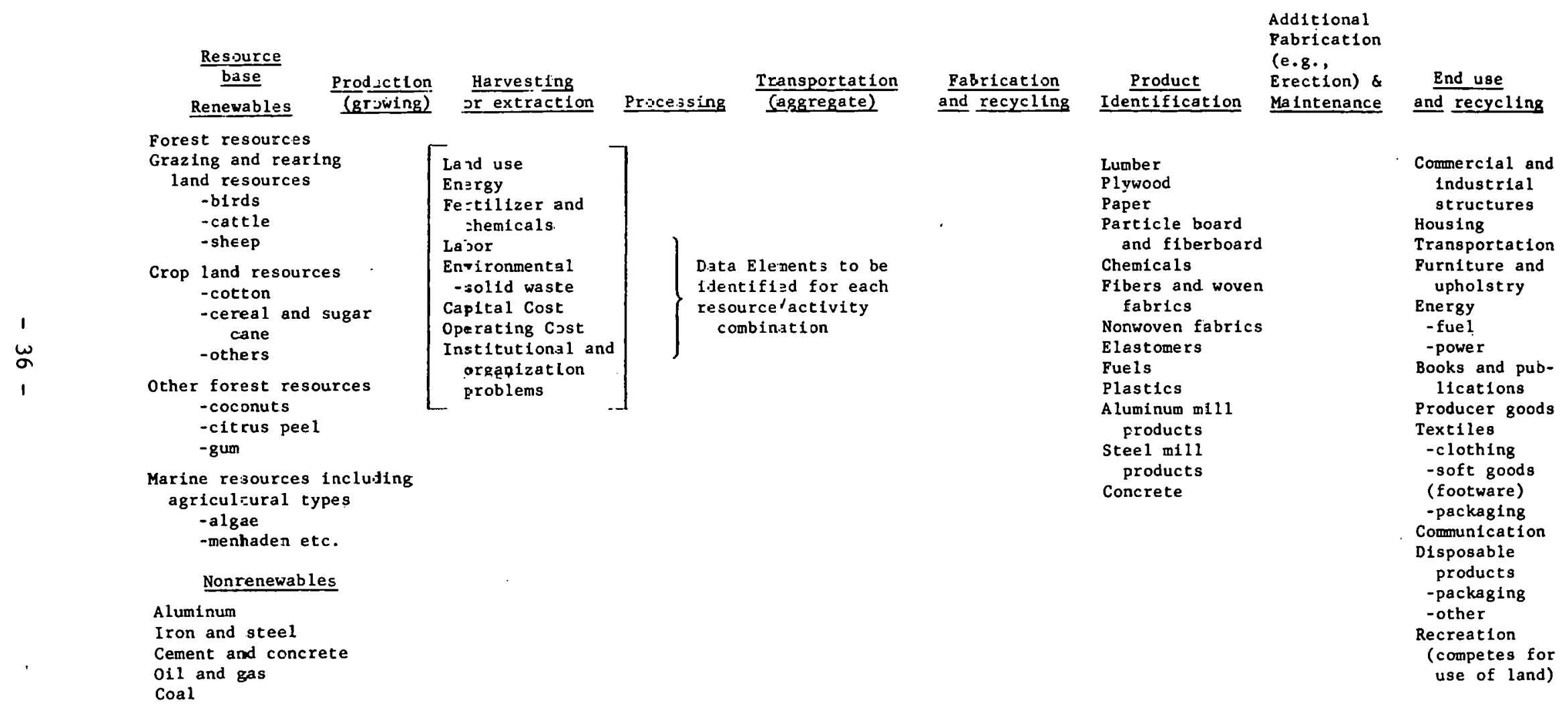

Figure 1. Scope of reference material system and associated data elements. 


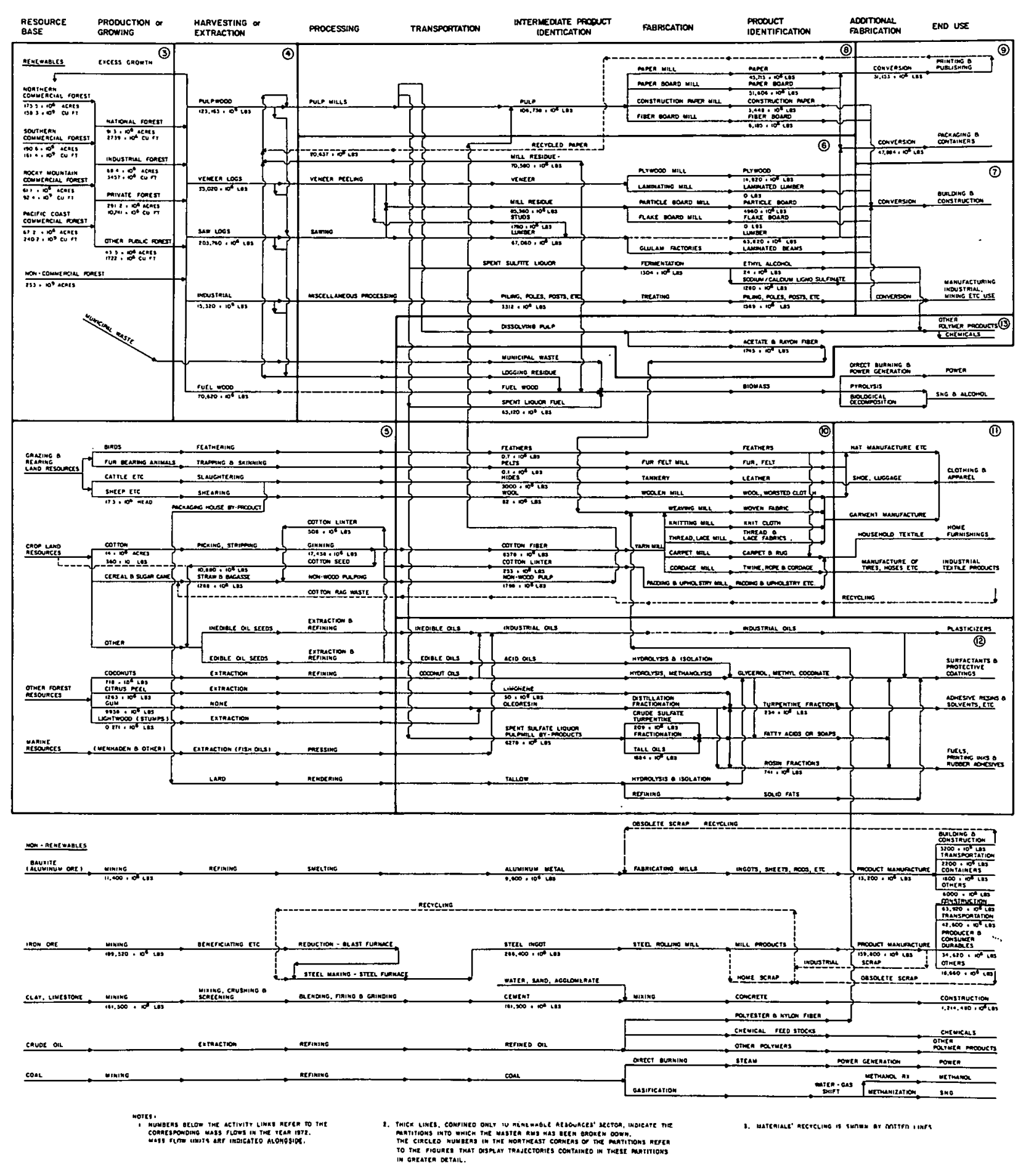

Figure 2. (Master) reference material system (1972). 


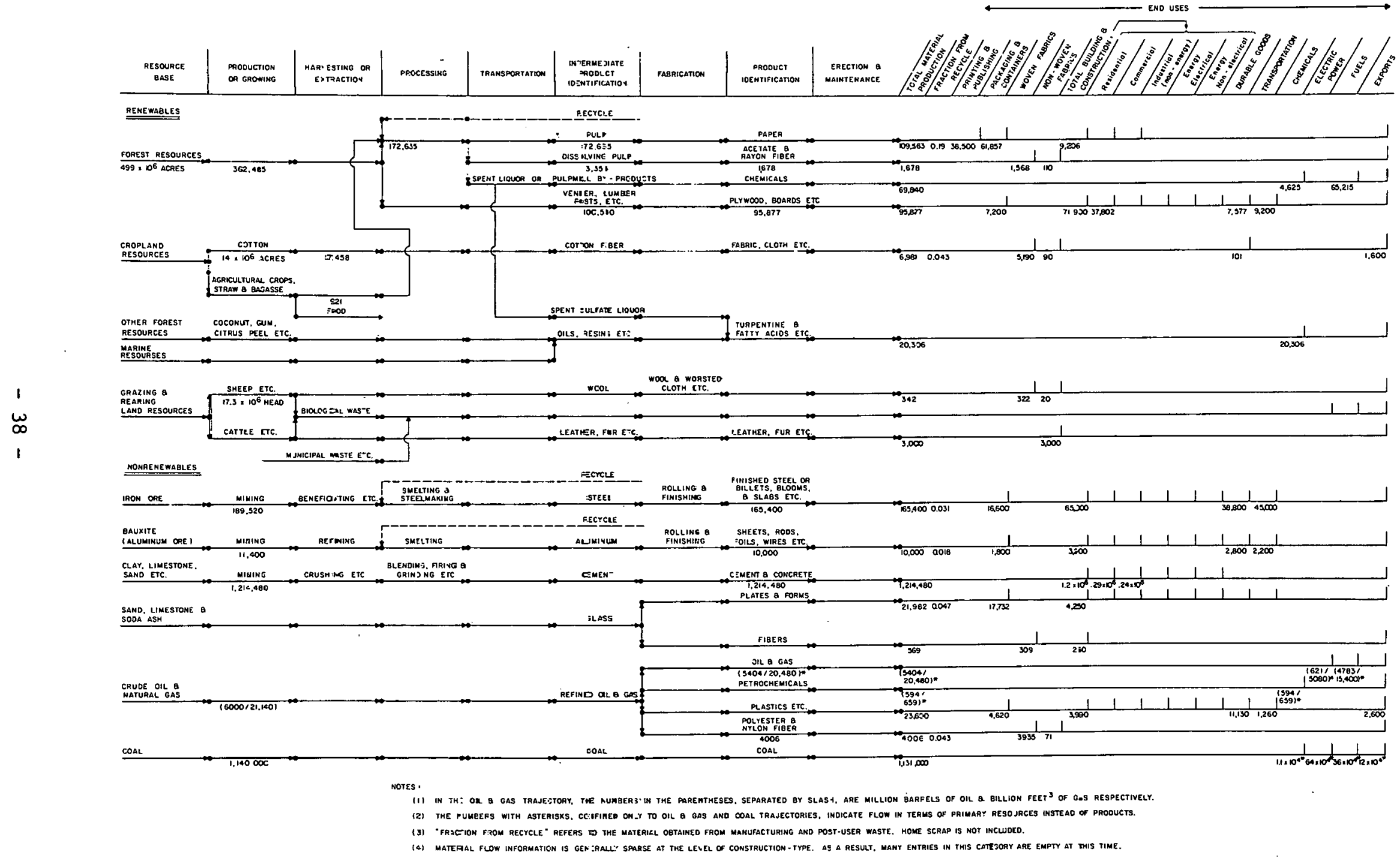

Figure 2A. Aggregate reference material system. Mass flow in million pounds (year 1972). 

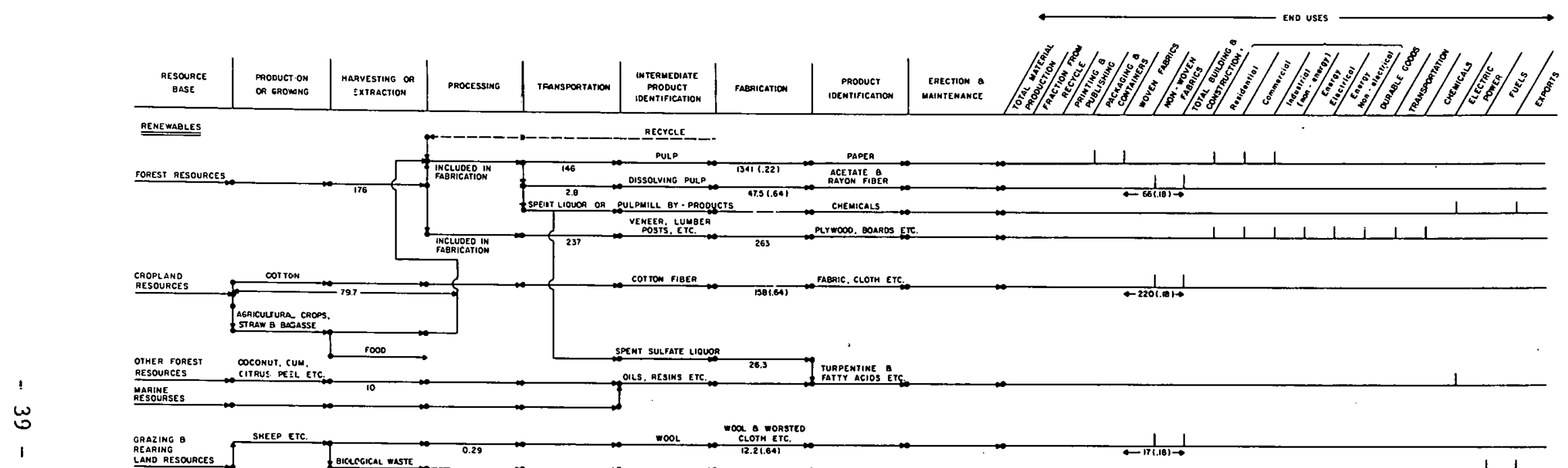

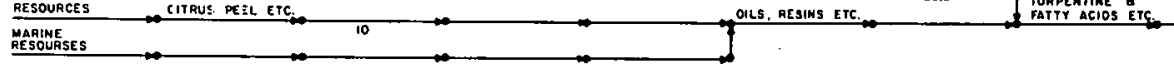

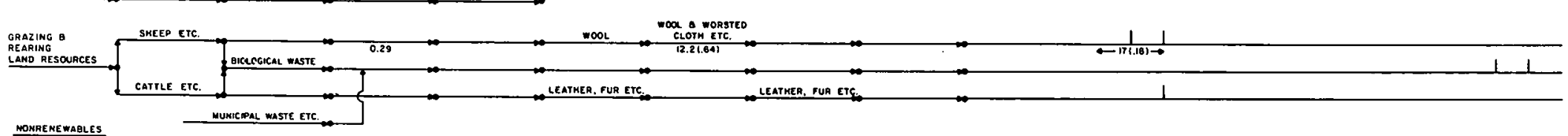




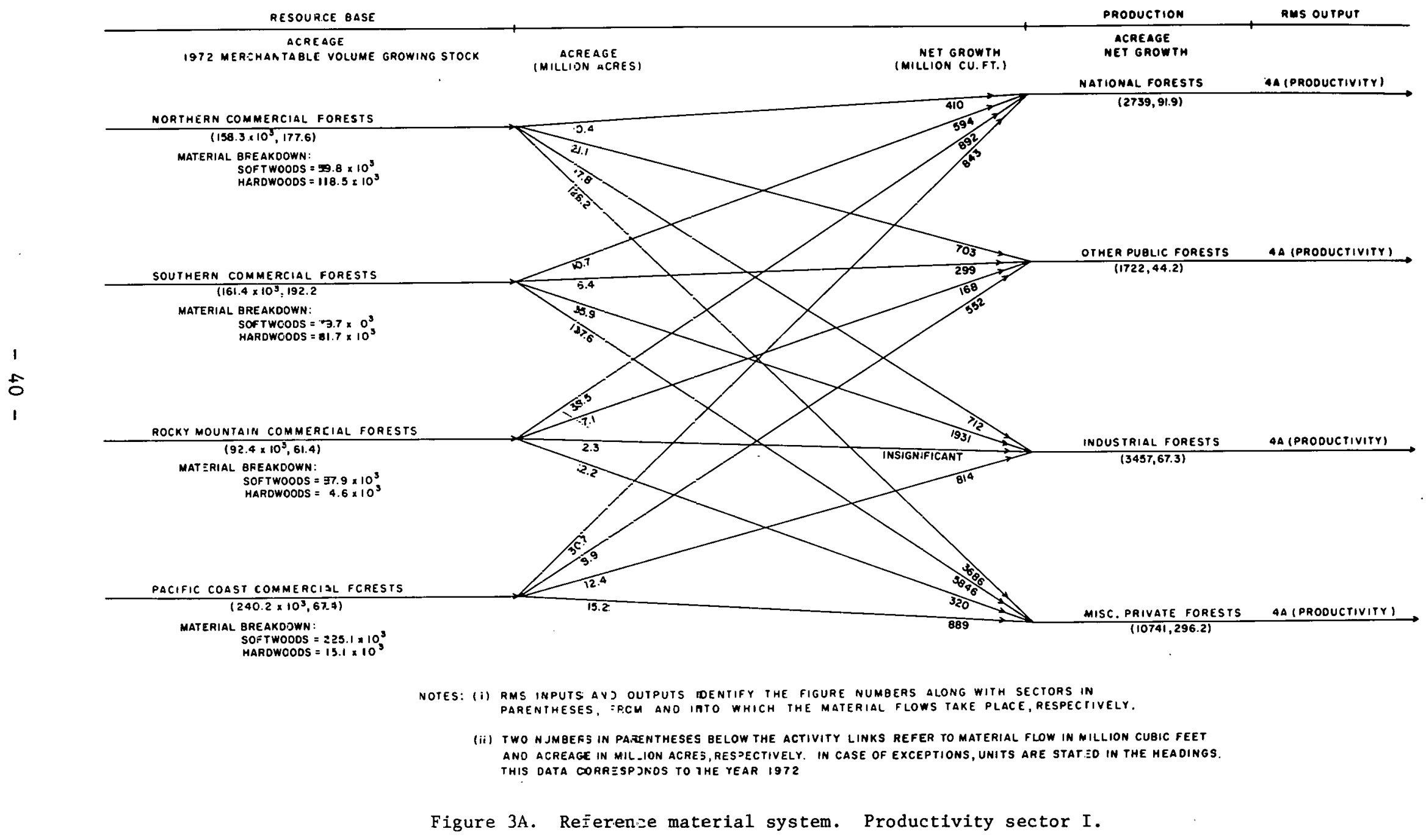




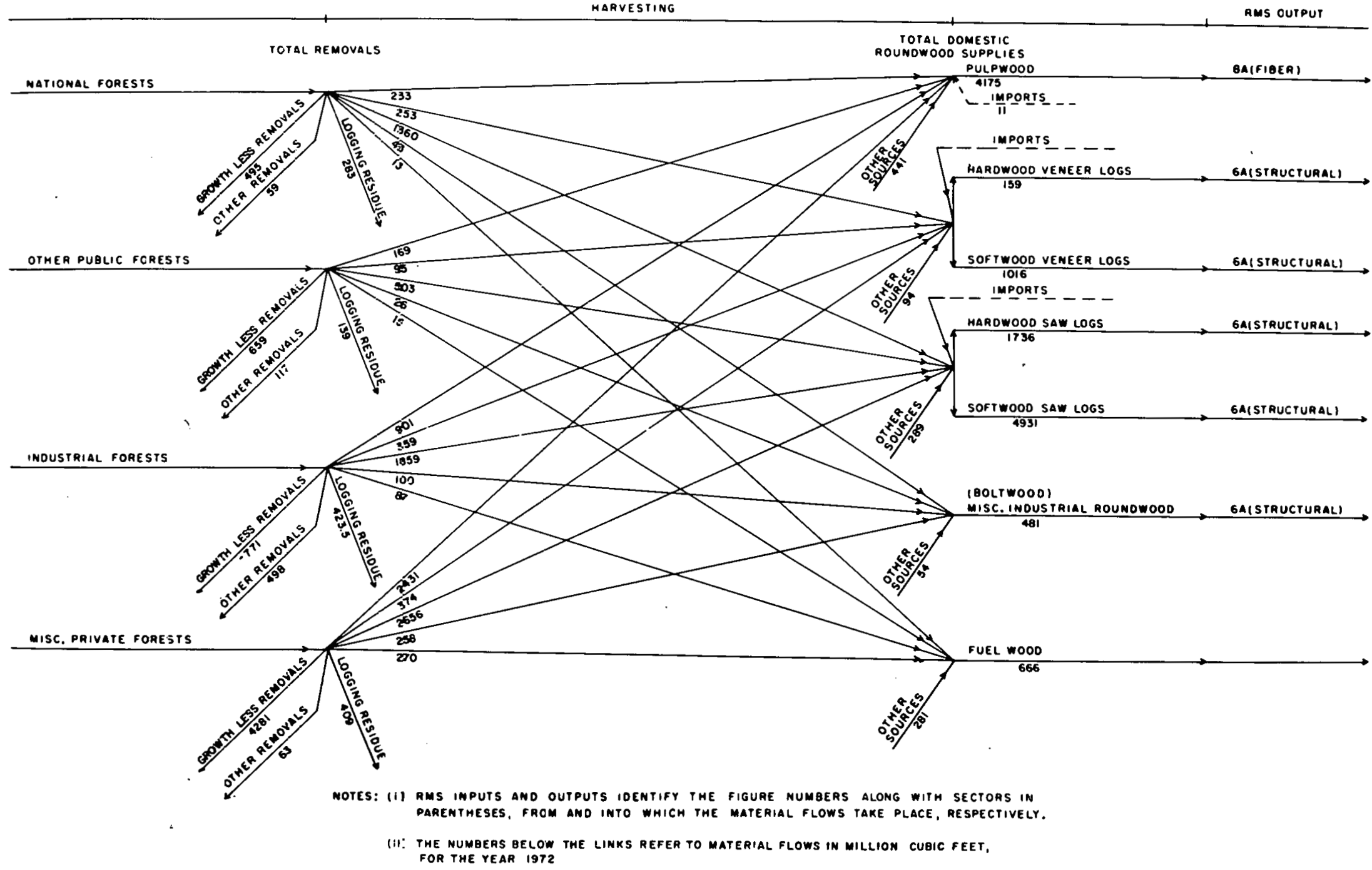

Figure 4A. Reference material system. Productivity sector II. 


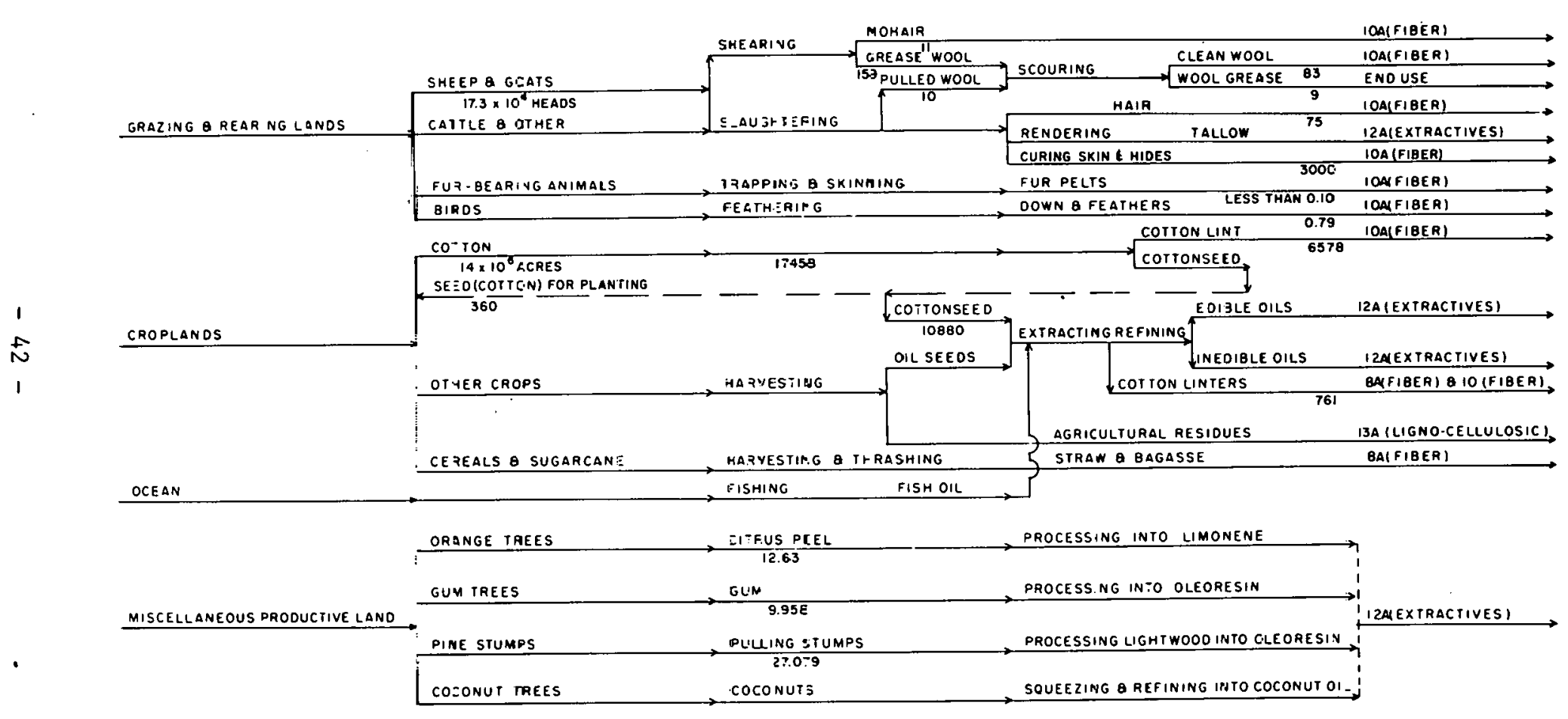

VOTES: (i) RMS INPUTS. AND OLTPUTS IOENTIFY THE FIGURE NUMBERS ALONG WITH SECTORS IN PARENTHESES, FROM ANO INTO WHICH THE MATERIAL FlOWS TAKE PLACE, RESPECTIVELY.

(ii) THE NUMBERS EELOW ACTIVITY LINKS REFER TO MATERIAL FLOWS IN MILLION POUNDS. OR AS INOICATEG. FOR THE YEAR I I ??

Figure 5A. Reference material system. Productivity sector III. 


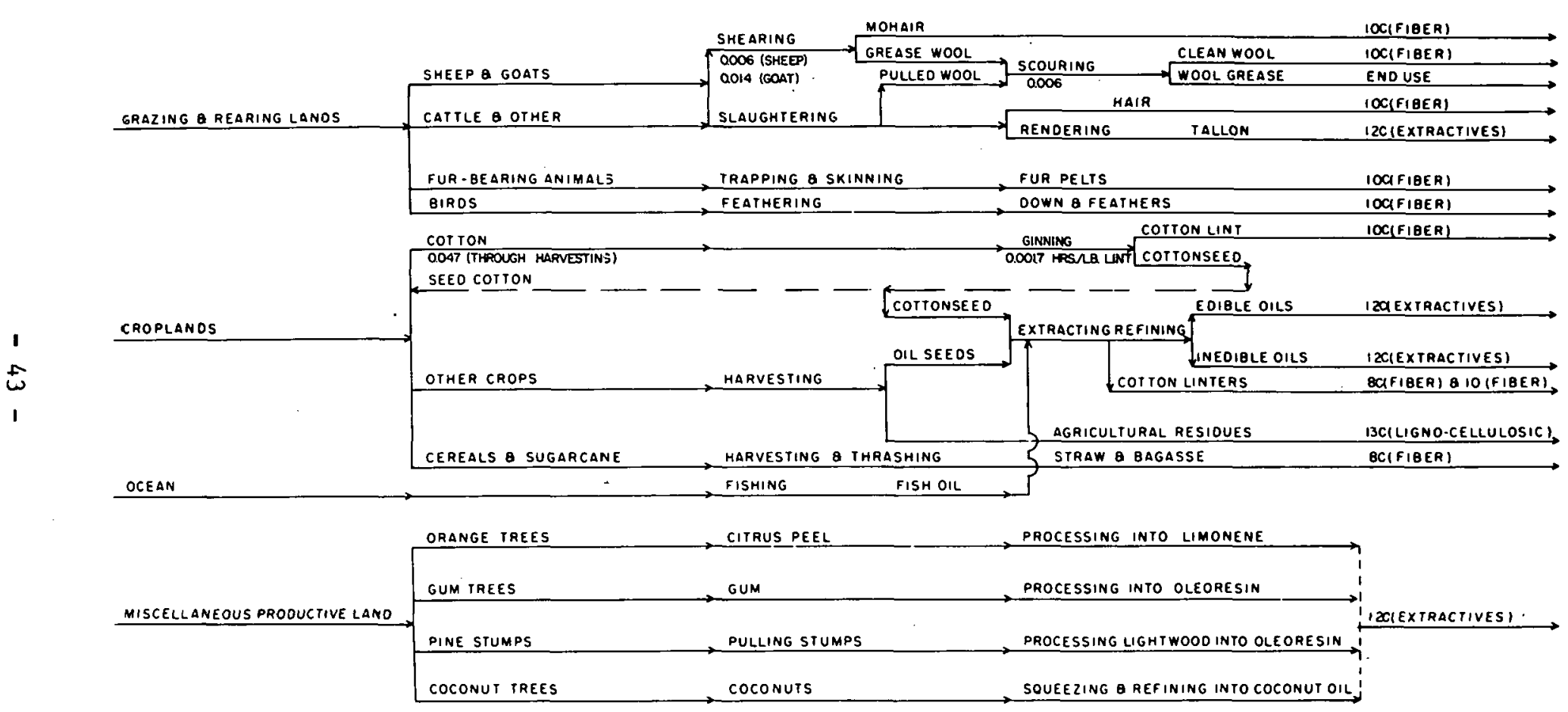

NOTES: (i) RMS INPUTS ANO OUTPUTS IDENTIFY THE FIGURE NUMBERS ALONG WITH SECTORS IN Parentheses, from and INTO Which the material flows take place, Respectively.

(:I) NUUMERS BEOW THE ACTIVITY LINKS REFER TO LABOR REOUIREMENT IN MAN-HOURS PER

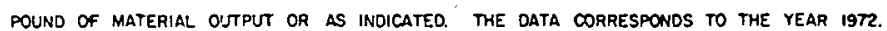

Figure 5C. Feference material system. Productivity sector III. 


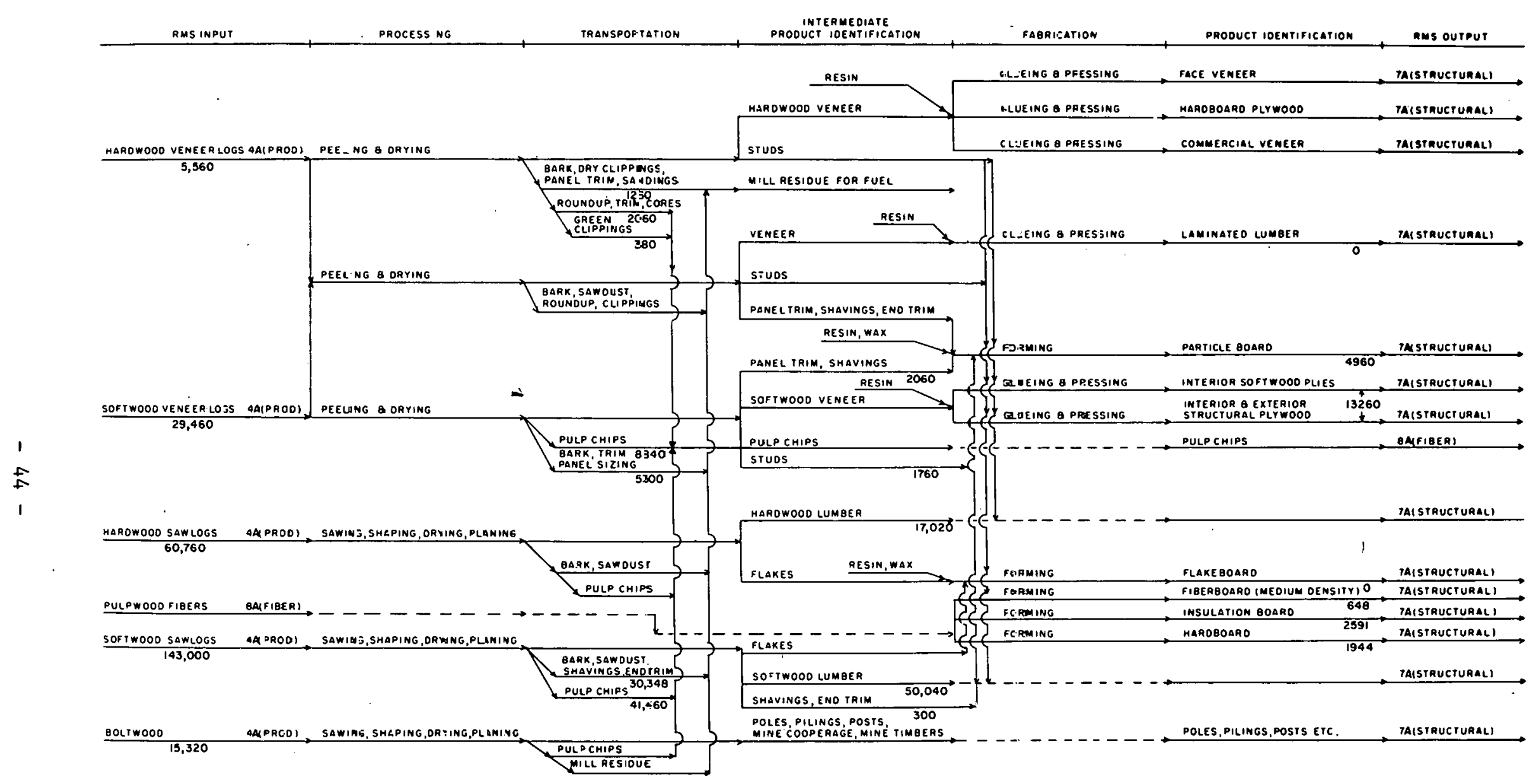

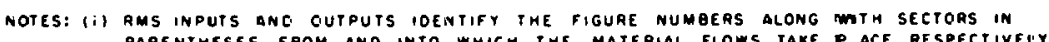

(II) THE NUMAERS BELOW ACTIVITY LIMKS REFER TO METERIAL FLOWS IN MILLION POUNOS,

FOR THE VEAE 1972

Figure 6A. Reterence material system. Structural sector 1 . 


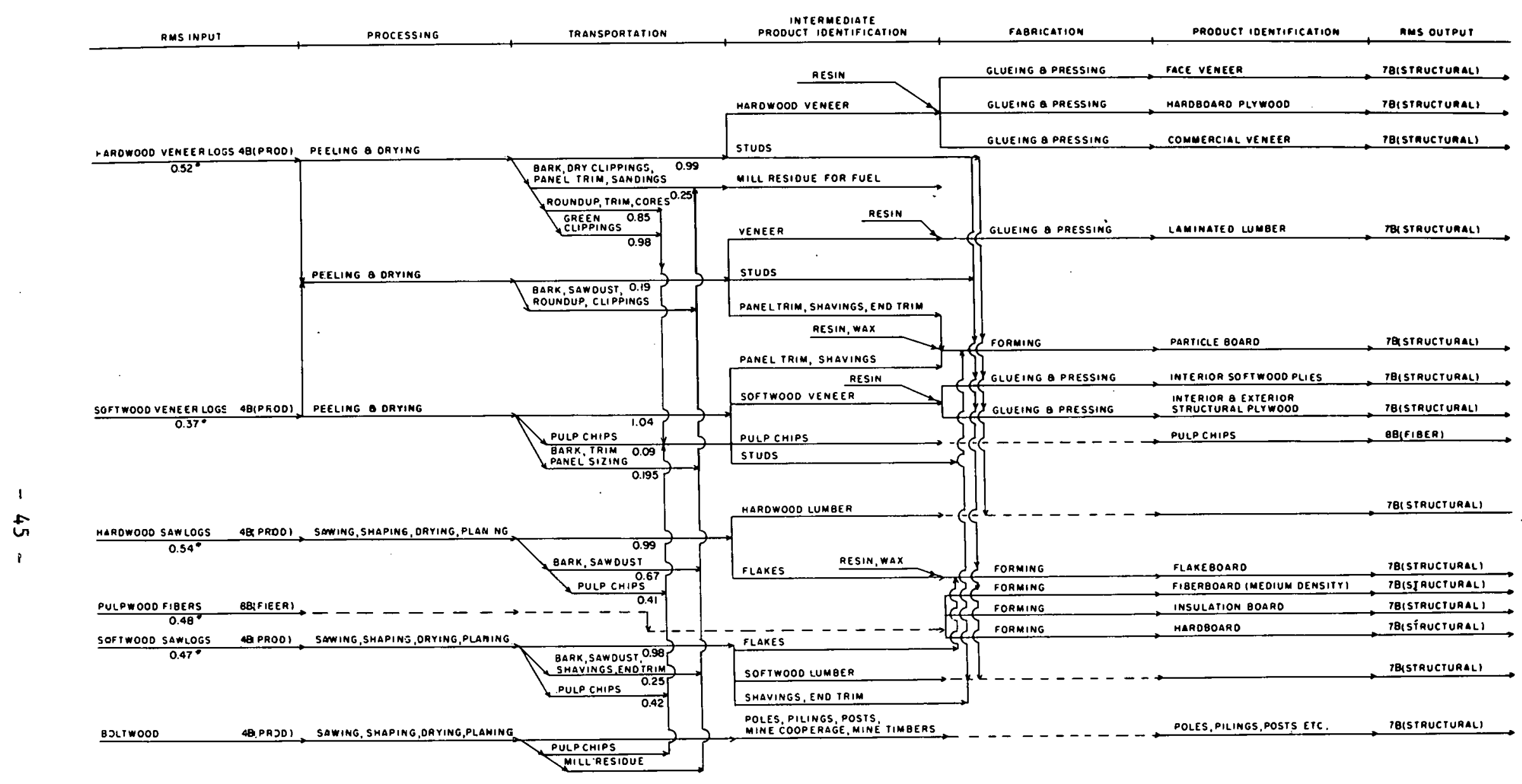

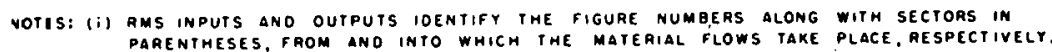

(ii) NUMBERS BELOW THE ACTIVITY LIMKS REFER TO ENERQY REOUIREMENT IN THOU3ANO BI.

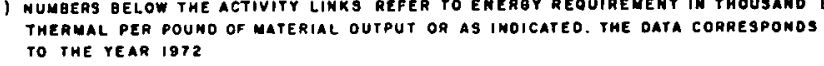

- these values oenote loggikg enepgr

Figure 6B. Reference material system. Structural sector I. 


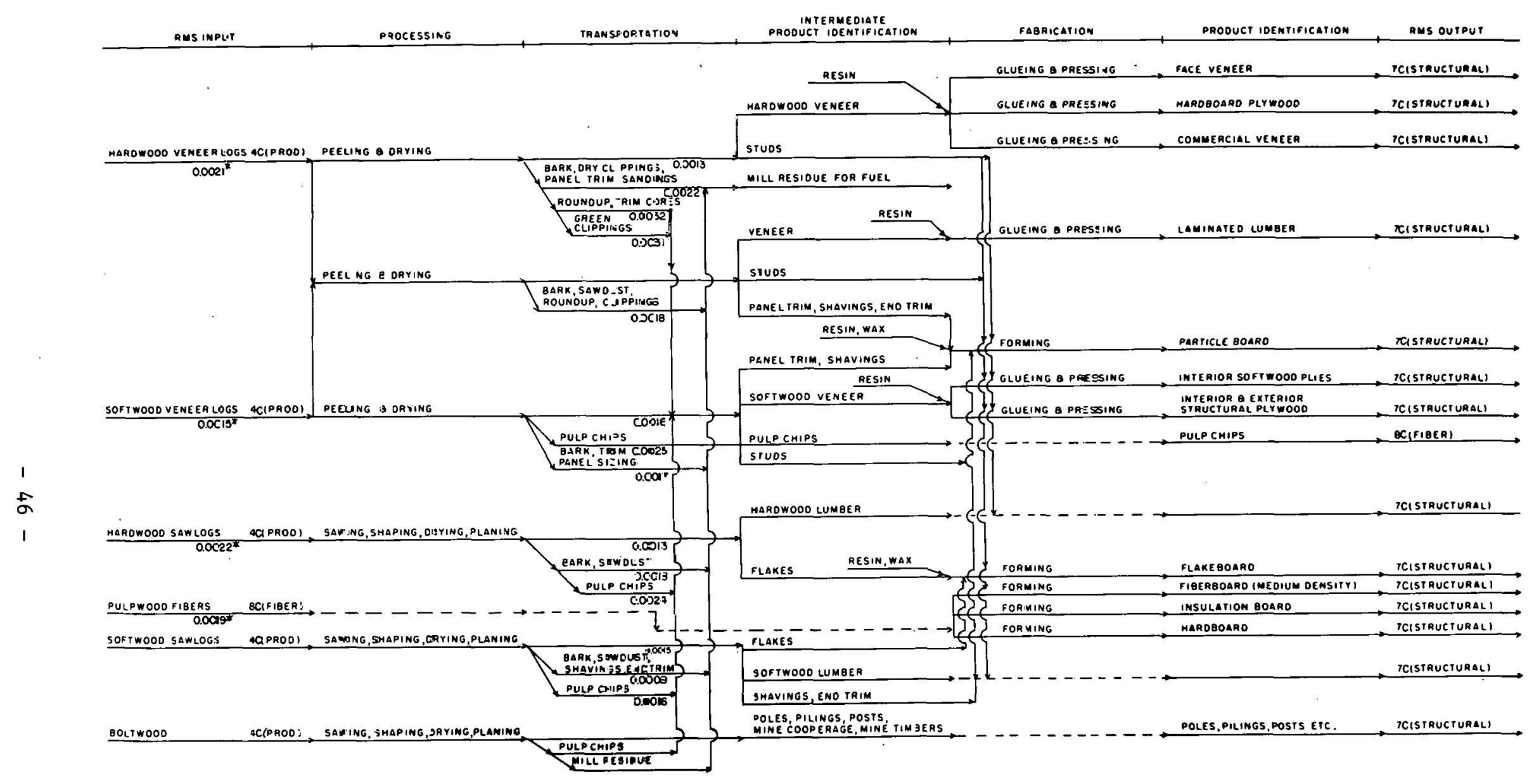

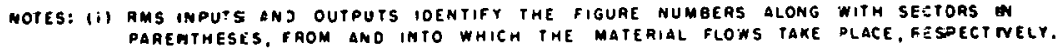

(ii) NUYEERS SEOW THE ACTVVITY LINKS REFER TO LABOR FEOUIREMENT IN M:AN-HOURS PER

POUNE OF NATERIAL OUTPUT OR AS INDICATED. THE DATA DORPESPONOS TO THE TaA I97a.

* thesc values denote labor reouirement for logging.

Figure 6C. ReFerence material system. Structural sector I. 


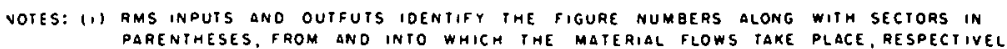

PARENTHESES, FROM AND INTO WHICH THE MATERIAL FLOHS TAKE PLACE, RESPECTIVE

pounjo of material output or as indicated. THe data cospespondos to the year ig7z.

* these values denote capital reouirement for logging

Figure 6D. Reference material system. Structural sector I. 


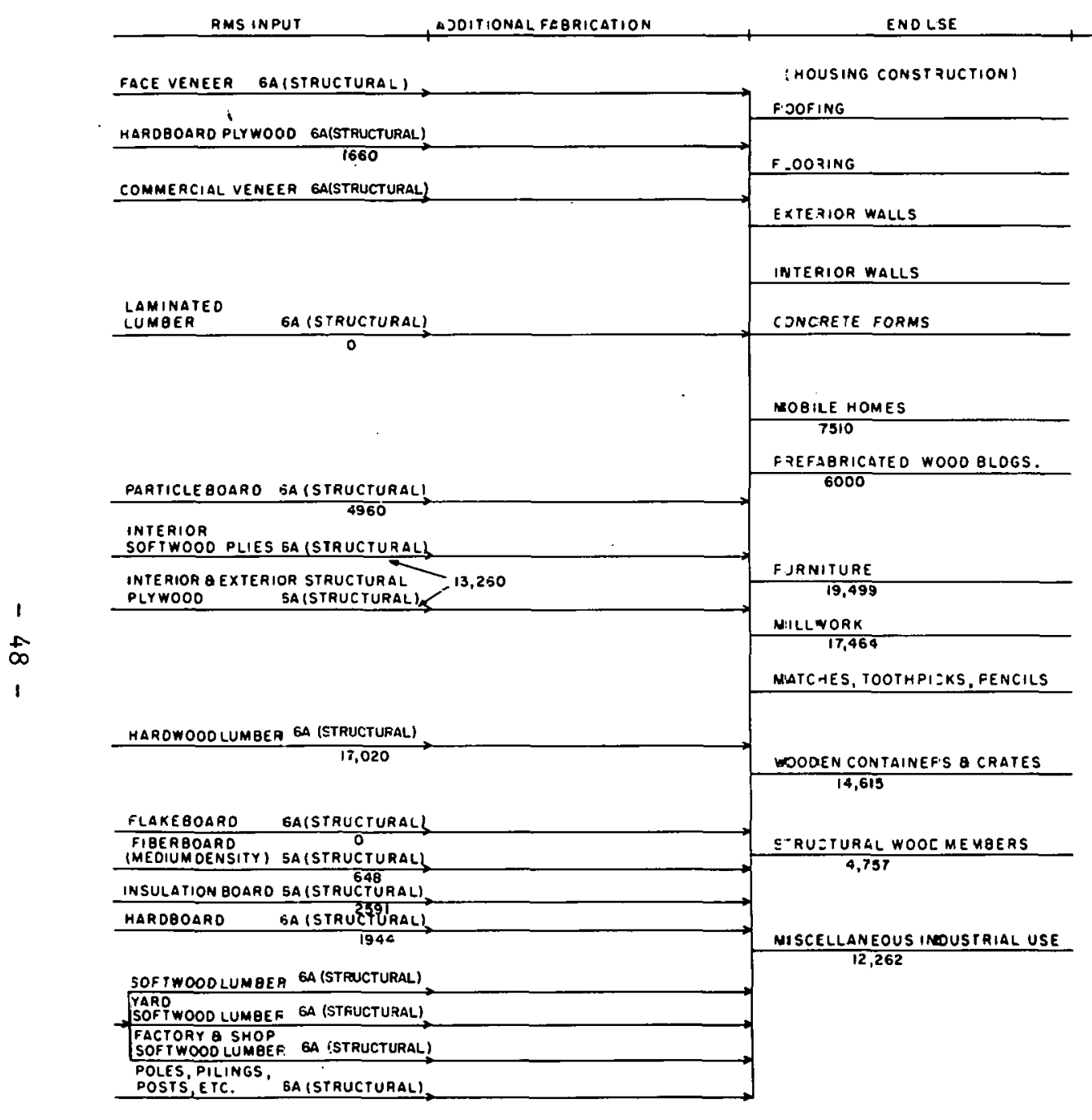

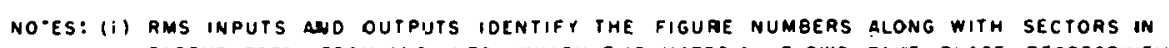
PARENTHESES, :ROM aND INTO WHICH THE MATERIAL FLOWS TAKE PLACE, RESPECTIUELY.

(ii) THE NUMEers LOW ACTIVITY LINKS REFER tO MATERIAL FLOWS IN MILLION POUNDS, FOR THE YEAR 197

Figure 7A. Reference matærial system. Structural sector II. 


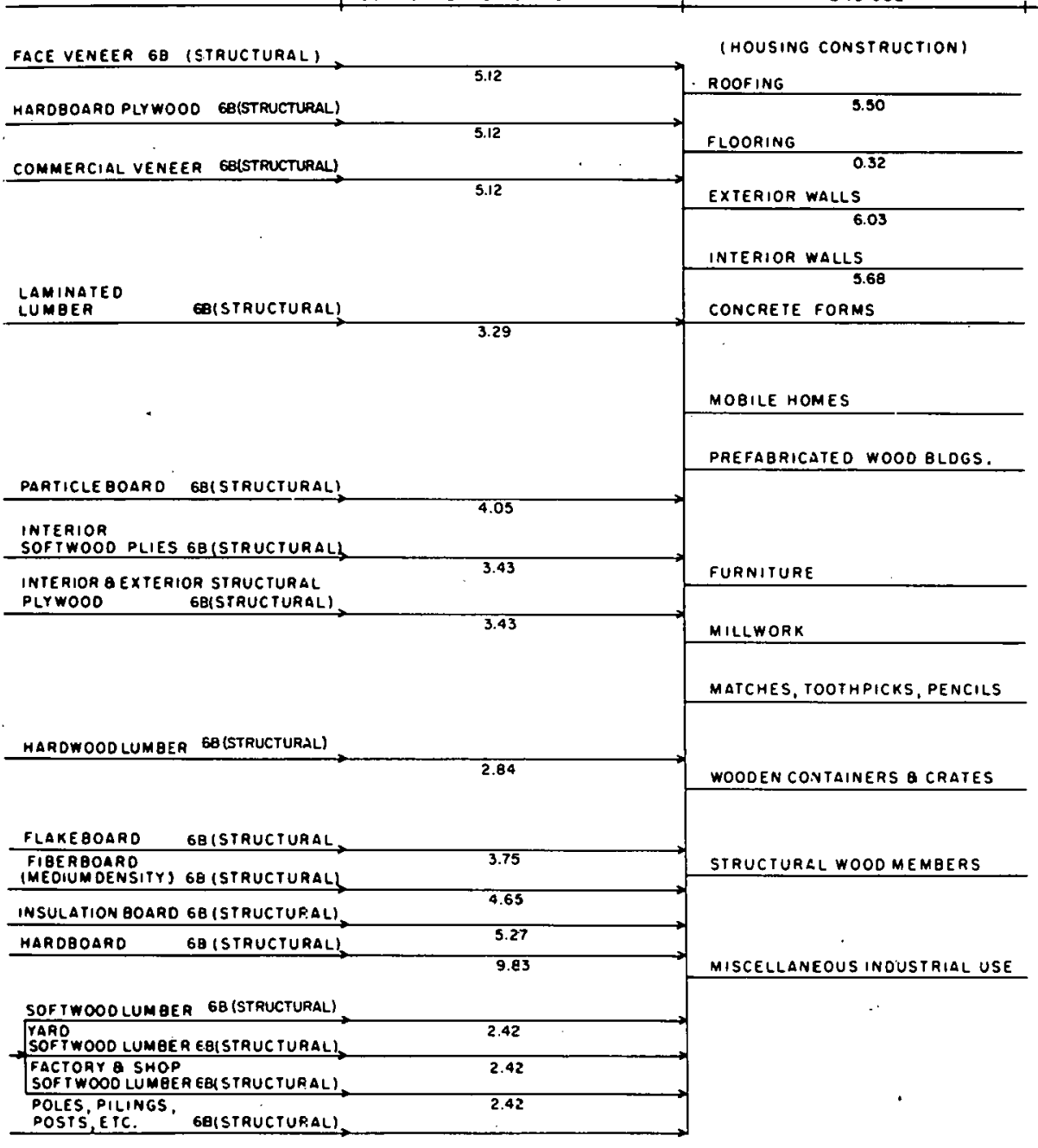

NOTES: (iI RHS INPUTS ANO OUTPUTS IOENTIFY THE FIGURE NUMBERS ALONG WITM SECTORS IN parentheses, from ano into Which the material flows take place, respectively.

(ii) NUMBERS geLOW THE ACTIVITY LINKS REFER TO ENERGY REQUIREMENT IN THOUSANO

BIU THERMAL PER POUND OF MATERIAL OUTPUT OR AS INOICATED. THE DATA CORRESPONDS

TO THE YEAR 1972

Figure 7B. Reference material system. Structural sector II. 
RMS INPUT

ENO USE

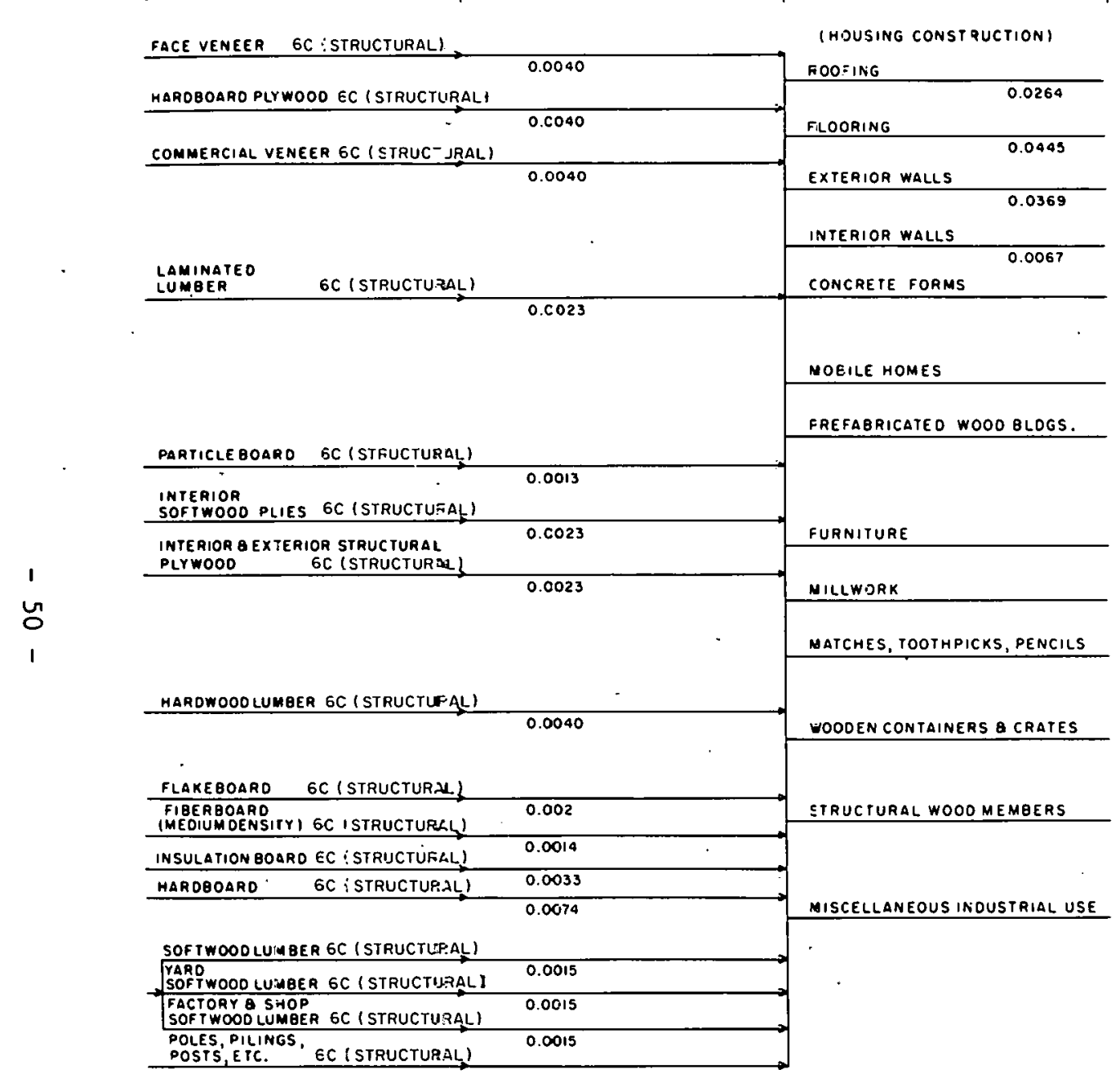

NOTES: :i) RMS INPU:S AND OUTPUTS IOENTIFY the FIGURE NUMBEas along With SECTORS IN PARENTHESES, FROM AND INTO WHICH THE MATERIAL FLOWS TAKE PLACE, RESPECTIVELY.

(ii) NUMBES REOW THE ACTIVITY LINKS REFER TO LABOR REOUIREMENT IN MAN-HOURS PER

POUND Of MaTER OUTPUT OR AS RNDICATED TME DATA CORPESPONDS TO TME YEAR 1972.

Figure 7C. Reference material system. Structural sector II. 


\begin{tabular}{|c|c|c|}
\hline \multicolumn{2}{|l|}{ 6D(S:RLCTURAL) } & \multirow{2}{*}{$\begin{array}{l}\text { (HOUSING CONSTRUCTION) } \\
\text { ROOFING }\end{array}$} \\
\hline \multirow[b]{2}{*}{ HAROBOARO PLYWOOO 6D I STRUCTURALI } & \multirow{2}{*}{9.18} & \\
\hline & & 46.78 \\
\hline \multirow{2}{*}{ 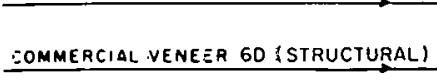 } & \multirow[t]{2}{*}{9.18} & \multirow{3}{*}{$\begin{array}{l}\text { FLOORING } \\
\text { EXTERIOR WALLS }\end{array}$} \\
\hline & & \\
\hline \multirow{4}{*}{$\begin{array}{l}\text { LAMINATEO } \\
\text { LUMBER } \\
\end{array}$} & \multirow[t]{3}{*}{9.18} & \\
\hline & & \multirow{2}{*}{$\begin{array}{l}72.80 \\
\text { INTERIOR WALLS } \\
\text { CONCRETE FORMS }\end{array}$} \\
\hline & & \\
\hline & \multirow[t]{4}{*}{5.99} & \multirow[b]{2}{*}{ MOBILE HOMES } \\
\hline \multirow[b]{3}{*}{ PARIICLE BOARD 6D (STRUCTURAL) } & & \\
\hline & & PREFAERICATEO WOOO BLDGS. \\
\hline & & \multirow{2}{*}{ FURNITURE } \\
\hline $\begin{array}{l}\text { INTERIOR } \\
\text { SOFTWOOD PLIES 6D (STRUCTURAL) }\end{array}$ & 6.87 & \\
\hline $\begin{array}{l}\text { INTERIOR a EXTERIOR STFUCTURAL } \\
\text { PLYWOOD OD (STRUCTURAL) } \\
\end{array}$ & 6.04 & \multirow[b]{2}{*}{ MILLWORK } \\
\hline & \multirow[t]{2}{*}{6.04} & \\
\hline & & MATCMES, TOOTHPICKS, PENCILS \\
\hline \multicolumn{2}{|l|}{ MARDWOODLUMBEA 60 (STRUCTURAL) } & \multirow[b]{2}{*}{ WOOOEN CONTAINERS Q CRATES } \\
\hline & \multirow[t]{2}{*}{13.03} & \\
\hline GDisTRUCTURAL) & & \multirow{2}{*}{ STRÜCTURAL WOOO MEMEEERS } \\
\hline $\begin{array}{l}\text { FIEEREOAARO } \\
\text { (MEOIUMDENSITY) } 60 \text { (ITRUCTURAL) }\end{array}$ & 5.68 & \\
\hline INSULATION BOARO 60 (STRUCTURAL) & 13.94 & \multirow[b]{3}{*}{ MISCELLANEOUS INDUSTRIAL USE } \\
\hline \multirow[t]{2}{*}{ HAROBOARO $\quad$ 60 (STRUCTURAL) } & 12.03 & \\
\hline & 24.04 & \\
\hline \multicolumn{2}{|l|}{ SOF TWOODLUM BER $6 D$ (SIRUCTURAL) } & \\
\hline$\sqrt{\text { YARO }}$ SOFTWOOD LUMBER 60 :STRUCTURAL) & 1.95 & \\
\hline $\begin{array}{l}\text { FACTORY B SHOP } \\
\text { SOFT WOOOLUMBER } 60 \text { (STRUCTURAL) }\end{array}$ & 1.95 & \\
\hline $\begin{array}{l}\text { POLES, PILINGS, } \\
\text { POSTS,ETC. }\end{array}$ & 1.95 & \\
\hline
\end{tabular}

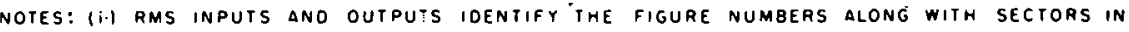
parentheses, from and into which the material flows take place, respectively.

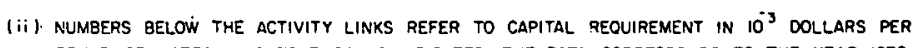

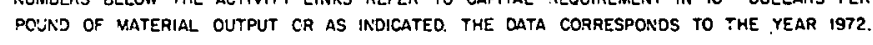

Figure 7D. Reference material system. Structural sector II. 


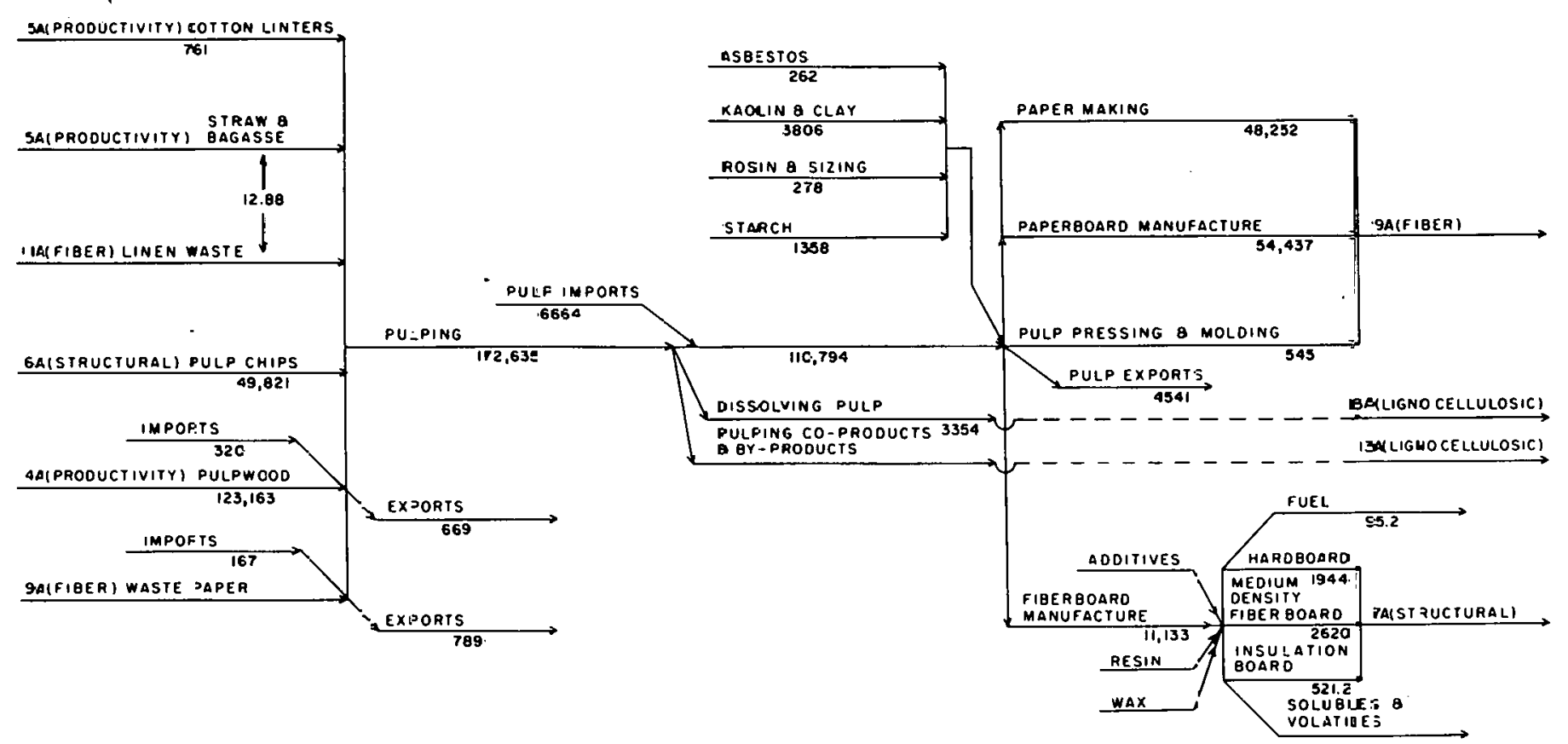

NOTES: (i) RMS INPUTS ANO OUTPUTS IOENTIFY THE FIGURE NUMBERS ALONG WITH SECTJRS IN RMS INPUTS ANO OUTPUTS IOENTIFY THE FIGURE NUMBERS ALONG WITH SECTJRS IN
PAREN HESES, FROM ANE INTG WHICH THE MATERIAL FLOWS TAKE PLACE, RESPECTIVELY.

(ii) THE NLMgERS BELOW ACTIVITY L'NKS REFER TO MATERIAL FLOWS IN MILLION POUNOS, FOR TOE YEAR 1972

Figure BA. Reference material system. Fibers (puIp \& paper) sector I. 
RMS INPUT

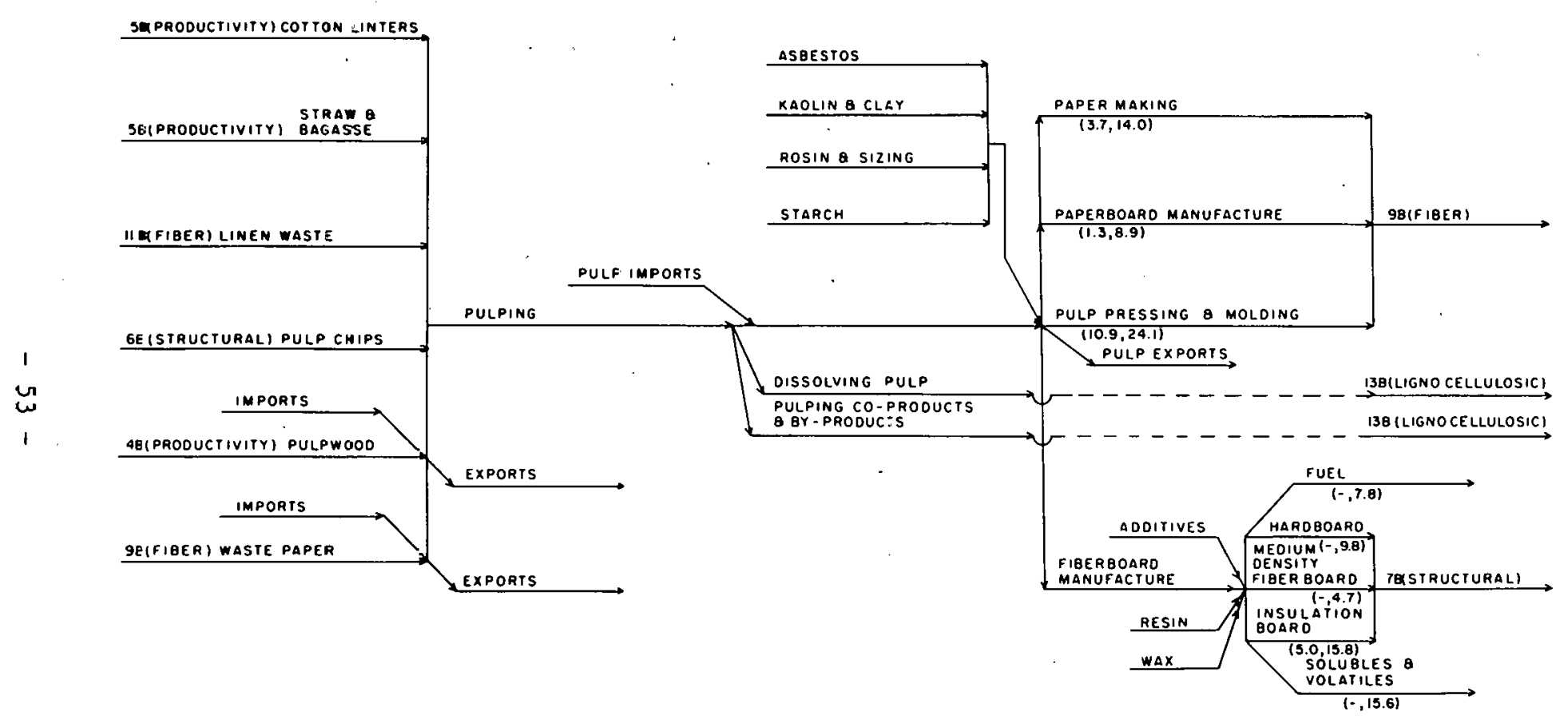

NO- ES: (i) RMS INPUTS ANC OUTPUTS IOENTIFY THE FIGURE NUMOERS ALONG WITH SECTORS IN
PARENTMESES, FROM ANO INTO WHICH THE MATERIAL FLOWS TAKE PLACE, RESPECTIVELY

(ii) TWO NUMAERS IN PARENTHESES BELOW THE ACTIVITY LINKS REFER TO ELECTRICAL a TOTAL ENERGY FEOUIREMENT RESPECTIVELY, IN THOUSANO BIU THERMAL PER POUND OF MATEZIAL OUTPUT OR AS INOICATEO. THE OATA CORRESPONDS TO THE YEAR 1972

(lii) ENERGY CONSUMED IN PAPER AND BOARD MANUFACTURE INCLUDES PULPING ON SITE

Figure 8B. Reference material system. Fibers (pulp \& paper) sector I. 


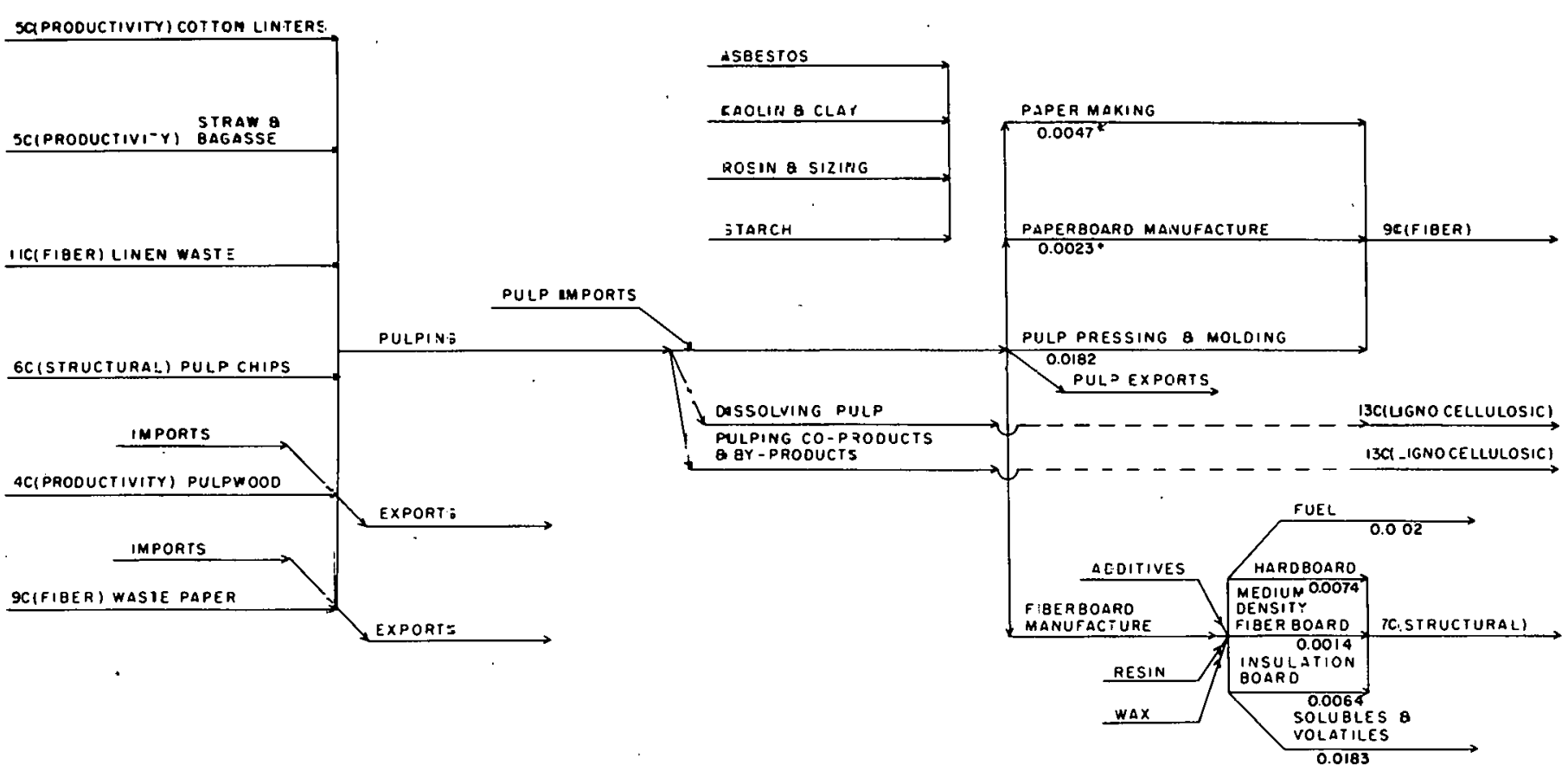
PAQ:NTHESES. FROM LND INTO WHICH THE MATERIAL FLOWS TAKE PLACE, RESPECTIVELY

-il) NUYEERS BELW THE ACTIVITY LI.KS REFER TO LABOR REDUIREMENT IN MAN-HOURS JER POUHD OF MATERIEL OUTPLT OR AS ImOICATED. THE DATA DORRESPONOS TO THE YEAR 1972.

- manuours per pound of paper es bocrd includes pulpins on site. adoitional total MANHOUAS USED IN PULPMILLS EOLAL $7.6 \times 10^{\circ}$

Figure 8C. Reference nacerial system. Fibers (pulp \& paper) sector I. 


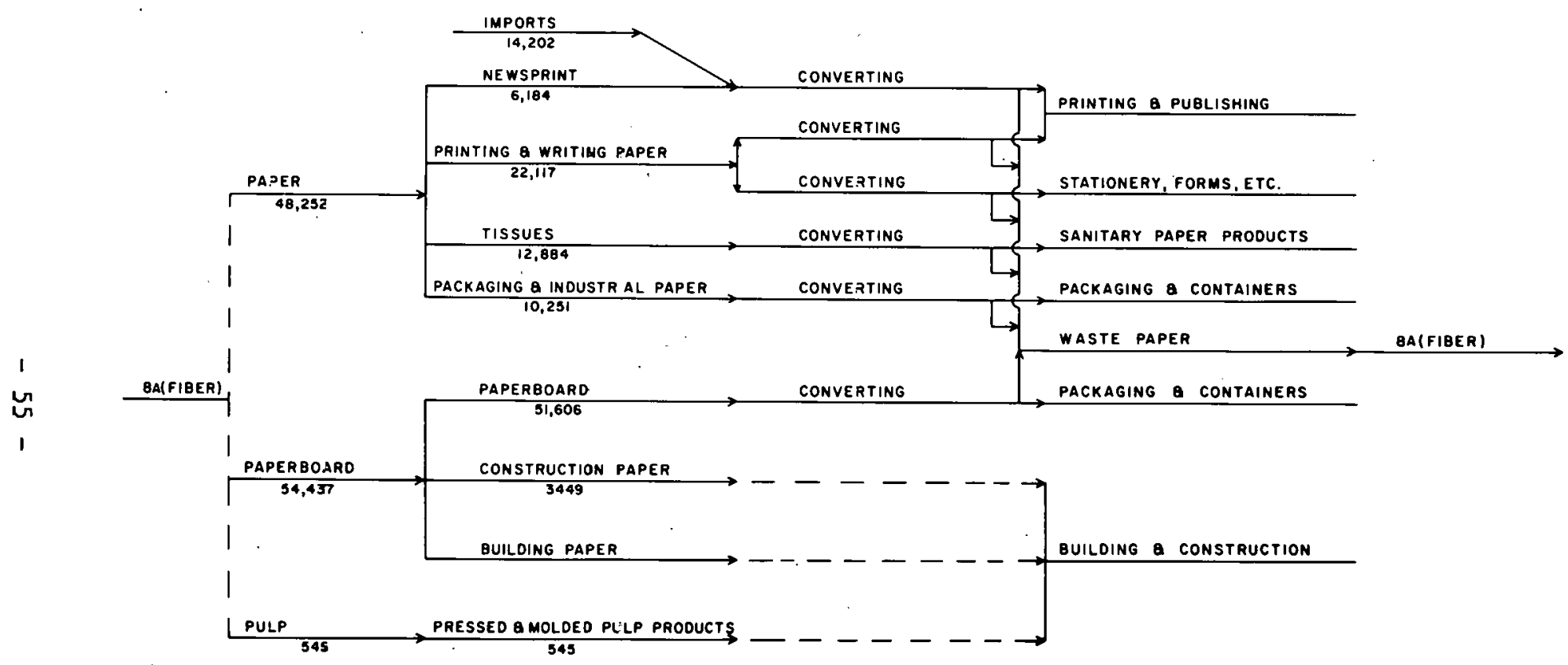

NOTES: (i) RMS INPUTS AND OUTPUTS IOENTIFY THE FIGURE NUMBERS ALONG WITH SECTORS IN

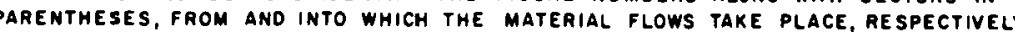

(ii) THE NUMBERS BELOW ACTIVITY L'INKS REFER tO MATERIAL FLOWS IN MILLION POUNOS, FOR THE YEAR 1972

Figure 9A. Reference material system. Fibers (pulp \& paper) sector II. 


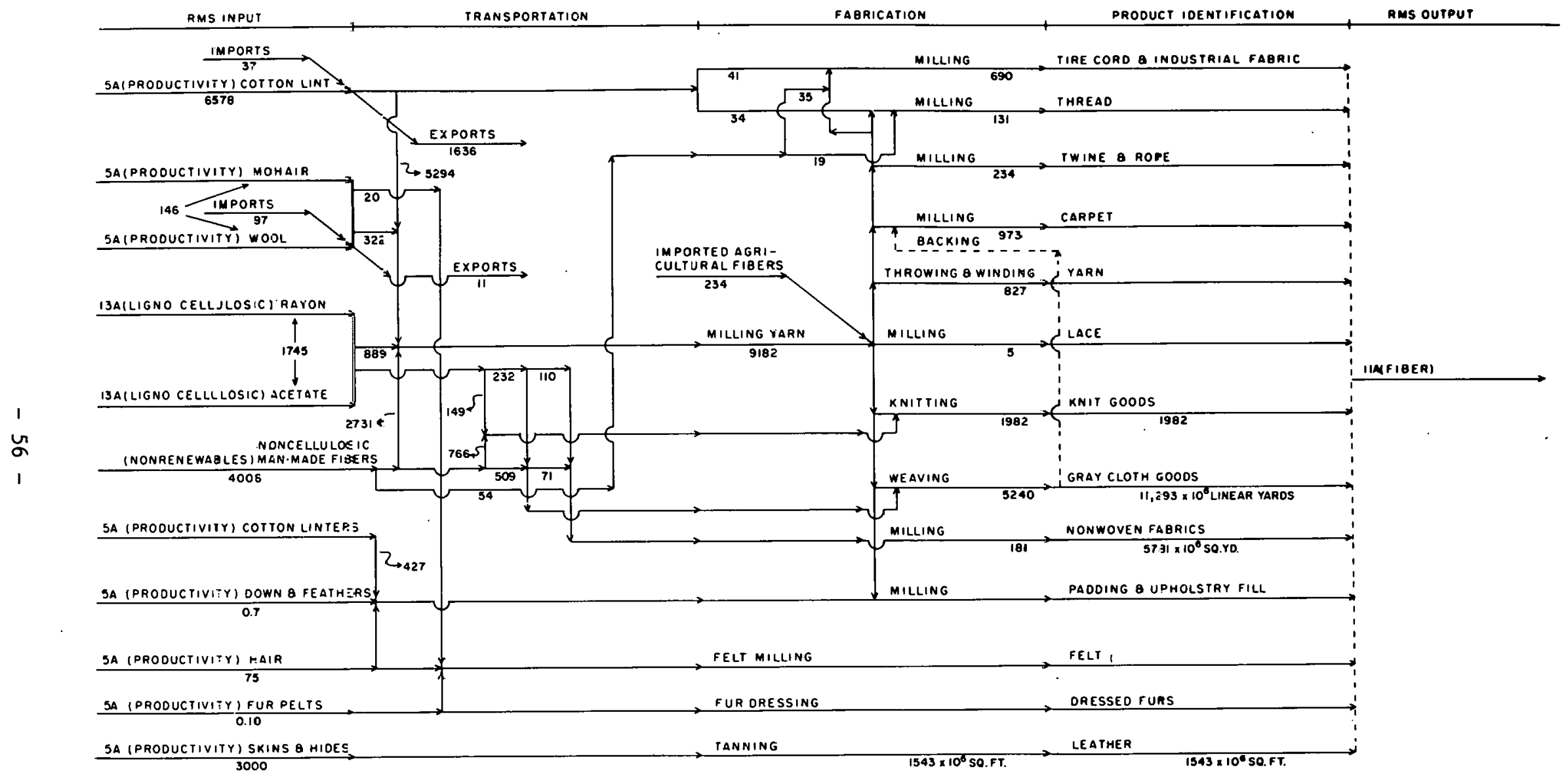

VOTES: (i) RMS INPUTS ANO OUTPUTS IOENTIFY THE FIGURE NUMBERS ALONG WITH SEC:ORS IN
FARENTHESES, FROM AND INTO WHICH THE MATERIAL FLOWS TAKE PLACE, RESPECTIVELY.

(ii) THE NUMBERS QELOW ACTI. ITY LINKS REFER TO MATERIAL FLOWS IN MILLION POUNDS,
SOR THE YEAR I9T2

Iigure 10A. Reference material system. Fibers (textiles \& apparel) sector III. 


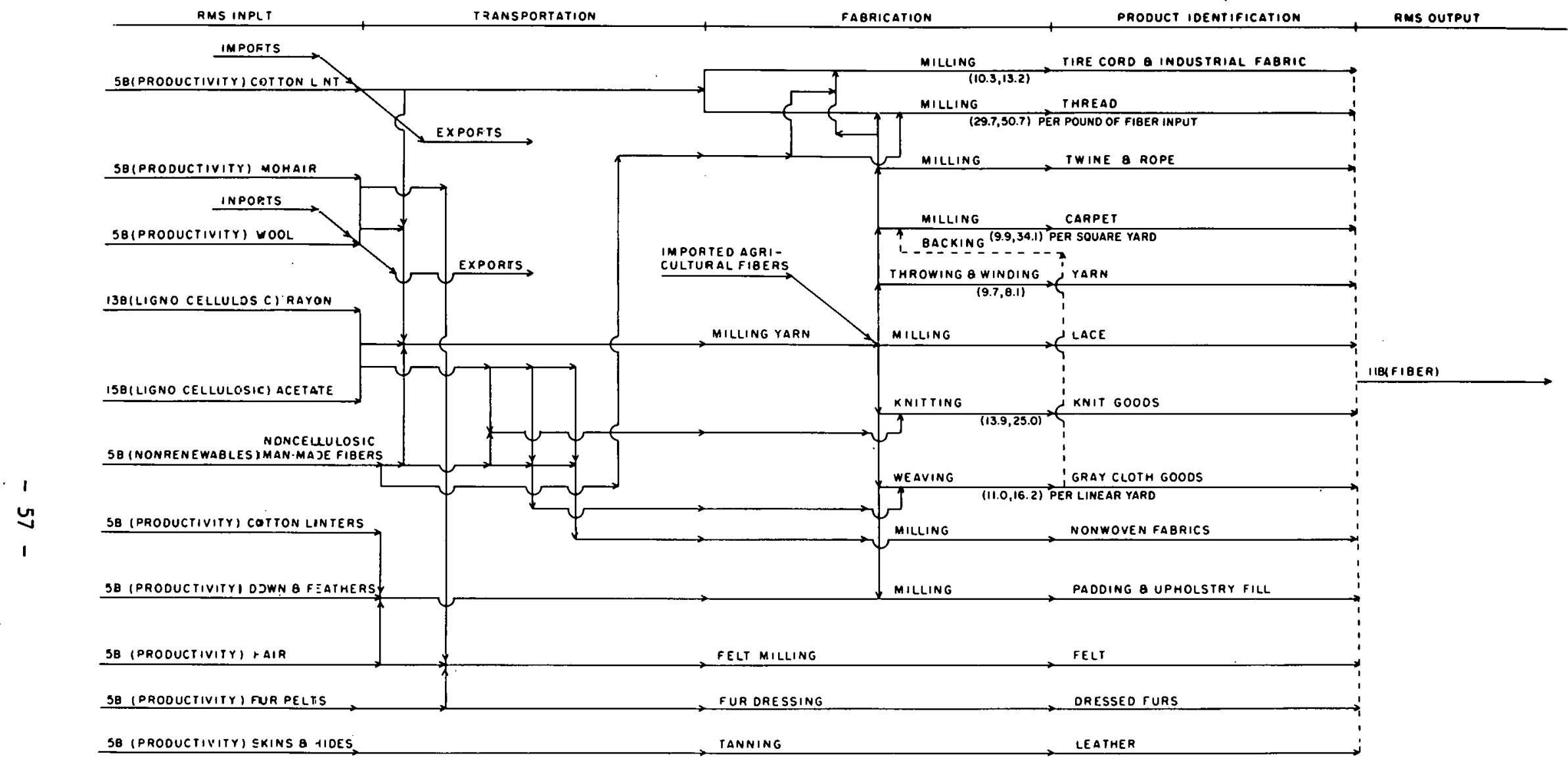

NOTES: (i) RMS INPUTS AND OUTPUTS IOENTIFY THE FIGURE NUMQERS ALONG WITH SECTORS IN
PARENTHESES, FROM AND INTO WHICH THE MATERIAL FLOWS TAKE PLACE, RESPECTIVELY

(ii) TWO NUMBERS IN PARENTHESES gELOW THE ACTIVITY LINKS REFER TO ELECTRICAL a

TOTAL ENERGY REOUIREMENT RESPECTIVELY, IN THOUSAND B IU THERMAL PER

POUND OF MATERIAL OUTPUT ORAS INDICATED. THE DATA CORRESPONOS TO THE YEAR 1972

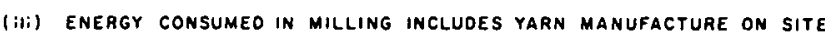

Figure 10B. Reference material system. Fibers (textiles \& apparel) sector III. 


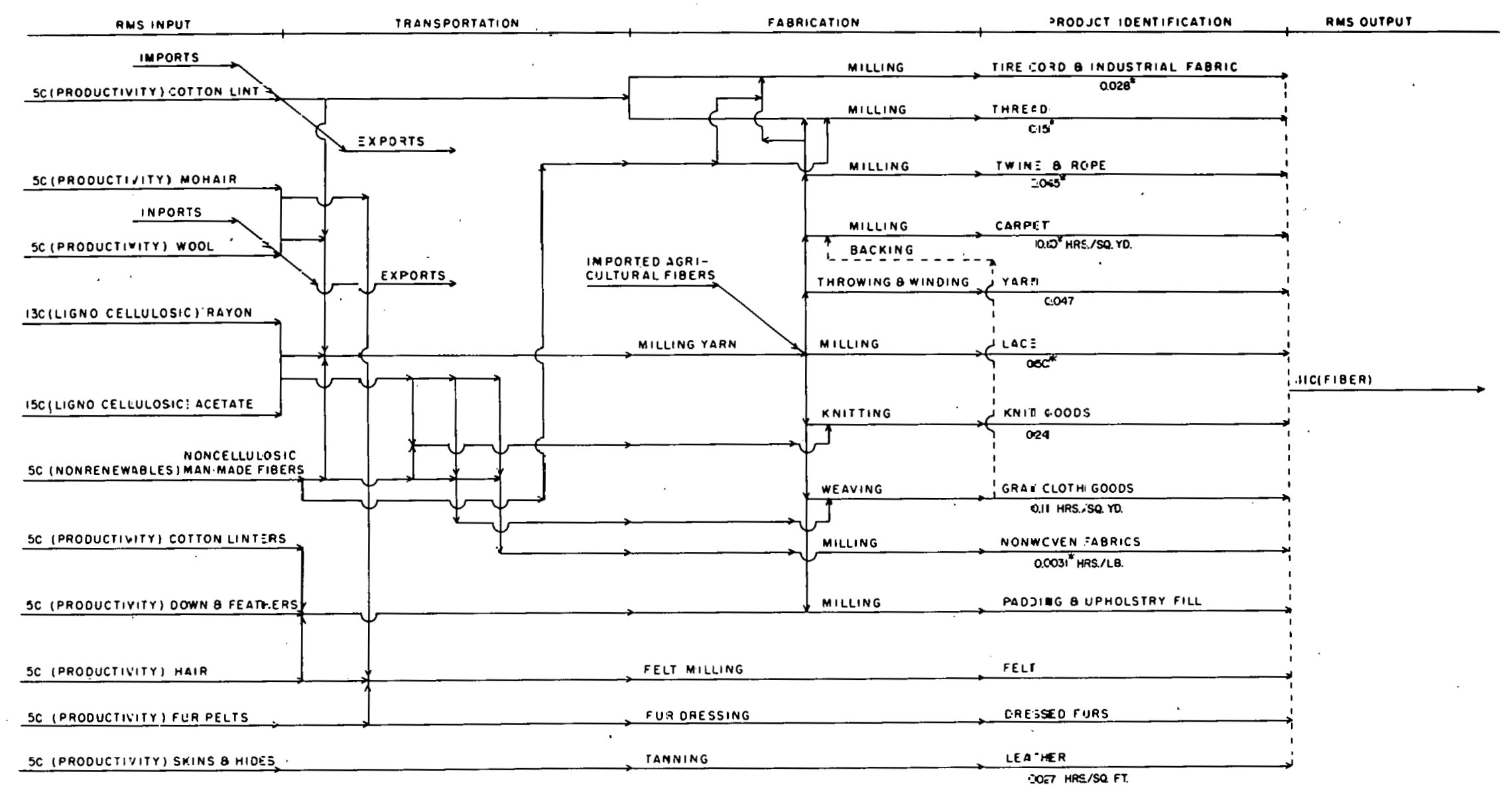

NOTES: (i) RMS INPUTS AND OUT JUTS IDENTIFY tHE FIGURE NUMBERS ALONG WITH SECTORS IN PARENTHESES, FROM ANO INTO WHICH THE MATERIAL FLOWS TAKE PLACE, RESPECTIVEL

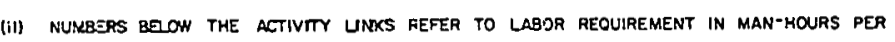

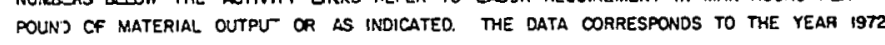

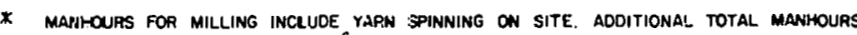
FOR MARN MILLS EOUAL $193 \times$ Do

Figure 10C. Reference material system. Fibers (textiles $\&$ apparel) sector III. 


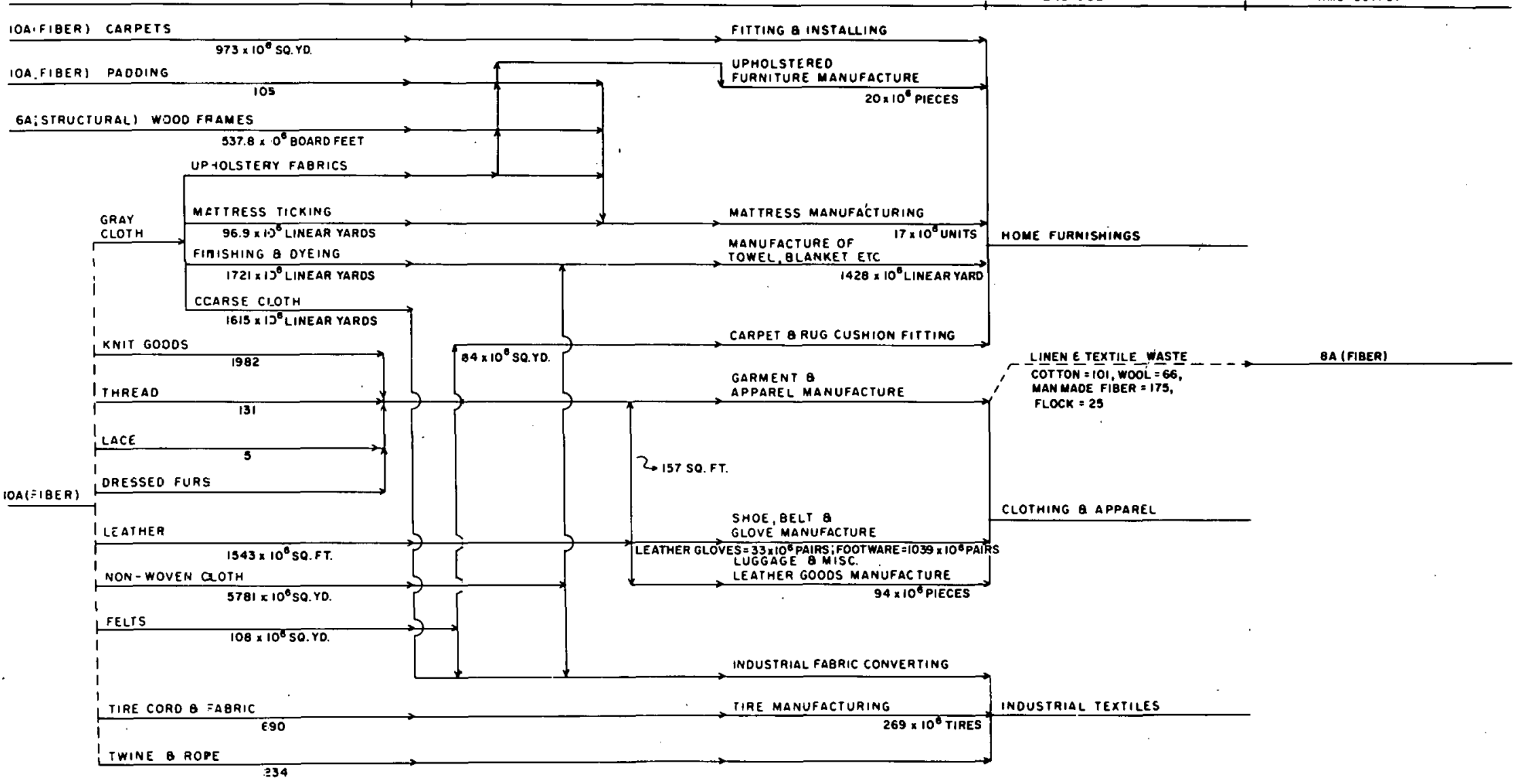
NOTES: (i) RMS INPUTS ANO OUTPUTS IOENTIFY THE FIGURE NUMAERS ALONG WITH SECTORS IN
PARENTHESES, FROM AND INTO WHICH THE MATERIAL FLOWS TAKE PLACE, RESPECTIVELY. (ii) THE NUMBERS BELOW ACTIVITY LINKS REFER TO MATERIAL FLOWS IN MILLION POUNDS,
OR AS IND:CATED, FOR THE YEAR 1972

Figure 11A. Reference material system. Fibers (textiles \& appare1) sector IV. 


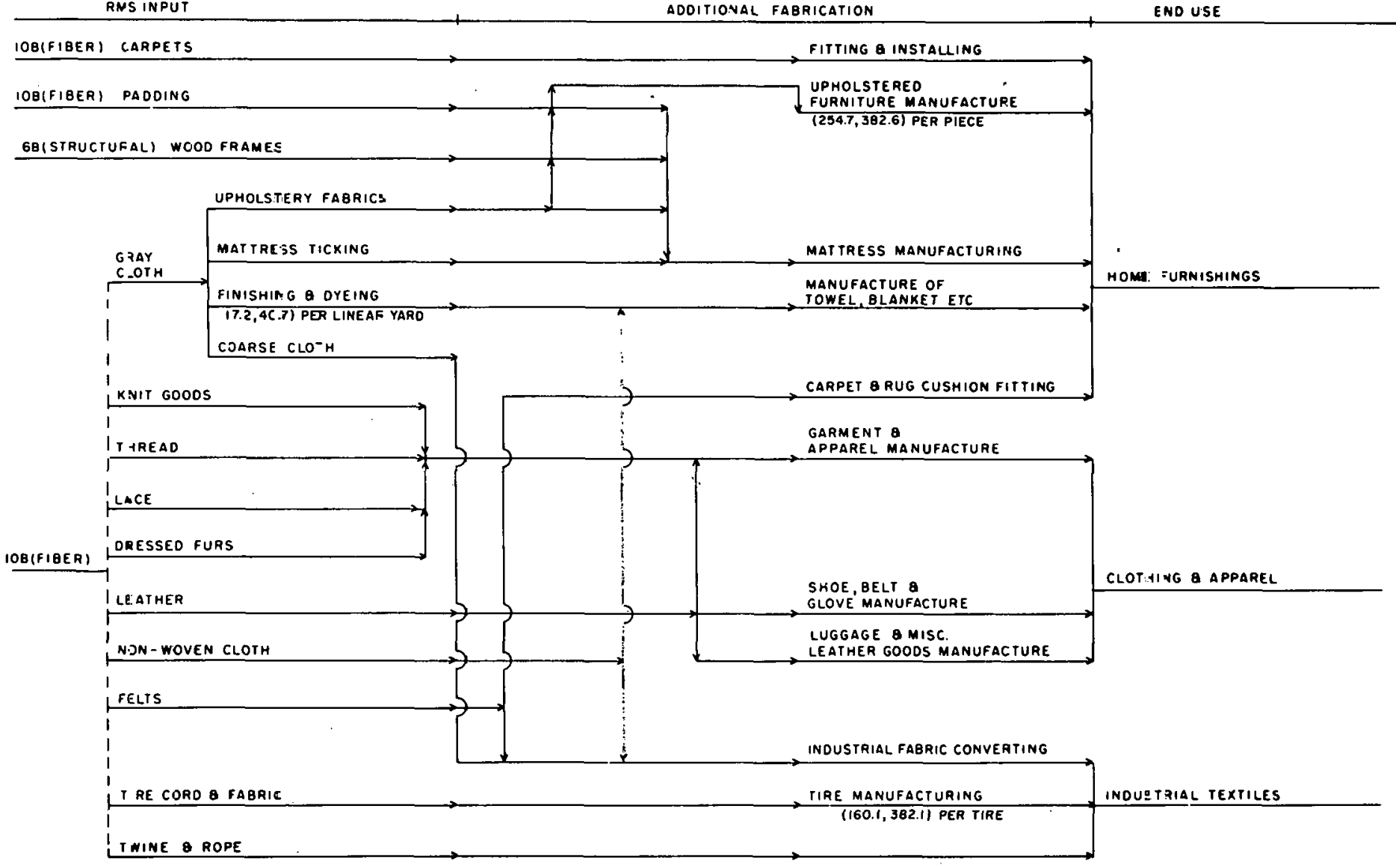

NOTES: (i) RMS INPUTS AYO O-TPUTS IOENTIFY THE FIGURE NUMAERS ALONG WITH SECTORS N

(1.) TWO NUMBERS IN PARENTHESES BELOW THE ACTIVITY LINKS REFER TO ELLECTRICAL $B$ TOTAL ENERGY REQUIRENENT RESPECTIVELY, IN THOUSANO B TU THERMAL PER POUND OF MATERIAL OUTPUT OR AS NOICATED. THE OATA CORRESPONDS TO THE YEAR IS72

Figure 11B. Reference material system. Fibers (textiles \& afparel) sector IV. 


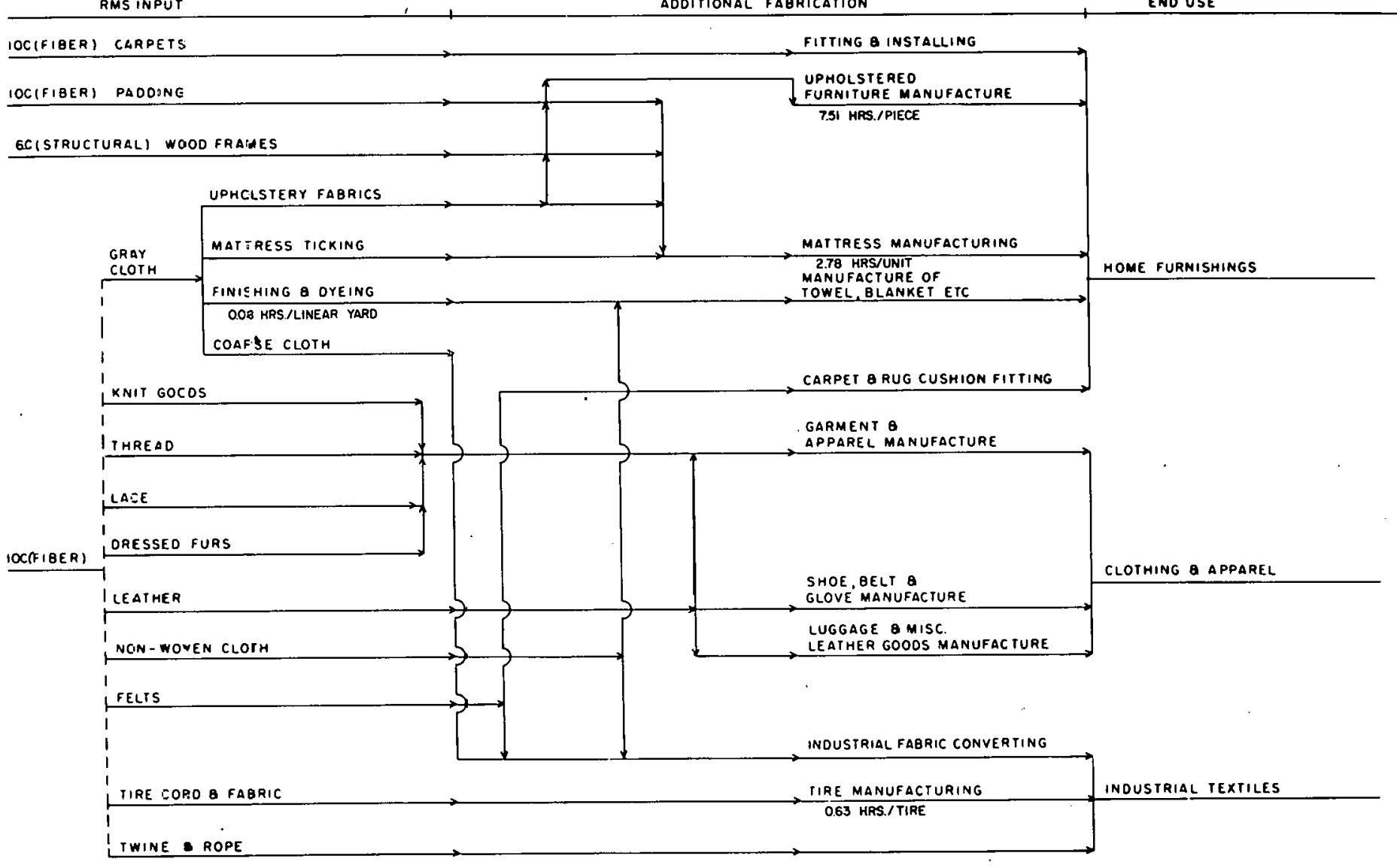

NOtES: (i) RNS INPUTS AND OUTPUTS IDENTIFY THE FIGURE NUMOERS ALONG WITH SECTORS IN
PARENTHESES, FROM ANO INTO WHICH THE MATERIAL FLOWS. TAKE PLACE, RESPECTIVELY

(ii) NUMBEFS beLOW THE ACTIVITY LINKS REFER tO LABOR REOUIREMENT IN THE UNITS INDICATED. THE

DATA DORRESPONDS TO THE YEAR 1972

Figure 11C. Reference material system. Fibers (textiles \& apparel) sector IV. 


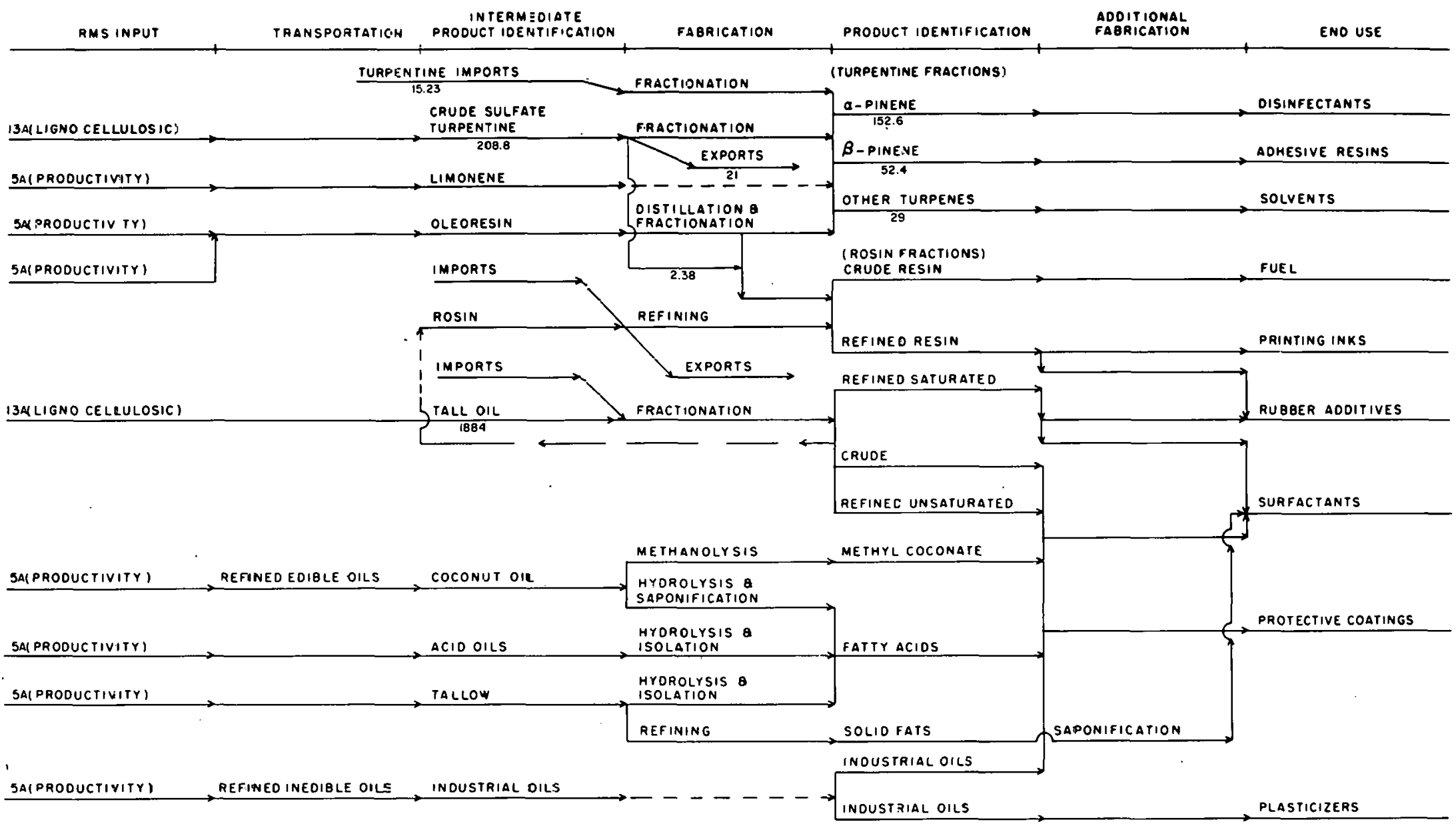

NOTES: (a) RMS INPUTS NND OUTPUTS IDENTIFY THE FIGURE NUMBERS ALONG WITH SECTORS IN

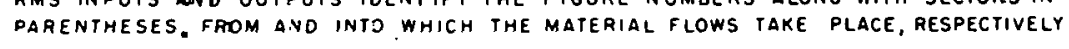
(:) THE NUMEERS BELOW ACTIVITY LINKS REFER TO MATERIAL FLOWS IN MILLION POUNOS,

Figure I2A. Reference material system. Extractives. 


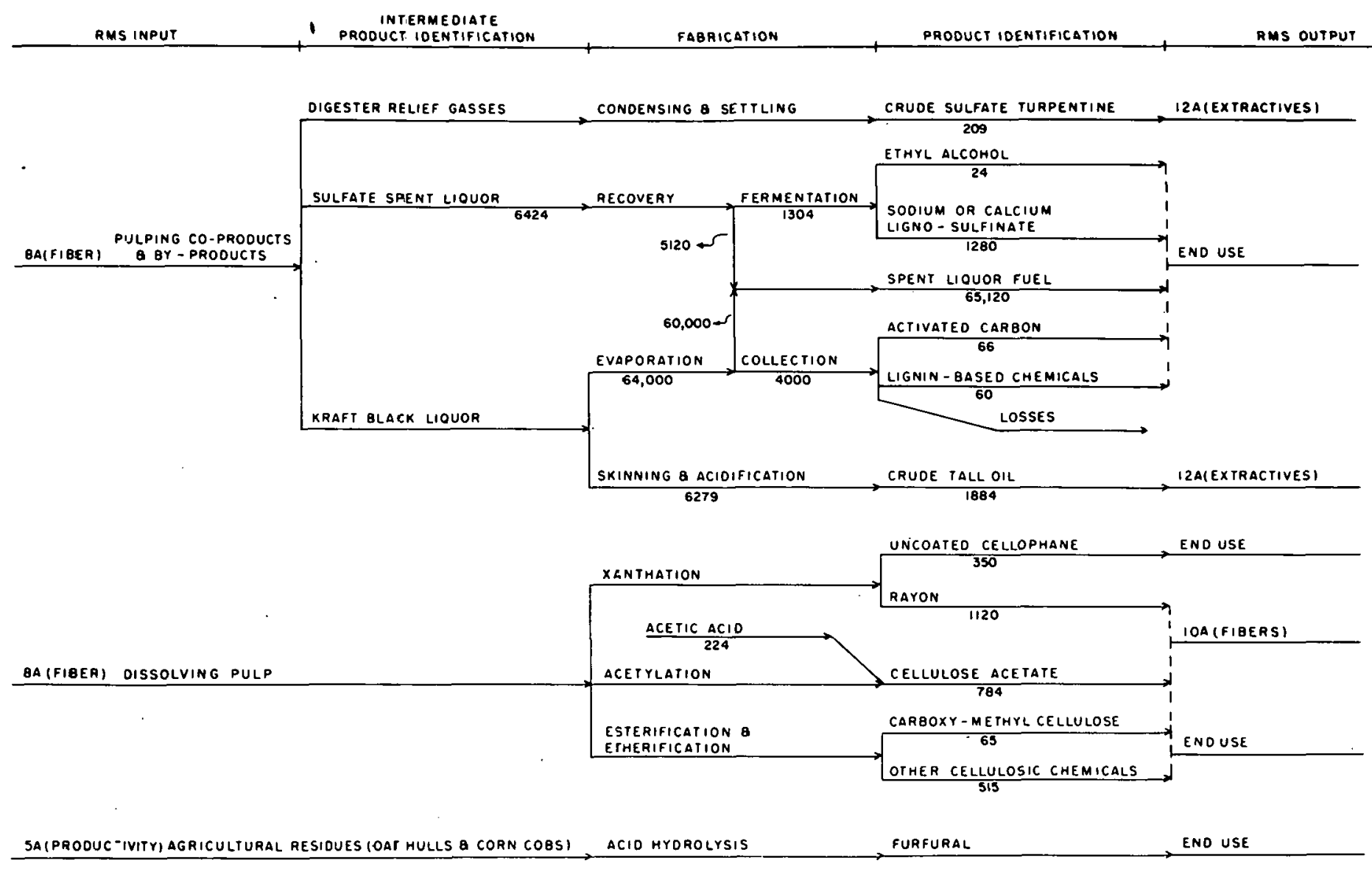

NOTES: (i) RMS. INPUTS AND OUTPUTS DENTIFY THE FIGURE NUMBERS ALONG WITH SECTORS IN

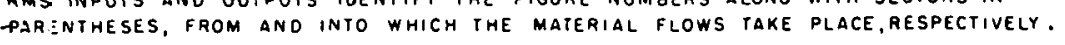

(ii) FHE NUMBERS BELOW ACTIVITY LINKS REFER TO MATERIAL FLOWS IN MILLION POUNOS, OF THE YEAR 1972

Figure 13A. Reference material system. Fibers V \& Ligno cellulosic sector. 


\begin{tabular}{|c|c|c|c|c|c|c|c|c|c|}
\hline Resource & $\begin{array}{l}\text { Procuction } \\
\text { (Grawing) }\end{array}$ & $\begin{array}{l}\text { Harvesting } \\
\text { or } \\
\text { Extraction }\end{array}$ & Processing & $\begin{array}{c}\text { Transportation } \\
\text { (Aggregate) }\end{array}$ & $\begin{array}{l}\text { Intermed late } \\
\text { Product } \\
\text { Identification }\end{array}$ & $\begin{array}{c}\text { Pabrication } \\
\text { and } \\
\text { Recyeling } \\
\end{array}$ & $\begin{array}{l}\text { Product } \\
\text { Ident1flcation }\end{array}$ & $\begin{array}{l}\text { Additional } \\
\text { Pabrication }\end{array}$ & End Ueo \\
\hline \multirow{5}{*}{$\begin{array}{l}\text { Energy } \\
\text { Plantation } \\
\text { (7500Etu/1b) }\end{array}$} & & & & $\begin{array}{l}\text { Logg1ng } \\
\text { Res1due } \\
\text { (8500Btu/Ib) }\end{array}$ & \multirow[b]{2}{*}{ BIOMASS } & 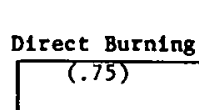 & H1-Gauge Steam & $\frac{\text { Steam Turblne }}{(.45)}$ & Electricity \\
\hline & & & & $\begin{array}{l}\text { M111 Res1due } \\
\text { (8500Btu/1b) }\end{array}$ & & $\begin{array}{c}\text { Pyrolysis } \\
(.75) \\
\text { Anaeroblc } \\
\text { Respiration } \\
\end{array}$ & $\begin{array}{c}\text { Low-Btu Gas } \\
\cdot \\
\text { Ethanol }\end{array}$ & 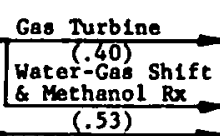 & $\begin{array}{l}\text { Methanol } \\
\text { (9600Btu//b) } \\
\text { Ethanol }\end{array}$ \\
\hline & (.96) & $(.99)$ & (1) & (1) & & $(.32)$ & & & $(12,0008 t u / 1 b)$ \\
\hline & & & Muncipai & & & Pyrolysis & Low-Btu Gas & $\begin{array}{l}\text { Water-Gas Shift } \\
\text { \& Methanlzation }\end{array}$ & \\
\hline & & & & & & $\begin{array}{c}\begin{array}{c}(.75) \\
\text { Anaerobic } \\
\text { Resplration }\end{array} \\
(.67)\end{array}$ & 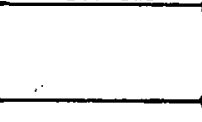 & $(.80)$ & $\begin{array}{l}\text { Synthet Ic } \\
\text { Natural Gat } \\
\begin{array}{c}(1000 \text { btu/cu } \\
\mathrm{ft})\end{array}\end{array}$ \\
\hline
\end{tabular}

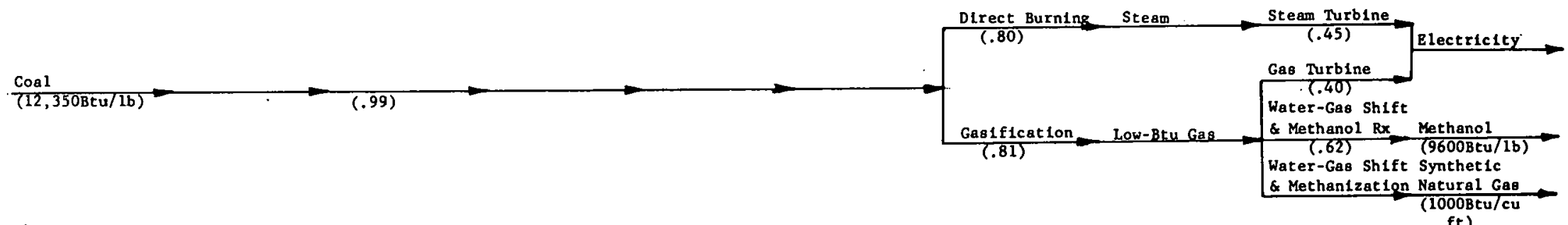

Note: Numbers belov resource or product names refer to the corresponding heating values, and the of the corres jonding processes.

- Figure 14. Reference material system. Energy from biomass conversion. 

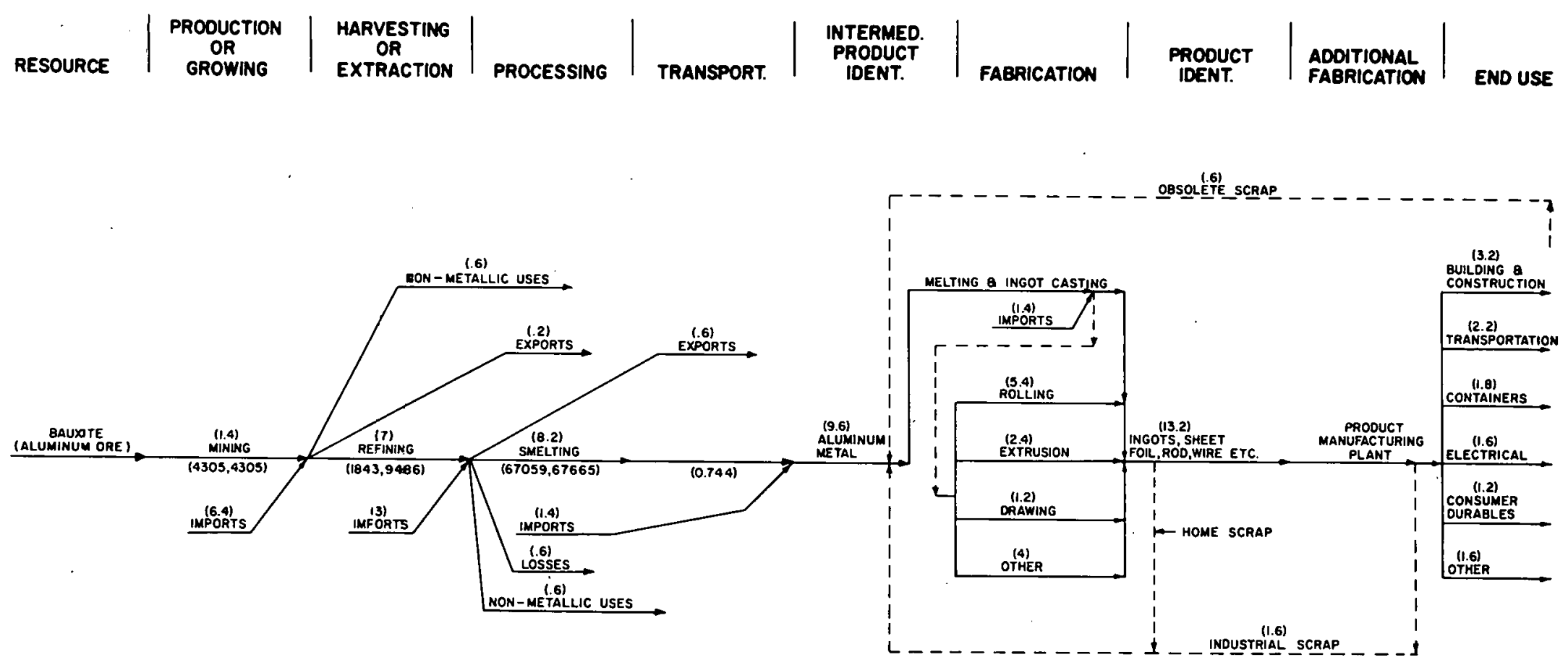

FABRICATING
MILLS

AVERAGE ENERGY CONSUMPION $-(9466,20141)$ 


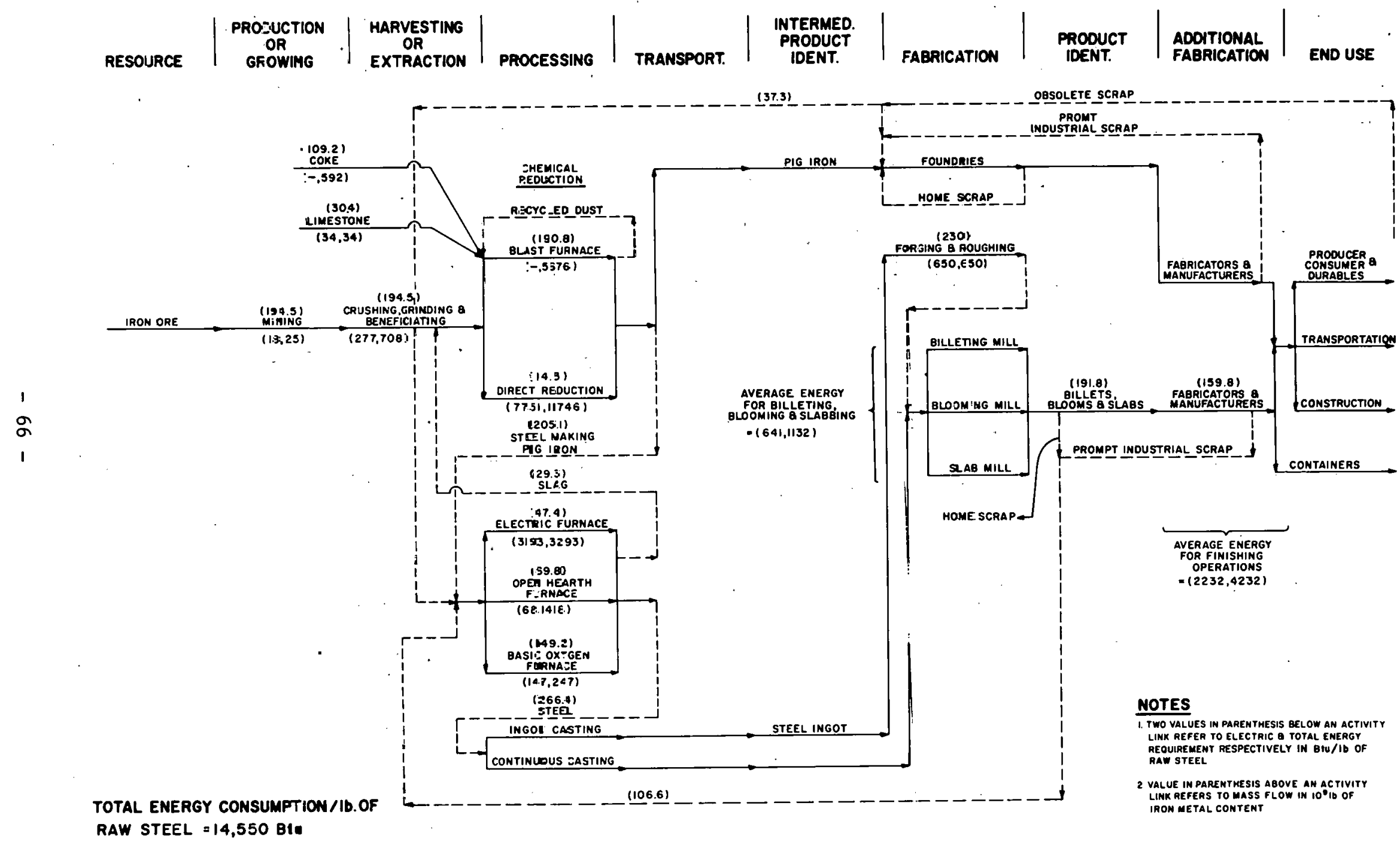

Figure 16. Refeyence material system. Iron $\&$ steel (year 1972). 


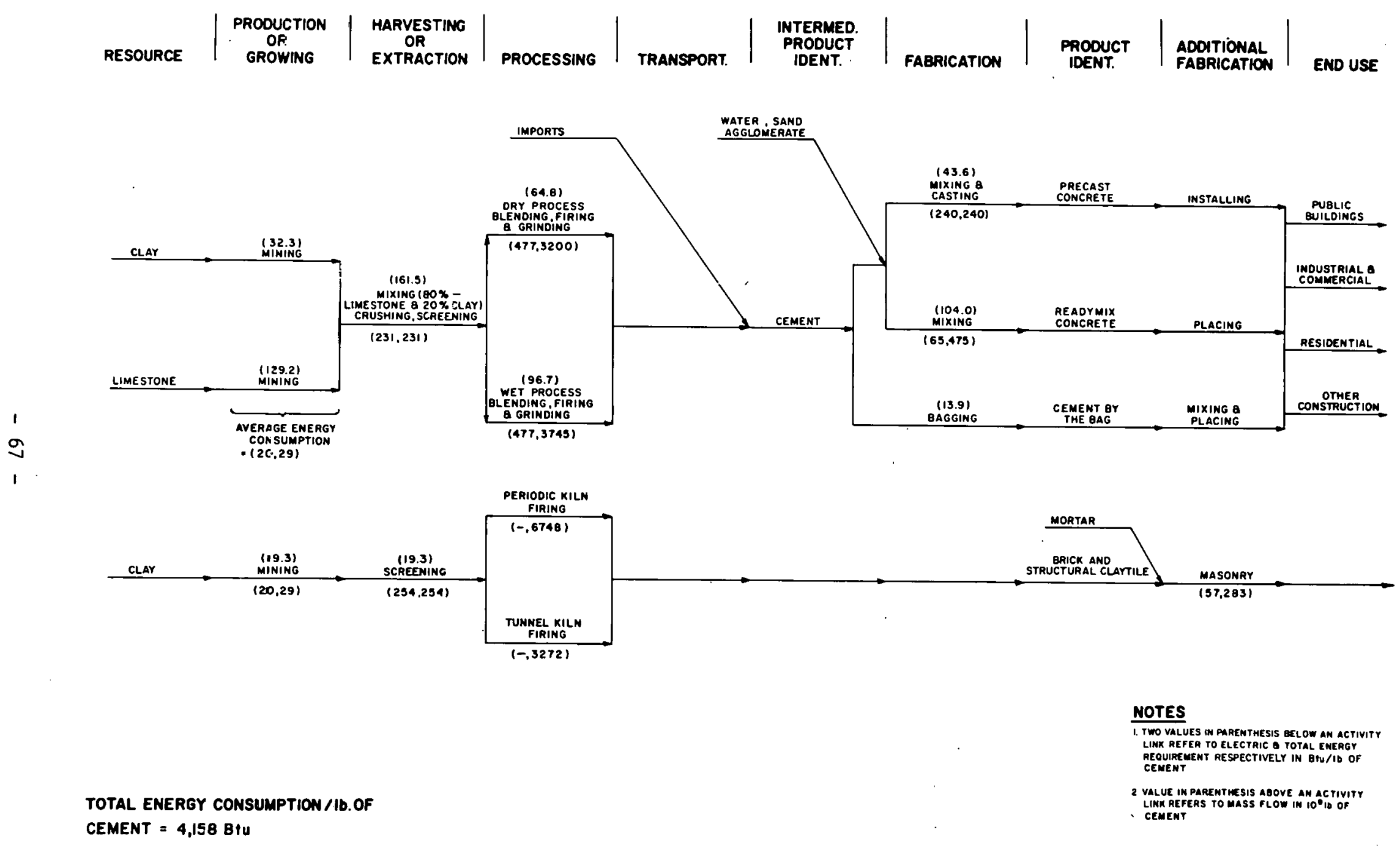

Figure 17. Reference material system. Cement \& concrete (year 1972). 


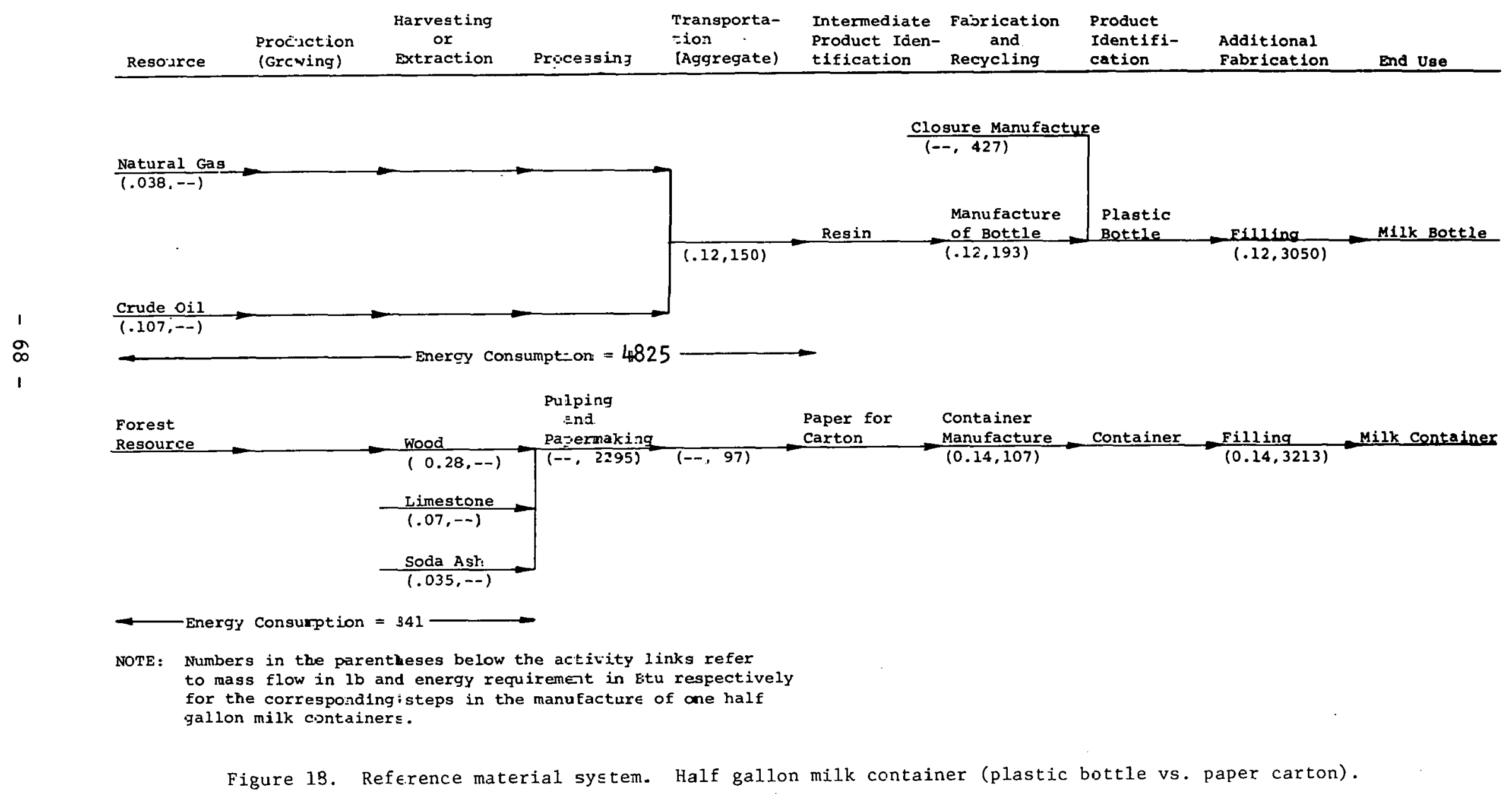




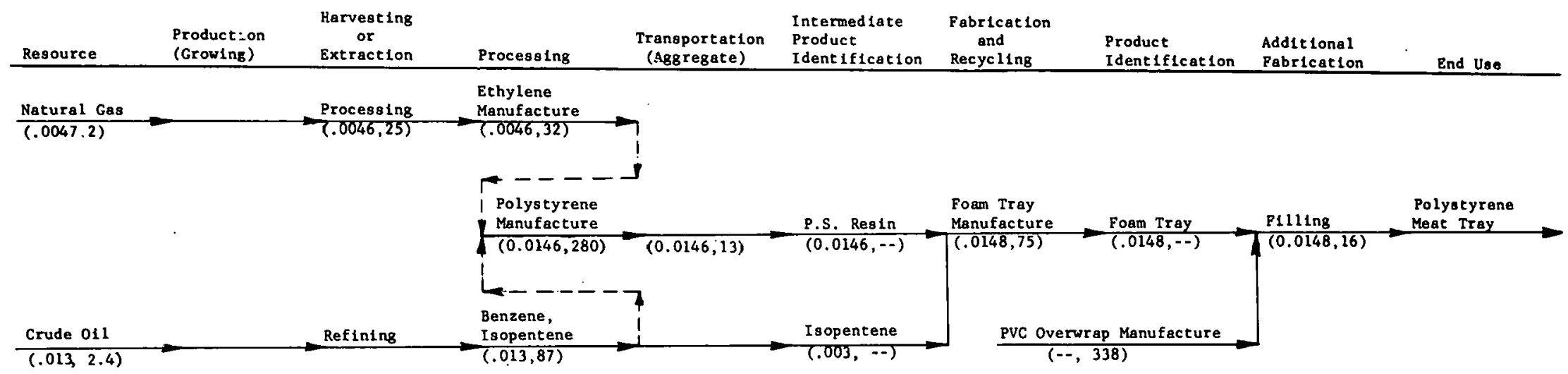

1 gำ 1

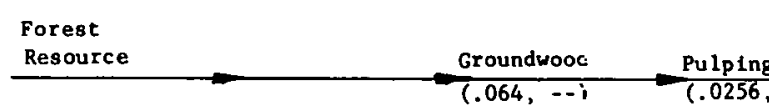

Energy Consump:ion $=16$

NOTE: Numbers in the parentheses below the activity links refer to mass flow in $1 \mathrm{~b}$. and energy requirement in Btu respectively for the corresponding steps in the manufacture of one Size 6 meat tray.

Figure 19. Reference material system. Size 6 meat tray (polystyrene vs. molded pulp).
Molded Pulp

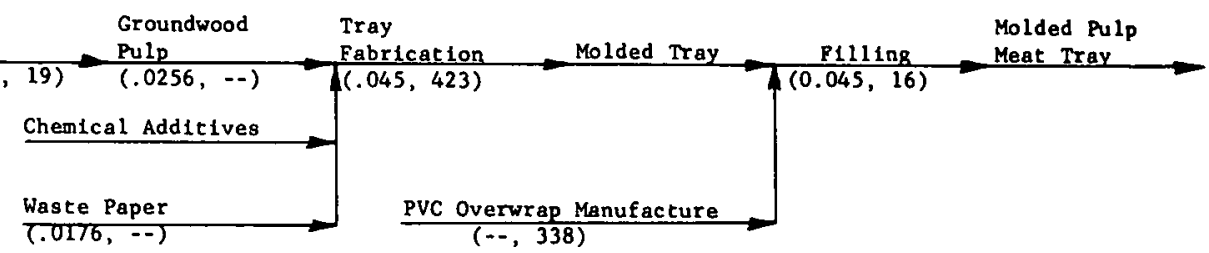

$(+-, 338)$ 